\title{
ABSTRACT \\ THE EVOLUTION OF A CHEMICALLY ZONED MAGMA CHAMBER: THE 1707 ERUPTION OF FUJI VOLCANO, JAPAN
}

\section{By Shizuko Watanabe}

The eruptive history of Fuji Volcano has been dominated by basaltic volcanism. However, the 1707 eruption of Fuji Volcano resulted in a chemically zoned volcanic deposit ranging from basalt to dacite. Explosive, silicic eruptions such as this have occurred only twice in the history of Fuji Volcano, in 2800BP and in 1707AD, and the processes responsible for generating siliceous magmas beneath Fuji Volcano are not well understood.

Detailed petrographic, major and trace element, and $\mathrm{Sr}, \mathrm{Nd}, \mathrm{Pb}$, and $\mathrm{Os}$ isotope studies were done in order to constrain the petrogenetic processes that formed a chemically zoned magma chamber prior to the 1707 eruption of Fuji Volcano. Kawamoto (1992) proposed that liquid immiscibility played a major role; however, this study shows that the chemical variations in the Fuji 1707 deposit can be explained by fractional crystallization of the observed mineral assemblage accompanied by minor crustal contamination. 


\title{
THE EVOLUTION OF A CHEMICALLY ZONED MAGMA CHAMBER: \\ THE 1707 ERUPTION OF FUJI VOLCANO, JAPAN
}

\author{
A Thesis \\ Submitted to the \\ Faculty of Miami University \\ in partial fulfillment of \\ the requirements for the degree of \\ Master of Science \\ Department of Geology \\ by \\ Shizuko Watanabe \\ Miami University \\ Oxford, OH 45056 \\ 2003
}

Advisor

Dr. Elisabeth Widom

Reader

Dr. William K. Hart 


\section{Table of Contents}

Title $\quad$ i

Table of Contents ii

List of Figures $\quad$ iv

List of Tables vi vi

Acknowledgements viii

Chapter 1: Introduction to Fuji Volcano

Introduction 1

Geological setting of Fuji Volcano 1

History of Fuji Volcano 4

$\begin{array}{ll}\text { The Fuji } 1707 \text { eruption } & 14\end{array}$

$\begin{array}{ll}\text { Summary } & 20\end{array}$

Chapter 2: $\quad$ Introduction to chemically zoned magma chambers

$\begin{array}{ll}\text { Introduction } & 27\end{array}$

$\begin{array}{lr}\text { Case studies } & 28\end{array}$

Liquid immiscibility 36

$\begin{array}{ll}\text { Objective of this study } & 39\end{array}$

Chapter 3: The Evolution of a Chemically Zoned Magma Chamber: the 1707 Eruption of Fuji Volcano, Japan

$\begin{array}{lr}\text { Abstract } & 40 \\ \text { Introduction } & 41 \\ \text { Geological setting/background } & 42 \\ \text { Analytical techniques } & 42 \\ \text { Results } & 43 \\ \text { Discussion } & 47 \\ \text { Conclusions } & 51 \\ \text { Figures } & 53\end{array}$


References

Appendix

1. The 1707 Fuji sample processing procedures.

92

2. Major and trace element variations of the Fuji 1707 deposit. 94

3. Mineral chemistry of the Fuji 1707 deposit. 99

4. Photomicrographs of the Fuji 1707 samples. 103 


\section{List of Figures}

\section{Chapter 1:}

Fig. 1.

Fig. 2.

Fig. 3.

Fig. 4.

Fig. 5.

Fig. 6.

Fig. 7. Relationship between altitude of eruptive centers and whole rock chemistry (modified after Takahashi et al., 1991).

Fig. 8. Cartoon diagram of craters of the 1707 eruption (modified after Aihara, 2003).

Fig. 9. $\quad$ Stratigraphy of the Fuji 1707 deposit (modified after Miyaji, 1984).

Fig. 10. Stratigraphy of the Fuji 1707 deposit (modified after Nakamura et al., 1986).

Fig. 11. Major element variations of the Fuji 1707 deposit (modified after Nakamura et al., 1986).

Fig. 12. Trace element variations of the Fuji 1707 deposit (modified after Nakamura et al., 1986).

\section{Chapter 2:}

Fig. 1. Schematic models of ${ }^{87} \mathrm{Sr} /{ }^{86} \mathrm{Sr}$ versus ${ }^{87} \mathrm{Rb} /{ }^{86} \mathrm{Sr}$ for three different processes that form distinct trends (modified after Wolff et al., 1999).

Fig. 2. $\quad \mathrm{Pb}$ isotope ratios of single sanidines for Guaje unit $\mathrm{A}$, Upper Guaje, and ignimbrite, and glomerocrysts (modified after Wolff and Ramos, 2003).

Fig. 3. $\mathrm{TiO}_{2}$ and $\mathrm{P}_{2} \mathrm{O}_{5}$ versus $\mathrm{SiO}_{2}$ for the Fuji 1707 samples (modified after Kawamoto, 1990).

Fig. 4. Proposed liquid immiscibility model for the Fuji 1707 deposit (modified after Kawamoto, 1992). 
Fig. 5. Petrographic evidence for liquid immiscibility in an olivine basalt from the 864AD deposit of Fuji Volcano (modified after Fujii et al., 1980).

\section{Chapter 3:}

Fig. 1. Plate tectonic framework of Japan (modified after Taira, 2001)

Fig. 2. Photograph of sampling site.

Fig. 3. Alkali versus silica classification diagram (after LeBas et al., 1986).

Fig. 4. Variation in $\mathrm{CaO}(\mathrm{wt} \%)$ and $\mathrm{Sr}$ concentration $(\mathrm{ppm})$ versus relative depth in the Fuji 1707 deposit at the second sampling site.

Fig. 5. Chondrite-normalized REE patterns for the Fuji 1707 deposit.

Fig. 6. Petrographic evidence of disequilibrium textures in plagioclase and olivine phenocrysts.

Fig. 7. Feldspar chemical compositions.

Fig. 8. $\quad \mathrm{Sr}, \mathrm{Nd}$, and $\mathrm{Pb}$ isotopic compositions of juvenile and crustal xenolith samples from the Fuji 1707 deposit.

Fig. 9. Os isotopic compositions of representative samples from the Fuji 1707 deposit.

Fig. 10. Major element variation diagrams with modeling results.

Fig. 11. $\quad \mathrm{P}_{2} \mathrm{O}_{5}$ versus $\mathrm{SiO}_{2}$ for the Fuji 1707 deposit.

Fig. 12. Trace element variation diagrams with modeling results.

Fig. 13. Chondrite normalized REE patterns with modeling results.

Fig. 14. Cartoon diagram of the evolution of the Fuji 1707 chemically zoned magma chamber. 


\section{List of Tables}

\section{Chapter 1:}

Table 1. Classification of Fuji tephra (modified after Machida, 1967).

Table 2. Whole rock chemistry of Fuji Volcano (modified after Takahashi et al., 1991).

Table 3. Summary of historical eruptions of Fuji Volcano (data compiled from Tsuya, 1995, 1968; Machida, 1981; Koyama, 1998).

Table 4. Description of the Fuji 1707 eruption (modified after the Weather Observatory, 2001).

Table 5. Summary of the Fuji 1707 eruption of tephra (modified after the Weather Observatory, 2001).

Table 6. Major element concentrations of the Fuji 1707 deposit (modified after Nakamura et al., 1986).

Table 7. Trace element concentrations of the Fuji 1707 deposit (modified after Nakamura et al., 1986).

\section{Chapter 2:}

Table 1. Summary of common petrogenetic processes and their indicators.

\section{Chapter 3:}

Table 1. Major and trace element concentrations for juvenile and xenolith samples from the Fuji 1707 deposit.

Table 2. Rare earth element concentrations for representative juvenile samples from the Fuji 1707 deposit.

Table 3. Average chemical compositions of phenocrysts from the 1707 Fuji deposit.

Table 4. $\quad \mathrm{Sr}, \mathrm{Nd}$, and $\mathrm{Pb}$ isotopic compositions of representative juvenile and xenolith samples from the Fuji 1707 deposit.

Table 5. Os isotopic compositions and concentrations of representative juvenile samples from the Fuji 1707 deposit.

Table 6. Fractionating assemblages with relative mineral proportions and percentage of fractionation. 
Table $7 . \quad$ Results of major element modeling.

Table 8. Results of trace element modeling. 


\section{Acknowledgements}

This thesis could not have been completed without generous assistance from some important individuals. First of all, I would like to express my appreciation to my advisor Dr. Elisabeth Widom. She is an excellent professor who gave me her dedication and time commitment to guide me through my thesis. I am very thankful that she took an interest in Japanese volcanism on top of her numerous ongoing research projects elsewhere. I am very fortunate to be able to continue my PhD work with her. My sincere appreciation goes to Dr. Tadahide Ui of Hokkaido University. Without his generous assistance since my undergraduate days, I would not have studied volcanoes in graduate school. I thank him for introducing me to the project on Fuji Volcano and for the continuous support with which he has been providing me.

I am grateful to Dr. William K. Hart of Miami University for reading my thesis, Dr. Naomichi Miyaji of Nihon University and Dr. Arata Sugimura for assistance with sampling, Dr. John Morton of Miami University for laboratory assistance, Dr. John Rakovan of Miami University for assistance with cathodoluminescence analyses, and Mr. Dave Kuentz of Miami University for assistance with editing the manuscript. I thank Alicia Roberts for her work on Os isotope analyses. I would also like to thank Ninad Bondre, Darin Snyder and Matt Brueseke for their assistance on my project. And last but not least, I would like to thank my parents Masatoshi and Motoko Watanabe for their love and support.

Financial support was provided by NSF EAR 020759 and EAR-MRI 0116033 (to EW), and grants from the Geological Society of America 7303-02 and Sigma Xi (to SW). In addition, two round-trip tickets to Japan in 2001 and in 2002 were provided by Weastec Inc., Hillsboro, OH. Abstract submission and registration fees for Goldschmidt 2003 in Kurashiki, Japan were granted by a Goldschmidt Student Grant from the Geochemical Society. 


\section{Chapter 1}

\section{Introduction to Fuji Volcano}

\section{Introduction}

Fuji Volcano is a nearly symmetrical stratovolcano, which often appears in pictures and photographs as a symbol of Japan. It is the highest mountain in Japan with an elevation of 3776 $\mathrm{m}$ and a volume of approximately $1400 \mathrm{~km}^{3}$, located in south-central Honshu. It has been active since its formation in the late Pleistocene. The eruptive history has been dominated by basaltic volcanism; however, silicic eruptions have occurred twice, in 2800BP and in 1707AD. Although Fuji Volcano has been dormant for almost 300 years since the last eruption in 1707, increased seismic activity has been detected since the fall of 2000 (Asahi, 2001). Japan has one of the highest population densities and highest number of active volcanoes in the world; therefore, understanding the history of the volcanoes as well as the eruptive mechanism is essential to facilitate public safety in case of a large explosive eruption. The purpose of this chapter is to provide the geologic background to Fuji Volcano.

\section{Geological setting of Fuji Volcano}

Japan is an island arc located in the western Pacific, which is characterized by a linear chain of islands with frequent earthquakes and volcanic eruptions. Japan was originally part of the Eurasian continental margin (Ogawa et al., 1997) and the present day arc system began in the Neogene (Taira, 2001). The four main islands of Japan are, from north to south respectively Hokkaido, Honshu, Shikoku and Kyushu. The complicated arc-trench system of Japan is related to the Kuril, Honshu, Ryukyu, and Izu-Bonin (Ogasawara) arcs (fig. 1; Aramaki and Ui, 1982; Taira, 2001), and involves five plates: the Eurasia, Amur, Okhotsk, Pacific, and Philippine Sea plates. Fossa Magna is a weakly developed collisional zone (Ogawa et al., 1997) formed during the Miocene (Tsuya, 1968; Machida, 1981) located in central Honshu (fig. 1). Many quaternary volcanoes (fig. 2) are associated with Fossa Magna, and comprise the Fuji Volcanic Zone named after Fuji Volcano (Tsuya, 1968; Machida, 1981). Fuji Volcano is located in 


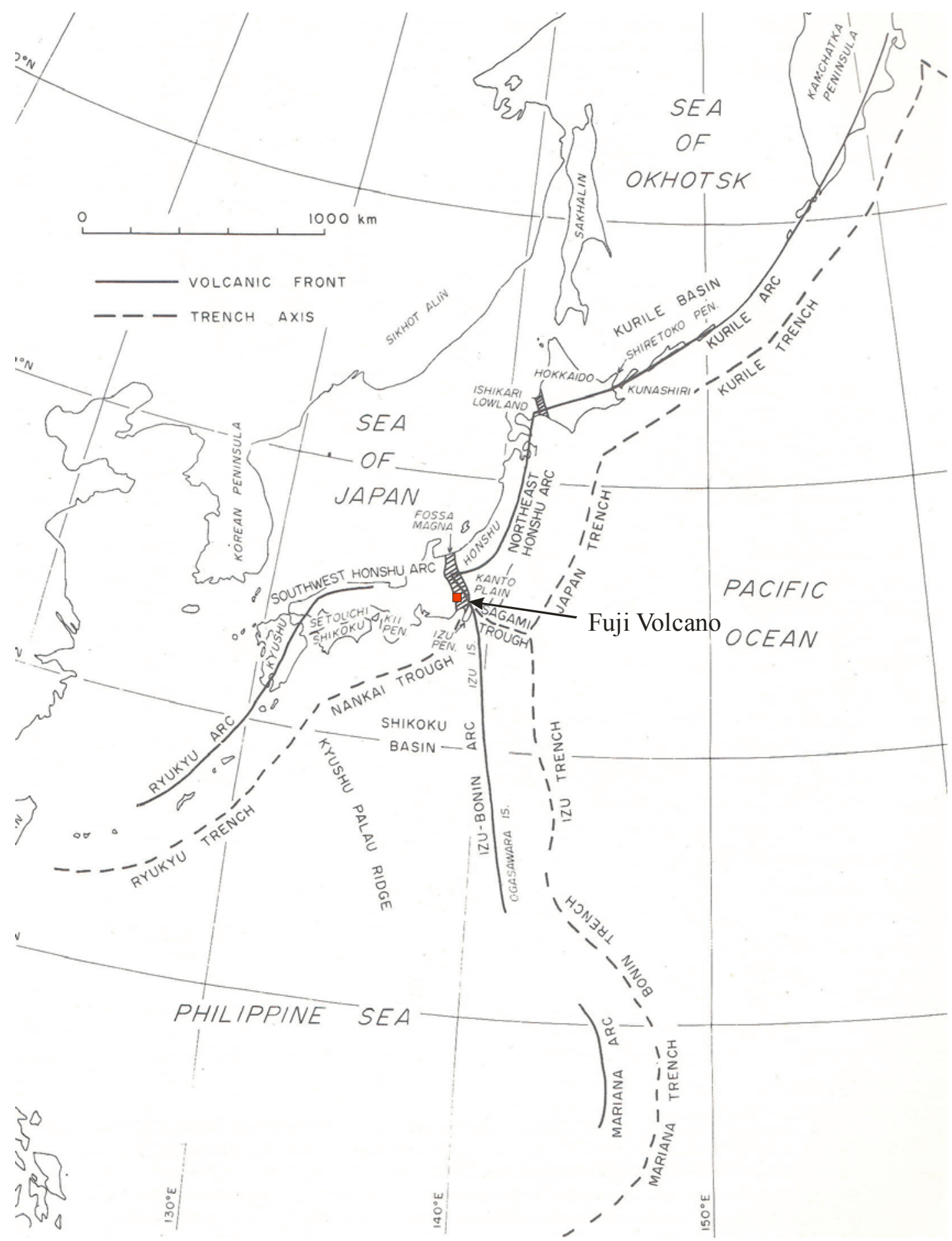

Fig. 1. Arc-trench system of Japan (modified after Aramaki and Ui, 1982). Three chains of island arcs (North-east Honshu-Kurile, Izu-Bonin-Mariana, and Southwest Honshu-Ryukyu) meet in central Honshu (Aramake and Ui, 1982). The shaded area shown is the Fossa Magna. Fuji Volcano ( $\square$ ) is located in south Fossa Magna. 


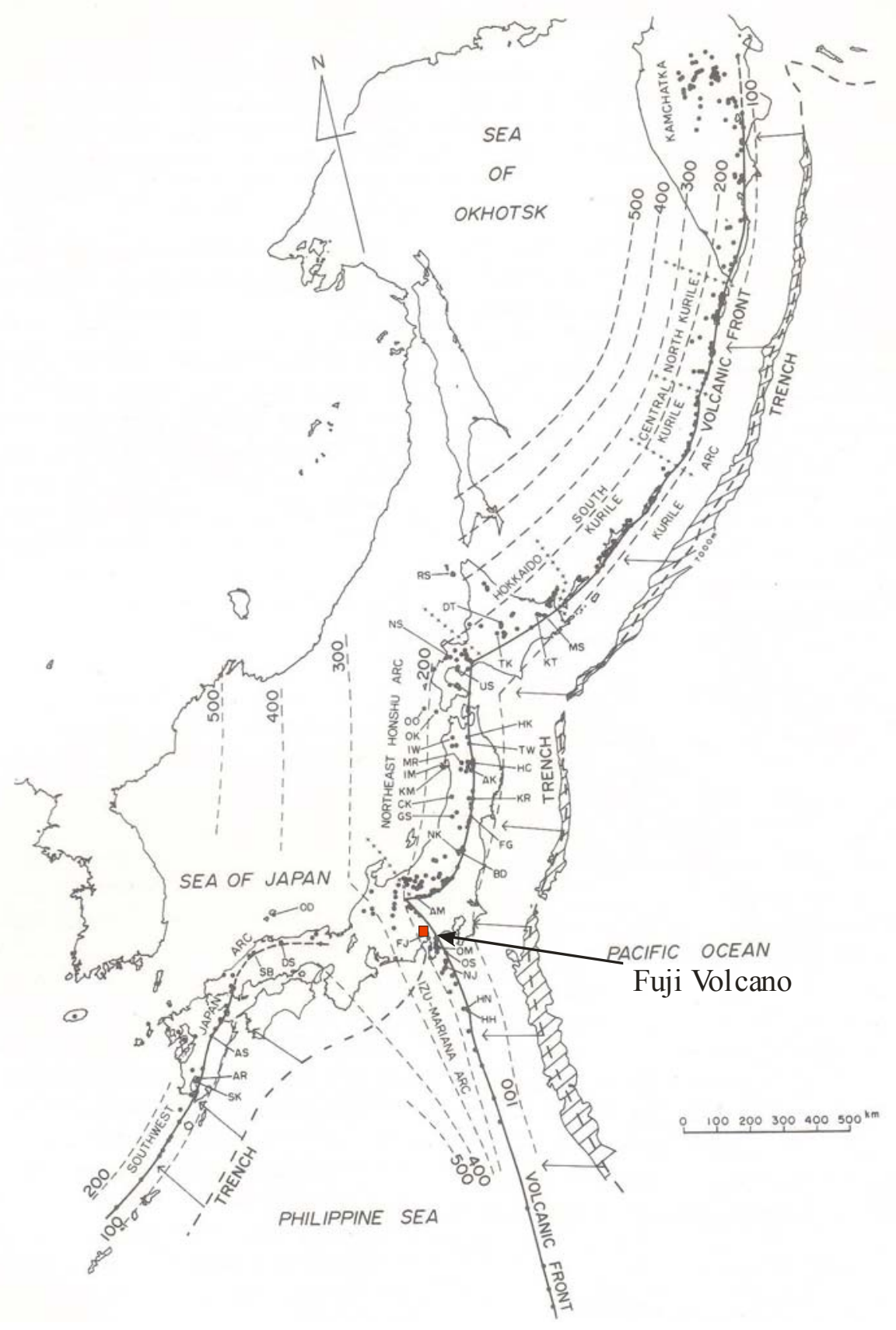

Fig. 2. Quaternary volcanoes $(\bullet)$ and their relationship to the volcanic front (modified after Aramaki and Ui, 1982). Fuji Volcano is shown in red square ( $\square)$.

south-central Honshu, in the southern part of Fossa Magna, lying over the westward-subducting Pacific Plate at 130 to $150 \mathrm{~km}$ depth and possibly influenced by the northward-subducting Philippine Sea plate at $30 \mathrm{~km}$ depth (Arculus et al., 1991). 


\section{History of Fuji Volcano}

Fuji Volcano is a relatively young volcano, which was formed around 80,000 years ago. Three distinct volcanoes including Komitake, Older Fuji, and Younger Fuji have been recognized, and make up the main edifice of the present Fuji Volcano (fig. 3). The basement rocks belong to the Misaka and Fujikawa groups, which consist of Tertiary marine sediments and volcanic rocks such as green tuffs (Miyaji, 1990). Due to the complicated growth history of the volcano, several classifications have been made. Tsuya (1940) of the former Earthquake Research Institute, who studied Fuji Volcano the most extensively in the past, divided the post-Komitake eruptions into Older Fuji and Younger Fuji based on the geology and petrology of lava flow and mudflow deposits. Miyaji $(1988,1990)$ recognized six periods of mudflow deposits within Older Fuji Volcano, while he subdivided Younger Fuji Volcano into six periods based on tephrostratigraphy combined with Carbon-14 dating. Machida (1967) divided the history of Fuji Volcano into three periods of Old Fuji I (80,000-10,000BP), Old Fuji II (10,000-8,000BP), and Younger Fuji (5,000BP-Present) based on tephrochronology. Fuji Volcano experienced quiescence between Old Fuji II and Younger Fuji, as evidenced by the formation of the Fuji Black humic ash layer between Old Fuji II and Younger Fuji (Machida, 1967).

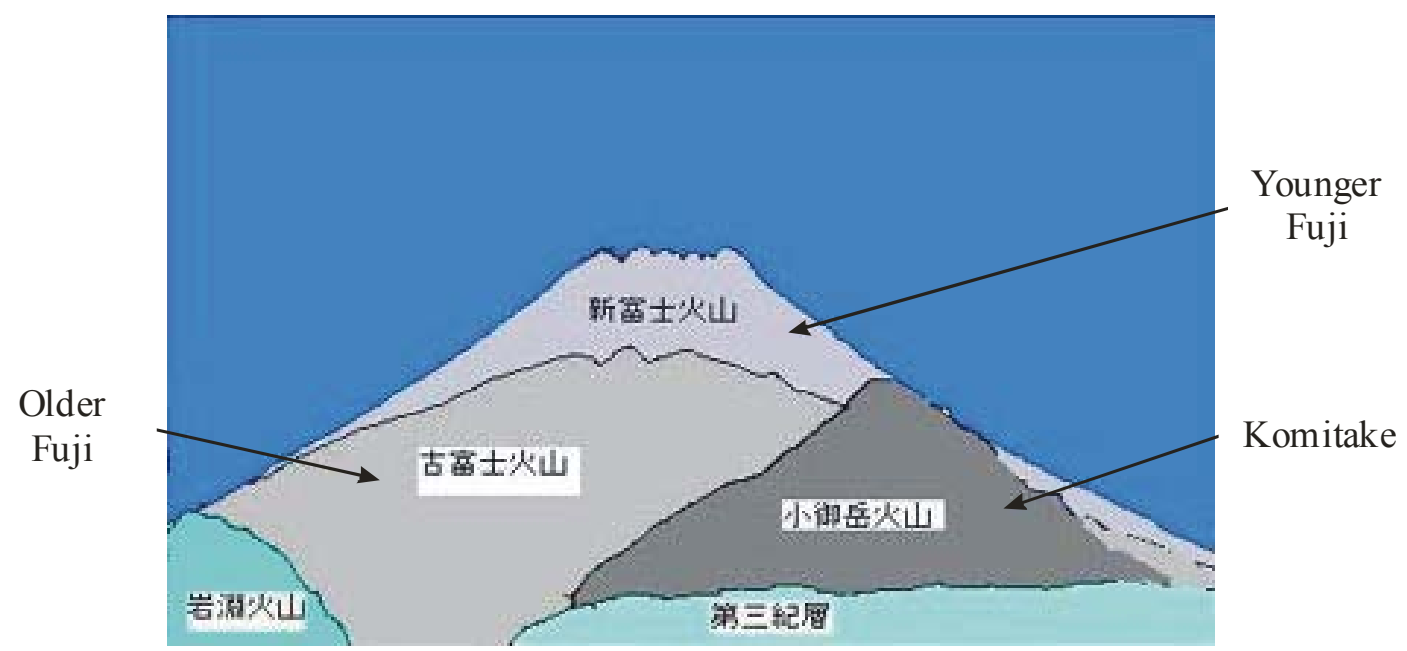

Fig. 3. Cartoon diagram of Fuji Volcano (modified after Aihara, 2003). Three distinct volcanoes including Komitake, Older Fuji, and Younger Fuji make up the main edifice of the present Fuji Volcano. 


\section{Komitake Volcano}

The oldest part of Fuji Volcano, Komitake Volcano (fig. 3) is located in the northern flank. A detailed history of Komitake Volcano is poorly understood due to the fact that it is buried underneath Older Fuji Volcano and Younger Fuji Volcano. Komitake Volcano is an andesitic stratovolcano with a summit crater. The elevation is approximately $2300 \mathrm{~m}$.

The petrology and chemistry of the volcano are known to be similar to Ashitaka Volcano, a late Pleistocene volcano located to the south of Fuji Volcano, which mainly erupted olivinebearing two pyroxene-andesite (Tsuya, 1968; Machida, 1981).

\section{Older Fuji Volcano}

Older Fuji volcano (fig. 3) began its activity on the southern flank of Komitake Volcano around 80,000 years ago. The degree of erosion as well as the length of the quiescent period after Komitake Volcano are still poorly understood. Tsuya (1968) differentiated Older Fuji Volcano from Younger Fuji Volcano based on several field observations. These observations include: 1) evidence of fault movement during or shortly after the eruption of Older Fuji; 2) all of the Older Fuji eruptive materials lie underneath those of Younger Fuji Volcano; 3) cemented mud flow deposits of Older Fuji are distinguishable from the porous deposits of Younger Fuji.

Eruptive products of Old Fuji Volcano include abundant tephra as well as basaltic lava and pyroclastic flows (Machida and Moriyama, 1968). These eruptions triggered large-scale mudflows later named Old Fuji mudflows. Miyaji (1990) recognized six different periods of mudflows: 1) 50,000 BP and older; 2) 50,000 BP; 3) 50,000-19,000 BP; 4) 19,000-18,000 BP; 5) 16,000 BP; and 5) 15,000-12,000 BP. The mudflow deposits are composed of several different types of basalts including aphyric basalt, olivine basalt, augite-olivine-basalt, hyperstheneaugite-olivine-basalt, and hypersthene-olivine-basalt as well as xenolith rock fragments (Tsuya, 1968; Machida, 1981).

\section{Younger Fuji Volcano}

The eruptions of Younger Fuji Volcano (fig. 3) started near or on top of Older Fuji Volcano's summit around 11,000 years ago. Tsuya (1968) divided the eruptive materials of Younger Fuji Volcano into three units: 1) older ejecta; 2) middle ejecta; and 3) younger ejecta. This classification is based on the stratigraphy and petrology of the deposits. The deposits of 
older ejecta are at the base of volcano, while the middle ejecta are deposited in mid-slope between 1,500 to $2,400 \mathrm{~m}$. The deposits of younger ejecta are found in the upper-slope from $2,400 \mathrm{~m}$ and above.

The older ejecta consist of olivine basalts containing 5 to 10 millimeter plagioclase (anorthite or bytownite) phenocrysts. Nearly aphyric or pyroxene phenocryst-bearing basaltic lava flows are also observed. The middle ejecta comprise basaltic lava sheets interbedded with thin layers of pyroclastic deposits. They are aphyric to porphyritic basalts with olivine or olivine and augite and/or hypersthene pyroxenes. The younger ejecta are basaltic lava flows and pyroclastic deposits.

\section{Tephrochronology}

Machida (1967) introduced a tephrochronological classification based on the distribution of tephra combined with Carbon-14 dating. The east-facing gentle marginal slopes of Fuji volcano have been intensively studied due to the suitable thickness and exposure of the lower horizons. His classification (table 1) is different from that of Tsuya (1940) and consists of three eruptive periods: 1) Older Fuji I (80,000 to 10,000BP); 2) Older Fuji II (10,000 to 8,000BP); and 3) Younger Fuji $(5,000 \mathrm{BP}$ to the present). Miyaji $(1988,1990)$ also used tephrochronology and ${ }^{14} \mathrm{C}$ dating, and based on more detailed description of the eruptive materials of Younger Fuji Volcano, subdivided the deposits into six periods: 1) 11,000 to $8,000 \mathrm{BP}$; 2) 8,000 to $4,500 \mathrm{BP}$; 3) 4,500 to 3,000 BP; 4) 3,000 to 2,000 BP; 5) 2,000 to $243 \mathrm{BP}$; and 6) 243BP (1707AD).

Older Fuji I is characterized by predominantly tephra producing eruptions, whereas Older Fuji II is characterized by lava flows (Machida, 1967). During 11,000 to 8,000 BP, the volcano erupted approximately $39.2 \mathrm{~km}^{3}$ of pahoehoe and aa from the summit and the northwestsoutheast aligned craters (Miyaji 1988,1990). Approximately $83 \%$ of the total $48 \mathrm{~km}^{3}$ of Younger Fuji eruptive products was erupted within this short period of 3,000 years. Fuji Volcano experienced quiescence between Old Fuji II and Younger Fuji, during which time Fuji black humic ash formed (Machida, 1967). Miyaji’s $(1988,1990)$ studies also confirmed the quiescent period since from $8,000 \mathrm{BP}$ to $4,500 \mathrm{BP}$ the volcano only erupted sporadically and produced only a relatively small amount of tephra and lava. Between 4,500 BP and 3,000 BP the volcano erupted approximately $0.3 \mathrm{~km}^{3}$ of basaltic tephra and $3.0 \mathrm{~km}^{3}$ of basaltic lava. A relatively large Plinian eruption took place during 3,000 BP to $2,000 \mathrm{BP}$, depositing approximately $2.6 \mathrm{~km}^{3}$ of 
tephra. During 2,000 BP to 234 BP, Strombolian and sub-Plinian style eruptions deposited pyroclastic falls $\left(0.6 \mathrm{~km}^{3}\right)$ and lava flows $\left(0.6 \mathrm{~km}^{3}\right)$. During the $1707 \mathrm{AD}$ eruption, the volcano produced primarily Plinian eruptions.

Table 1. Summary of Machida's (1967) classification of Fuji Volcano eruptive products (modified after Machida, 1967).

\begin{tabular}{|l|l|l|l|l|}
\hline Age & Stage & Division & Volcanic product & Development \\
\hline Holocene & Younger Fuji & $\begin{array}{l}\text { Younger Fuji } \\
\text { tephra }\end{array}$ & $\begin{array}{l}\text { Pyroclastic fall } \\
\text { Pyroclastic flow } \\
\text { Lava flow } \\
\text { (all moderate) }\end{array}$ & $\begin{array}{l}\text { Construction of the younger } \\
\text { stratovolcano }\end{array}$ \\
\hline & Quiescence & $\begin{array}{l}\text { Fuji black } \\
\text { humic soil }\end{array}$ & Pyroclastic flow (small) & $\begin{array}{l}\text { Slight erosion on the flank and } \\
\text { deposition at the foot }\end{array}$ \\
\cline { 4 - 6 } & Older Fuji II & $\begin{array}{l}\text { Lava flow (large) } \\
\text { Pyroclastic fall (small) } \\
\text { Pyroclastic flow (small) }\end{array}$ & $\begin{array}{l}\text { Construction of lava-rich } \\
\text { volcano }\end{array}$ \\
\cline { 2 - 5 } & Older Fuji I & $\begin{array}{l}\text { Older Fuji } \\
\text { tepra }\end{array}$ & $\begin{array}{l}\text { Pyroclastic fall (large) } \\
\text { Pyroclastic flow } \\
\text { (moderate) } \\
\text { Lava flow (moderate) }\end{array}$ & $\begin{array}{l}\text { Erosion and local dislocation } \\
\text { by faulting at the foot } \\
\text { Construction of Old Fuji, } \\
\text { relatively lava - poor } \\
\text { endogenous stratovolcano }\end{array}$ \\
\hline
\end{tabular}

The Fuji tephra classification (table 1) of Machida (1967) includes: 1) Older Fuji tephra; 2) the Fuji black humic ash; and 3) Younger Fuji tephra (Machida, 1967). The older Fuji tephra is weathered scoriaceous lapilli beds with a thickness of $100 \mathrm{~m}$. It was deposited by repeated pyroclastic falls and surface weathering over a long period of time. Since there is no evidence of significant erosion, such as unconformities or buried soil bands, the explosive activity must have been relatively continuous without any significant periods of quiescence. Carbon-14 ages between 25,000 and 10,000 BP confirm that those are the eruptive materials from Older Fuji I.

The Fuji black humic ash overlies the Older Fuji tephra. This layer contains a soil profile, which was formed by weathering during the quiescent period. The thickness of the soil layer gradually increases toward the top of the volcano, while the layer gradually changes to laminated ash beds with altitude, resembling tephra fall. Carbon-14 ages of approximately 10,000 to 5,500 BP indicate that it was formed between Older Fuji II and Younger Fuji. 
The Younger Fuji tephra is composed of dark brownish scoriaceous lapilli beds several meters thick. The top layer is the most recent deposit of the 1707AD eruption. The ash distribution pattern over the area is similar to that of Older Fuji tephra indicating long-term stable wind directions.

\section{Geochemistry}

Most of the eruptive materials (99\%; Togashi et al., 1991) from Fuji Volcano are basaltic, primarily medium-K series and high-Al basalt (Togashi and Yamazaki, 1990). The major element oxides including $\mathrm{SiO}_{2}, \mathrm{MgO}$, and $\mathrm{Al}_{2} \mathrm{O}_{3}$ fall within restricted ranges of $48-52 \mathrm{wt} \%$, 4-6.5 $\mathrm{wt} \%$, and 16-18 wt\% respectively (Arculus et al., 1991). The $\mathrm{Al}_{2} \mathrm{O}_{3}$ versus $\mathrm{SiO}_{2}$ diagram (fig. 4) illustrates the limited major element oxide compositions of Fuji Volcano. In addition, $\mathrm{Sr}$ and $\mathrm{Nd}$ isotopic compositions from Fuji Volcano fall within very limited ranges, from 0.70335-0.70355 and 0.51300-0.51305 respectively (Togashi, 1990). These values are typical of depleted island arc basalts (Togashi, 1990).

Eruptive materials from throughout the history of Fuji Volcano have been analyzed for whole rock major and trace elements (Togashi, 1990; Togashi and Yamazaki, 1990; Takahashi et al., 1991). Takahashi et al. (1991) subdivided the eruptive products from Older Fuji into four different periods (table 2): 1) >66,000BP; 2) 66,000-50,000BP; 3) 50,000-22,000BP; and 4) 22,000-10,000BP. Togashi (1990) subdivided the Older Fuji eruptive products into three different periods, slightly different from Takahashi et al. (1991): 1) 80,000-50,000BP; 2) 50,00020,000BP; and 3) 20,000-10,000BP.

Most of the eruptive materials from Older Fuji (80,000-20,000BP) display relatively higher $\mathrm{Al}_{2} \mathrm{O}_{3}$ (18-20 wt\%; Togashi, 1990; fig. 4) than the eruptive materials from Younger Fuji. Early $(>66,000 \mathrm{BP})$ and Late $(22,000-10,000 \mathrm{BP})$ Older Fuji eruptive products have similar FeO*/MgO ratios, while Middle (66,000-22,000BP) Older Fuji eruptive products display relatively lower $\mathrm{FeO}^{*} / \mathrm{MgO}$ ratios compared to the rest of the eruptive materials from Fuji Volcano (table 2). In general, Older Fuji eruptive products are depleted in incompatible elements including Rb, K, Ba, Y, Zr, and Ti (table 2; Togashi, 1990; Takahashi et al., 1991) compared to Younger Fuji eruptive products. 

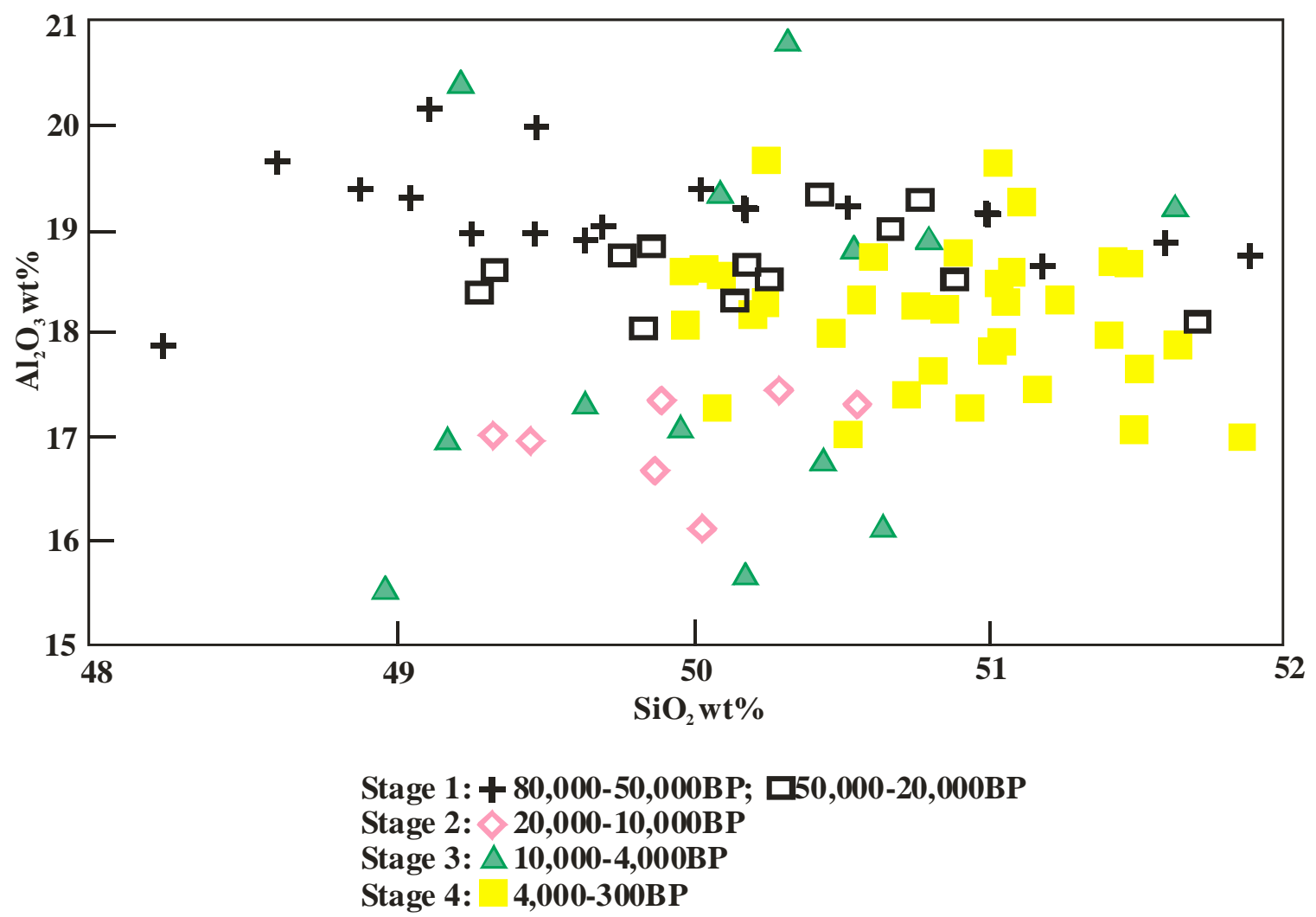

Fig. 4. $\mathrm{Al}_{2} \mathrm{O}_{3}$ versus $\mathrm{SiO}_{2}$ (modified after Togashi, 1990). The eruptive materials of Fuji Volcano display a limited range in major element concentrations.

Eruptive products from Younger Fuji have been subdivided into four different periods (Takahashi et al., 1991): 1) 10,000-8,000BP; 2) 8,000-3,000BP; 3) 3,000-2,000BP; and 4) $<2,000 \mathrm{BP}$. Eruptive materials from Younger Fuji show relatively constant $\mathrm{FeO} / \mathrm{MgO}$ ratios throughout (fig. 5; table 2), while other major and trace elements display slightly different trends during different eruptive periods. Overall, major and trace element variations from Younger Fuji can be divided into two compositional stages: 1) 10,000-8,000BP (Early) and $<2,000 \mathrm{BP}$ (Late); and 2) 8,000-3,000 and 3,000-2,000BP (Middle). The Early Younger Fuji eruptive products are distinct from Middle (8,000-2,000BP) Younger Fuji eruptive products, but show overall similarity to the Late Younger Fuji eruptive products with the exception of higher $\mathrm{TiO}_{2}$ and lower $\mathrm{Al}_{2} \mathrm{O}_{3}$ (table 2; fig. 5). 
Table 2. Whole rock chemistry of Fuji Volcano (modified after Takahashi et al., 1991). Ages in years before present (BP). Major element oxides in weight \%; trace element concentrations in ppm.

\begin{tabular}{|c|c|c|c|c|}
\hline & \multicolumn{4}{|l|}{ Older Fuji } \\
\hline Age (BP) & $>66,000$ & $\begin{array}{l}66,000- \\
50,000\end{array}$ & $\begin{array}{l}50,000- \\
22,000\end{array}$ & $\begin{array}{l}22,000- \\
10,000\end{array}$ \\
\hline$\overline{\mathrm{SiO}_{2}}$ & $52.0-54.7$ & $49.5-54.0$ & $49.7-53.5$ & $49.5-52.5$ \\
\hline $\mathrm{Al}_{2} \mathrm{O}_{3}$ & $19.0-19.9$ & 17.4-18.2 & $17.1-19.0$ & $15.8-19.0$ \\
\hline $\mathbf{K}_{2} \mathbf{O}$ & $0.43-0.56$ & $0.38-0.70$ & $0.32-0.67$ & $0.37-0.83$ \\
\hline $\mathrm{TiO}_{2}$ & $0.90-1.08$ & $1.00-1.33$ & $1.00-1.44$ & $1.08-1.69$ \\
\hline $\mathbf{P}_{2} \mathbf{O}_{5}$ & $0.12-0.17$ & $0.12-0.25$ & $0.10-0.21$ & $0.13-0.33$ \\
\hline $\mathbf{R b}$ & $4.85-6.67$ & $3.18-11.06$ & $4.39-8.33$ & $3.79-10.15$ \\
\hline Ba & $117-148$ & $110-186$ & $121-214$ & $128-221$ \\
\hline $\mathrm{Zr}$ & $45.8-61.6$ & $40.5-71.5$ & $45.8-82.6$ & $41.6-90.5$ \\
\hline $\mathbf{Y}$ & $17.3-18.4$ & $16.4-28.7$ & $17.9-26.4$ & $20.0-31.2$ \\
\hline \multirow[t]{2}{*}{$\mathbf{F e O} * / \mathbf{M g O}$} & $1.95-2.65$ & $1.45-2.08$ & $1.52-2.12$ & $1.72-2.68$ \\
\hline & \multicolumn{4}{|c|}{ Younger Fuji } \\
\hline Age (BP) & $\begin{array}{l}10,000- \\
8,000\end{array}$ & $\begin{array}{l}8,000- \\
3,000\end{array}$ & $\begin{array}{l}3,000- \\
2,000\end{array}$ & $<2,000$ \\
\hline $\mathrm{SiO}_{2}$ & $49.0-51.5$ & $49.2-51.7$ & $49.8-52.9$ & $50.6-52.7$ \\
\hline $\mathrm{Al}_{2} \mathbf{O}_{3}$ & $15.5-17.9$ & $18.9-21.5$ & $17.4-19.2$ & $16.0-18.4$ \\
\hline $\mathbf{K}_{2} \mathbf{O}$ & $0.60-0.90$ & $0.27-0.52$ & $0.48-0.69$ & $0.60-0.85$ \\
\hline $\mathrm{TiO}_{2}$ & $1.40-1.79$ & $1.04-1.33$ & $1.08-1.44$ & $1.23-1.63$ \\
\hline $\mathbf{P}_{2} \mathbf{O}_{5}$ & $0.25-0.36$ & $0.14-0.24$ & $0.18-0.27$ & $0.23-0.33$ \\
\hline $\mathbf{R b}$ & $8.26-17.24$ & $4.83-10.69$ & $8.28-12.31$ & $9.66-15.86$ \\
\hline Ba & $198-279$ & 113-179 & $165-202$ & $179-255$ \\
\hline $\mathrm{Zr}$ & $76.3-106.3$ & $47.4-55.6$ & $62.2-87.4$ & 69.6-106 \\
\hline $\mathbf{Y}$ & $26.3-33.6$ & $19.2-25.6$ & $20.9-27.6$ & $20.4-31.2$ \\
\hline FeO*/MgO & $1.83-2.91$ & $1.69-2.43$ & $1.56-2.80$ & $1.68-2.62$ \\
\hline
\end{tabular}


Major elements including $\mathrm{K}_{2} \mathrm{O}$, $\mathrm{TiO}_{2}$, and $\mathrm{P}_{2} \mathrm{O}_{5}$ are higher (fig. 5), while trace elements including $\mathrm{Rb}, \mathrm{Ba}, \mathrm{Y}$, and $\mathrm{Zr}$ are enriched (fig. 6) in Early and Late Younger compared to the Middle Younger Fuji eruptive products. Eruptive materials from the Middle Younger Fuji display higher $\mathrm{Al}_{2} \mathrm{O}_{3}$, lower $\mathrm{K}_{2} \mathrm{O}, \mathrm{TiO}_{2}$, and $\mathrm{P}_{2} \mathrm{O}_{3}$ (fig. 5), and are depleted in $\mathrm{Rb}, \mathrm{Ba}$, $\mathrm{Y}$, and $\mathrm{Ba}$ (fig. 6) compared to the Early and Late Younger Fuji eruptive materials (table 2; fig. 5); eruptive materials from 8,000-3,000BP in particular show distinct major and trace element variations.
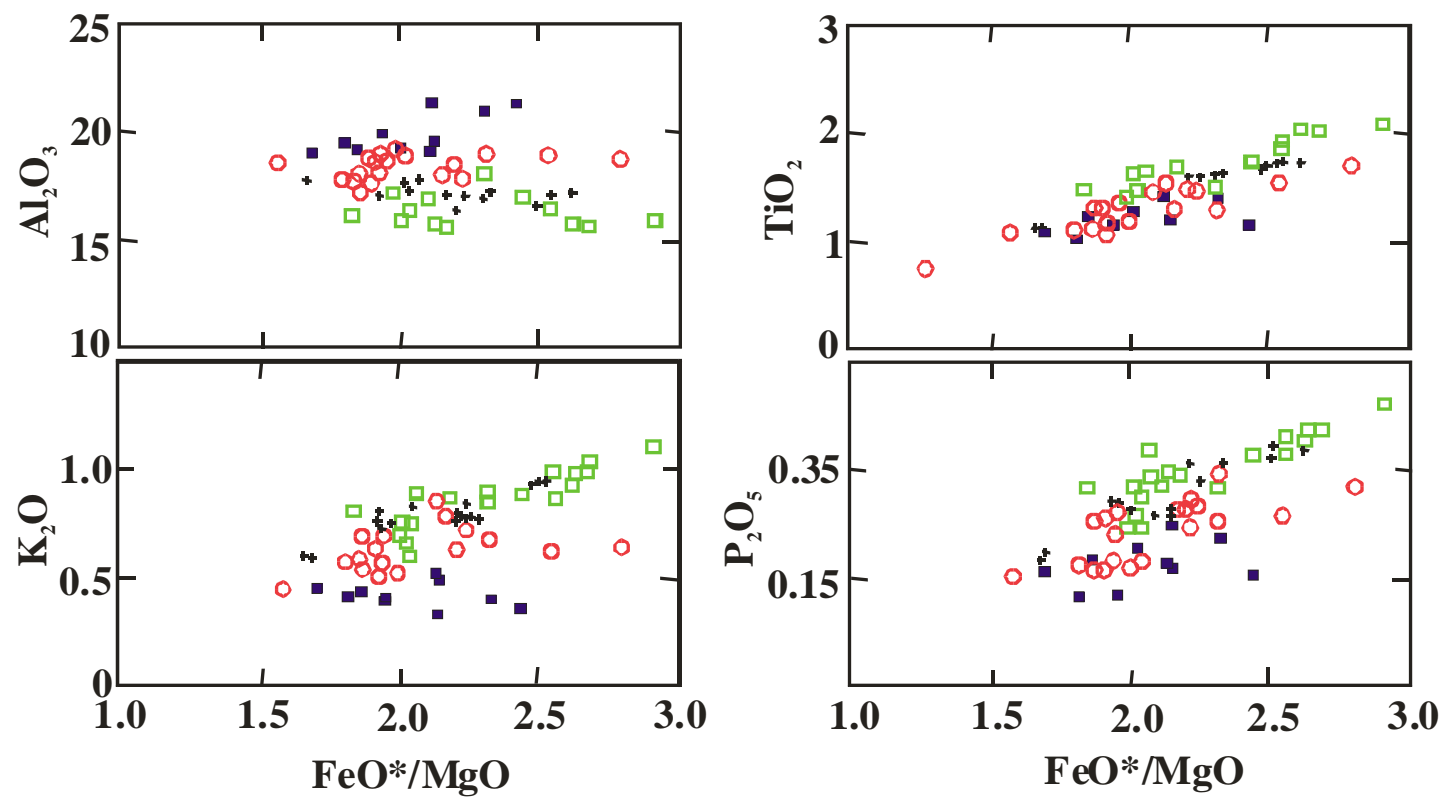

$$
\text { 8,000-10,000BP (๖); 3,000-8,000BP (.); 2,000-3,000BP (o); Present-2,000BP (*) }
$$

Fig. 5. Major element oxides versus $\mathrm{FeO} / \mathrm{MgO}$ for Younger Fuji samples (modified after Takahashi et al., 1991).

It is worth noting that the style of eruptive activities that took place during the Present2,000 BP stage are distinct from those of other stages, with eruptions mainly on the flanks of the volcano and varying crater elevations from 3,000 to $1,000 \mathrm{~m}$. $\mathrm{FeO} * / \mathrm{MgO}$ ratios (fig. 7) show an inverse correlation with crater elevation; however, incompatible elements (fig. 7) do not show such a correlation. 

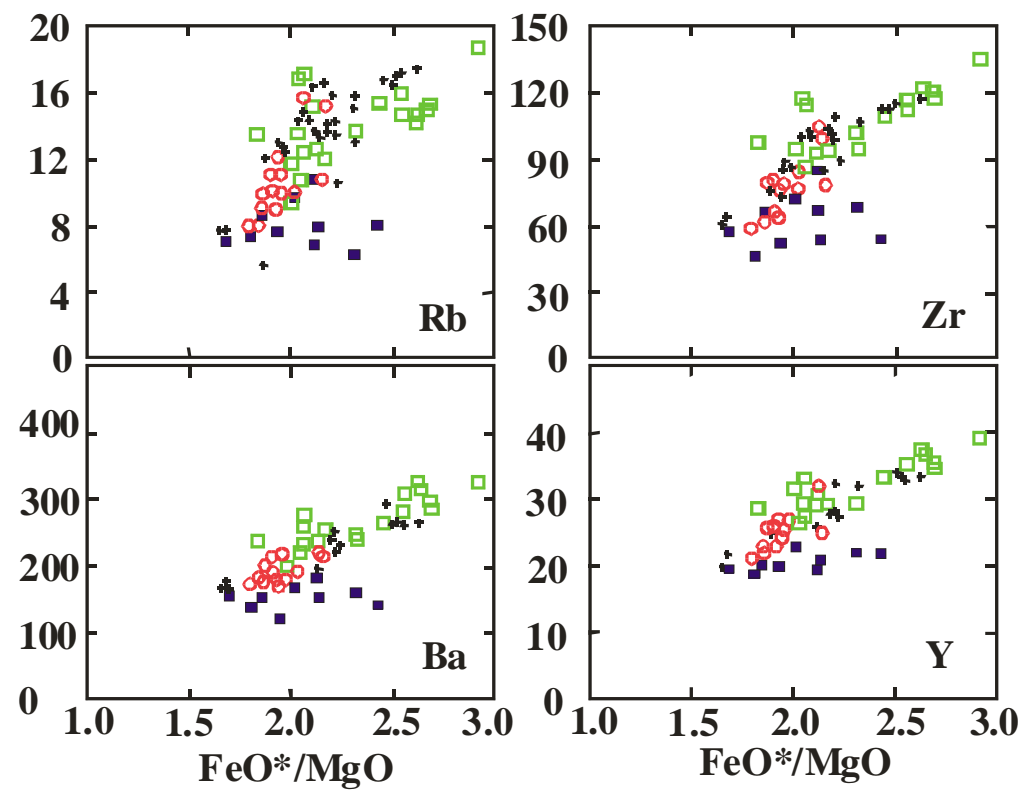

8,000-10,000BP (॰); 3,000-8,000BP (•); 2,000-3,000BP (o); Present-2,000BP ( *)

Fig. 6. Trace element concentrations versus $\mathrm{FeO} * \mathrm{MgO}$ for Younger Fuji samples (modified after Takahashi et al., 1991).

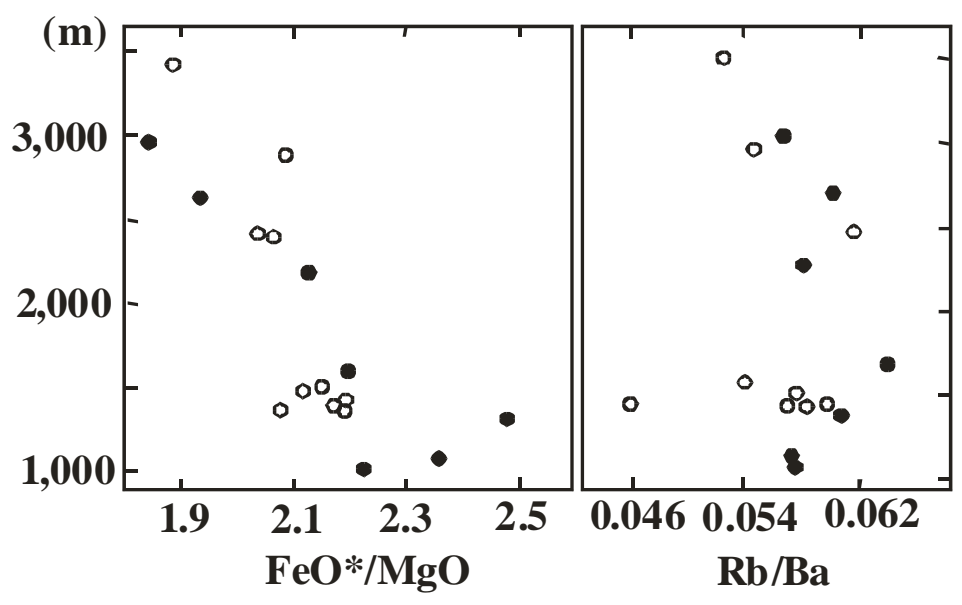

After 1,150BP (०); 2,000-1,150BP(•)

Fig. 7. The relationship between altitude of eruptive centers and whole rock chemistry (modified after Takahashi et al., 1991). 
Historic eruptions

The precise number of historic eruptions remains debatable; however, estimated numbers range from thirteen to eighteen based on geological evidence and written accounts. Thirteen eruptions documented in the geologic record include 781, 800, 826, 864, 870, 937, 999, 1033, 1083, 1511, 1560, 1700, and 1707 AD (Tsuya, 1955). Ten eruptions including 781, 800, 864, 937, 999, 1033, 1083, 1435, 1511, and 1707 AD have reliable written documentation, while six additional eruptions, including 826, 870, 952, 993, 1017, and $1427 \mathrm{AD}$, have less reliable written documentation (Koyama, 1998). Some older documents describing the eruptions before 780 AD have been found; however, there is no other conclusive evidence of those eruptions (Koyama, 1998). Despite the uncertainty in the precise number of eruptions, the fact that Fuji erupted frequently in historic times is clearly indicated.

Table 3. Summary of historical eruptions of Fuji Volcano (data compiled from Tsuya, 1955, 1968; Machida, 1981; Koyama, 1998). Black circle (•) indicates the presence of evidence.

\begin{tabular}{|c|c|c|c|c|}
\hline \multirow{2}{*}{$\begin{array}{l}\text { Year } \\
\text { (AD) }\end{array}$} & \multirow[t]{2}{*}{ Geological record } & \multicolumn{2}{|c|}{ Written documents } & \multirow[t]{2}{*}{ Remarks } \\
\hline & & Reliable & Less reliable & \\
\hline 781 & - & - & & Tephra eruption \\
\hline 800 & - & - & & Major eruption \\
\hline 826 & - & & - & Minor eruption \\
\hline 864 & - & - & & Major eruption \\
\hline 870 & - & & - & Minor eruption \\
\hline 937 & $\bullet$ & $\bullet$ & & Flank eruption \\
\hline 952 & & & - & \\
\hline 993 & & & - & \\
\hline 999 & $\bullet$ & $\bullet$ & & Flank eruption \\
\hline 1017 & & & - & \\
\hline 1033 & $\bullet$ & $\bullet$ & & Effusive eruption \\
\hline 1083 & $\bullet$ & $\bullet$ & & Minor eruption \\
\hline 1427 & & & - & \\
\hline 1435 & & - & & \\
\hline 1511 & $\bullet$ & $\bullet$ & & Minor eruption \\
\hline 1560 & - & & & Minor eruption \\
\hline 1700 & - & & & Minor eruption \\
\hline 1707 & - & - & & Major eruption \\
\hline
\end{tabular}


Written documents and geological studies agree that the 864AD and 1707AD eruptions were the most devastating eruptions in the history of Fuji Volcano. The 864AD eruption was a northwest flank eruption that occurred in June, which erupted a large quantity of augite and hypersthene phenocryst-bearing two-pyroxene-olivine-basalt (Tsuya, 1968; Machida, 1981). The lava flows were primarily blocky scoriaceous with some ropy and pahoehoe regions (Tsuya, 1968; Machida 1981). This eruption was unique with the formation of three volcanic lakes, Shoji-ko, Sai-ko, and Motosu-ko, and resulted in the largest number of written records next to the 1707 eruption (Koyama, 1998).

\section{The 1707 eruption}

The 1707 eruption is known as the Hoei Eruption among the Japanese, named after the era in which the eruption took place. It was one of the most explosive eruptions in the history of Fuji Volcano. Two major earthquakes preceded the eruption. The first earthquake, magnitude 8.2 (Aihara, 2003), occurred at Sagami Bay off the southern tip of the Boso Peninsula on December 31, 1703 (Tsuya, 1955). The second earthquake, magnitude 8.4 (Aihara, 2003), occurred in the sea off the southern tip of the Kii Peninsula on October 28, 1707 (Tsuya, 1955). The Weather Observatory (2001) summarized the detailed dates and times of volcanic phenomena that took place prior to and during the 1707 eruption (table 2). Around the beginning of December, Fuji Volcano experienced a series of seismic precursors. For the first several days, only small tremors were detected in the flank of the volcano. On December 15, much bigger tremors began, with a frequency of more than ten a day. From the evening of the $15^{\text {th }}$ to the early morning of the $16^{\text {th }}$, more than thirty tremors occurred on the southern flank and more than fifty tremors occurred on the northeastern flank, destroying some houses on the eastern flank.

Around 8 o'clock in the morning of the $16^{\text {th }}$, a black plume shot up into the sky (Miyaji, 1993). The main eruption that ejected pumice and ash followed two hours later. These eruptive materials melted the snow and caused avalanches. By the evening, the ejecta became more mafic and changed to scoria. The volcano became violent and emitted large numbers of volcanic bombs. Later studies showing that people left their belongings in their houses indicates that this eruption occurred suddenly and that people could not take their belongings out of the house in time (Miyaji, 1993). On the $17^{\text {th }}$, the eruption became less violent and eventually pulsed. A cryptic dome later named Hoei-san was formed about halfway up the southeast side of the 
volcano. This cryptodome consists of Older Fuji tephra; therefore, Older Fuji must have been pushed up to the surface by Hoei magma (Miyaji, 1993). On the $18^{\text {th }}$, a new crater was opened and started erupting. This phase of the eruption was sporadic and lasted until the end of the year. On the last day in 1707, the eruption once again became violent and ejected many volcanic bombs. The eruption ended with the end of the year.

Table 4. Description of the 1707 eruption (modified after the Weather Observatory, 2001).

\begin{tabular}{|l|l|l|l|}
\hline \multicolumn{1}{|c|}{ Date } & \multicolumn{1}{|c|}{$\begin{array}{c}\text { Time since the } \\
\text { initial eruption }\end{array}$} & \multicolumn{1}{|c|}{ Events } & \multicolumn{1}{|c|}{ Volcanic phenomena } \\
\hline Early Dec. & 10 days prior & Small tremors & Small tremors occurred \\
\hline 15-16 Dec. & 1 day prior & Tremors & Residents felt several tremors \\
\hline 16 Dec, AM & few hours prior & Strong tremors & Large-scale tremors occurred \\
\hline $\begin{array}{l}\text { 16 Dec, 10 AM- } \\
\text { 12PM }\end{array}$ & eruption & $\begin{array}{l}\text { Black plume } \\
\text { shoots up }\end{array}$ & Pumice eruption began at craters 2 and 3 \\
\hline 16 Dec, PM & few hours later & $\begin{array}{l}\text { Tephra falls in } \\
\text { Edo }\end{array}$ & Westward wind blew the ash to Edo \\
\hline 16 Dec. evening & half day later & $\begin{array}{l}\text { Frequent } \\
\text { lightning, tephra } \\
\text { changes to black }\end{array}$ & $\begin{array}{l}\text { Frequent volcanic lightning occurred } \\
\text { Ejecta changed from pumice to scoria }\end{array}$ \\
\hline 16 Dec. night & half day later & Houses burn & $\begin{array}{l}\text { Pumice fell on nearby village and burnt } \\
\text { houses }\end{array}$ \\
\hline 17 Dec. & 1 day later & $\begin{array}{l}\text { Tremors \& } \\
\text { lightning pulse }\end{array}$ & Eruption from craters 2 and 3 stops \\
\hline 17-18 Dec. & 1-2 days later & - & Hoei-san was formed \\
\hline 18-20 Dec. & 2-4 days later & $\begin{array}{l}\text { Tephra falls in } \\
\text { Edo }\end{array}$ & $\begin{array}{l}\text { Sporadic eruption from crater 1 began } \\
\text { (some were large-scale) }\end{array}$ \\
\hline 21-27 Dec. & 5-11 days later & $\begin{array}{l}\text { Tephra falls } \\
\text { decrease in Edo }\end{array}$ & Eruption scale became smaller \\
\hline 27-31 Dec. & 11-15 days later & Volcanic bombs & Volcanic bombs were erupted \\
\hline 1 Jan. 1708 & 16 days later & Eruption ends & Eruption ended \\
\hline
\end{tabular}

Three craters were formed in this series of eruptions (fig. 8). They are aligned and called the first, second and third crater from the highest to lowest elevation: 2300-3100, 2300-2500, and 2100-2300 m, respectively (Miyaji, 1993). The first crater is the biggest with a length of 1500 meters and a width of 750 meters. Since the second and third craters are eroded by the first crater, the eruption of the $16^{\text {th }}$ and $17^{\text {th }}$ took place in the second and third craters. The eruption on the $18^{\text {th }}$ and all subsequent eruptions took place in the first crater (Miyaji, 1993). 


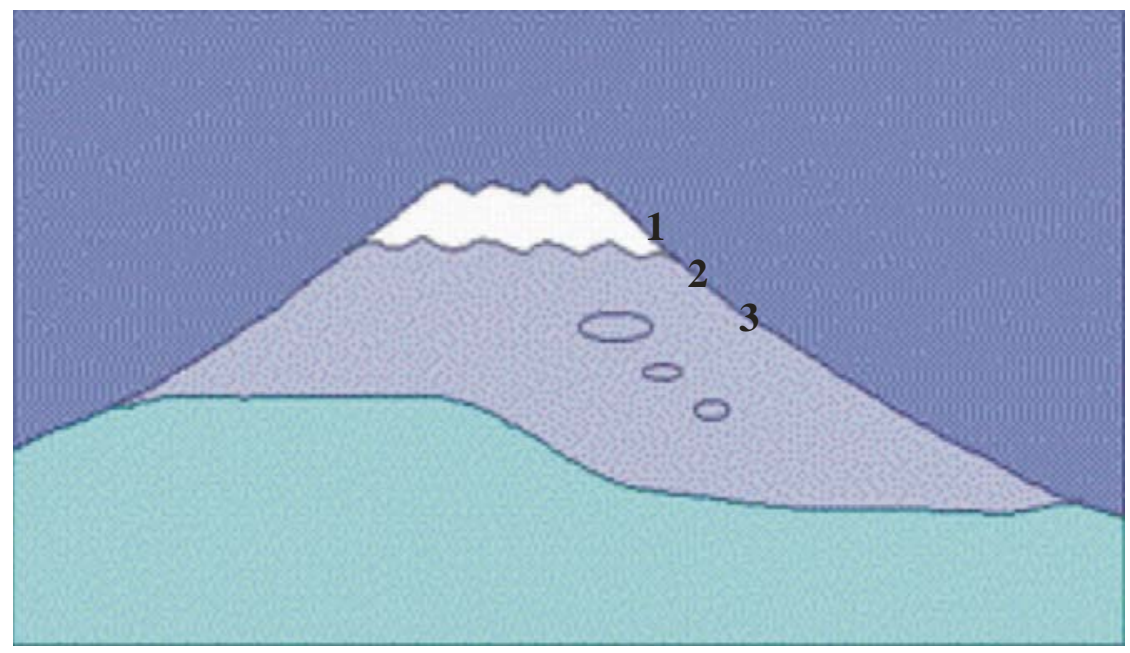

Fig. 8. Cartoon diagram of three craters of the 1707 eruption (modified after Aihara, 2003). These craters are aligned and called the first, second, and third crater from the highest to lowest elevation.

Stratigraphy of the 1707AD deposit

Miyaji (1984, 1993) subdivided the 1707 deposit into four fall units, Ho-I, -II, -III, and IV from the bottom to the top, based on grain size and constituents (fig. 9). The deposit is sandwiched in between soil layers, indicative of a continuous single eruptive event. No evidence of erosion is observed within the deposit.

The Ho-I unit is further subdivided into two fall units, Ho-Ia, and Ib. The Ho-Ia unit consists of mainly gray-white, porous, and coarse grained pumice, whereas the Ho-Ib unit is constituted of gray, porous, fine grained pumice, unique black-and-white banded pumice, red scoria and rock fragments. Ho-II is composed of black-gray, less porous and coarse-grained scoria, fine-grained red scoria, and rock fragments. Ho-III comprises mainly gray-black, porous, and coarse-grained scoria, red scoria, and rock fragments. Ho-IV consists of both coarse and fine-grained black scoria and rock fragments. Red scoria is not present in this fall unit.

Miyaji (1993) compiled historical documents and the distribution of tephra in order to determine the precise time of deposition of each fall unit. In Edo, the present-day Tokyo, a pumice ash-fall started around 1:00PM and changed to scoria by the evening. Therefore, silicic 
Ho-I materials were deposited over 4 to 6 hours. The distribution of the Ho-II unit indicates that materials were erupted from the second and third craters, suggesting that eruptions on the $16^{\text {th }}$ and $17^{\text {th }}$ formed the Ho-II unit. The thickness of the Ho-III unit indicates that it was formed around the $18^{\text {th }}$ to $20^{\text {th }}$ when the eruption was still active. Ho-IV was formed in the last stage of sporadic small-scale eruptions during the $21^{\text {st }}$ to $31^{\text {st }}$.

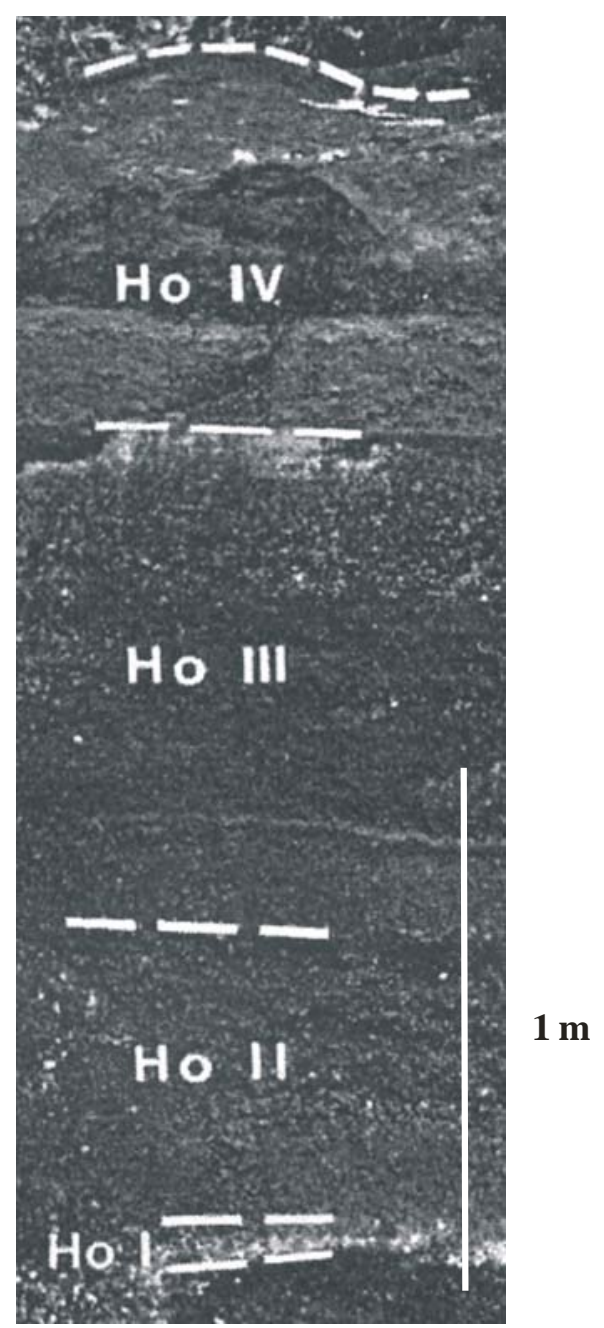

Fig. 9. Stratigraphy of the Fuji 1707 deposit (modified after Miyaji, 1984). The deposit has been subdivided into four fall units based on grain size and constituents (Miyaji,1984). 
The distribution of tephra

Based on Miyaji's (1993) research, the Weather Observatory (2001) constructed a table summarizing the eruptive volume, approximate date, approximate time and rate of eruption for each unit (table 3 ). The rate of eruption decreased rapidly with time. Within the first five days, Fuji Volcano produced more than half of the total erupted tephra (Weather Observatory, 2001). Most of the tephra were deposited in a fan-shaped lobe, eastward from the craters (Tsuya, 1968; Machida, 1981).

Table 5. Summary of the Fuji 1707 tephra eruption (modified after the Weather Observatory, 2001).

\begin{tabular}{|l|l|l|l|l|}
\hline Fall unit & Amount $\left.\mathbf{( k m}^{\mathbf{3}}\right)$ & App*. Date & App*. Time (h) & Rate $\left.\mathbf{( 1 0}^{-3} \mathbf{k m}^{\mathbf{3}} / \mathbf{h}\right)$ \\
\hline $\begin{array}{c}\text { Ho-I } \\
\text { Ia } \\
\text { Ib }\end{array}$ & $\begin{array}{c}0.048 \\
(0.032) \\
(0.016)\end{array}$ & $\begin{array}{l}16 \text { Dec. 2001, } \\
10: 00-16: 00\end{array}$ & 6 & 8.00 \\
\hline Ho-II & 0.120 & $\begin{array}{l}\text { 16 Dec. 2001,16:00-17 } \\
\text { Dec. 2001, 24:00 }\end{array}$ & 32 & 3.75 \\
\hline Ho-III & 0.176 & $\begin{array}{l}\text { 18 Dec. 2001, 00:00- } \\
\text { 20 Dec. 2001, 24:00 }\end{array}$ & 72 & 2.44 \\
\hline Ho-IV & 0.332 & $\begin{array}{l}\text { 21 Dec. 2001, 00:00-27 } \\
\text { Dec. 2001, 24:00 }\end{array}$ & 192 & 1.73 \\
\hline Total & $\mathbf{0 . 6 7 6}$ & $\begin{array}{l}\text { 16 Dec. 2001,10:00- } \\
\text { 27 Dec. 2001, 24:00 }\end{array}$ & $\mathbf{3 0 2}$ & $\mathbf{2 . 2 4}$ \\
\hline
\end{tabular}

*Approximate

Major and trace element variations

Nakamura et al. (1986) divided the 1707 deposit into 17 fall units based on visual differences (fig. 10) and analyzed whole rock major and trace element concentrations (table 6 and 7). Their samples were collected from Midono, Shizuoka, $14 \mathrm{~km}$ east of the craters at an outcrop that no longer exists. The thickness of the deposit is 270 centimeters. In comparison with Miyaji's fall units, the fall units 1, 2-5, 6-14, and 15-17 correspond to Ho-I, Ho-II, Ho-III, and Ho-IV respectively.

The fall units 1 and 2 clearly show a change in $\mathrm{SiO}_{2}$, from dacite to andesite (fig. 11). The other oxide concentrations also show a shift from felsic to intermediate with an increase in $\mathrm{Fe}_{2} \mathrm{O}_{3}, \mathrm{CaO}, \mathrm{MgO}, \mathrm{MnO}, \mathrm{P}_{2} \mathrm{O}_{5}$, and $\mathrm{TiO}_{2}$ and a decrease in $\mathrm{Na}_{2} \mathrm{O}$ and $\mathrm{K}_{2} \mathrm{O}$. From fall unit 5 to 6, there was also a rapid change in chemistry, shifting to more mafic in composition. Although the 
rapid change from 1 to 2 is visible in hand samples, the rapid change from 5 to 6 is only observable with whole rock chemistry. However, despite the visible differences in grain size and color in fall units 6 to 17, they are similar in whole rock chemistry.

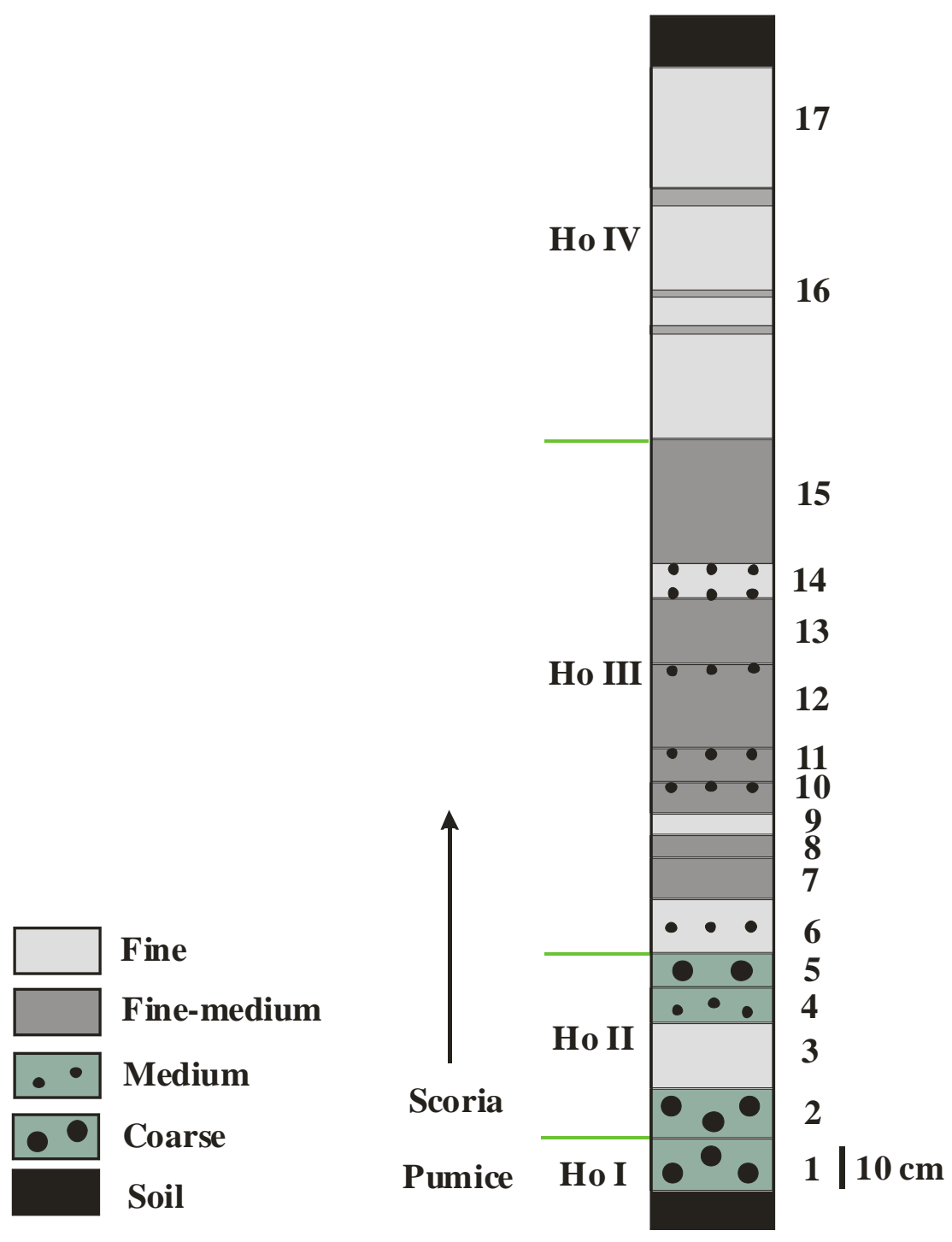

Fig. 10. Stratigraphy of the Fuji 1707 deposit (modified after Nakamura et al., 1986). The deposit has been subdivided into 17 fall units by Nakamura et al. (1986). The correlation between Miyaji's (1984) classification is shown on the left. 
The trace element data show some unexpected trends (fig. 12) given the major element variations. $\mathrm{Sr}, \mathrm{Pb}$, and $\mathrm{Zn}$ stay relatively constant throughout the fall units, whereas $\mathrm{Li}$ and $\mathrm{Rb}$ decrease by a factor of 2 from bottom to top. $\mathrm{Co}, \mathrm{Ni}$ and $\mathrm{Cu}$ increase by a factor of 2 to 5 from bottom to top. Considering the significant change in $\mathrm{SiO}_{2}$ from 64 (wt\%) to 49 (wt\%), it is surprising that no variations in $\mathrm{Sr}, \mathrm{Pb}$, and $\mathrm{Zn}$ are observed.

\section{Summary}

Fuji Volcano has been active throughout its history, and has produced a large volume of primarily basaltic deposits. Although several different detailed classification schemes have been developed for the stratigraphy of the Fuji deposits, three major eruptive cycles are widely recognized. These eruptive cycles are associated with three stratovolcanoes including the present-day Fuji Volcano (Younger Fuji) and its predecessors Older Fuji and Komitake.

Two eruptions in Fuji's recent history (past 3,000 years) were characterized by unusually silicic magmas, including andesite and dacite. The more recent of these two eruptions (1707AD), is the most recent eruption of Fuji Volcano. The stratigraphy of the resulting deposit has been

thoroughly studied, and, combined with historic accounts, detailed reconstructions of this unusually explosive Fuji eruption have been developed. However, only preliminary petrographic and geochemical data are available for this deposit, and the processes responsible for formation of the evolved magmas are thus not well constrained. The purpose of the current study, the results of which are discussed in Chapter 3, is to develop a better understanding of the processes that resulted in the formation of the silicic magmas erupted in the explosive 1707AD eruption of Fuji Volcano. 


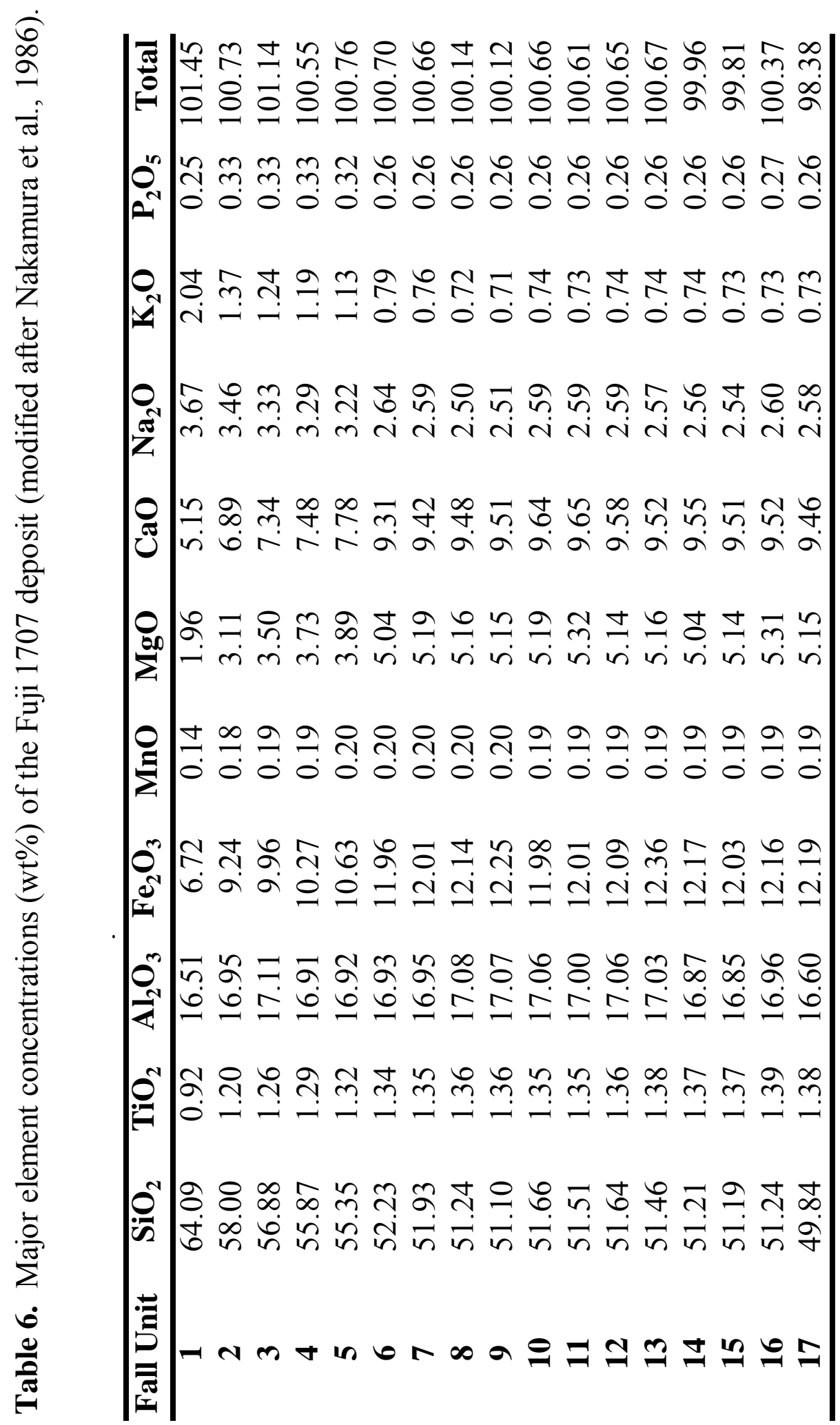




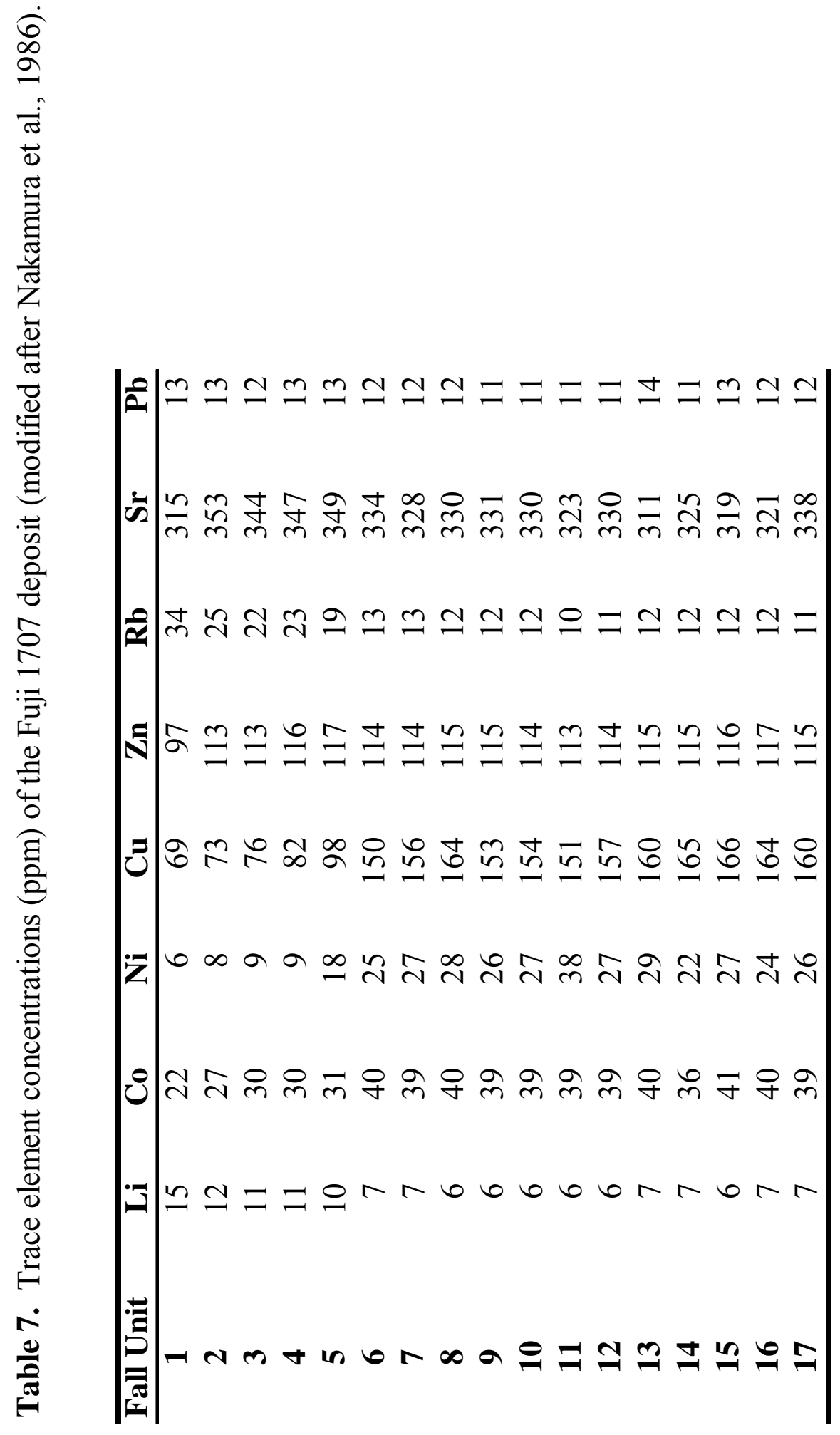




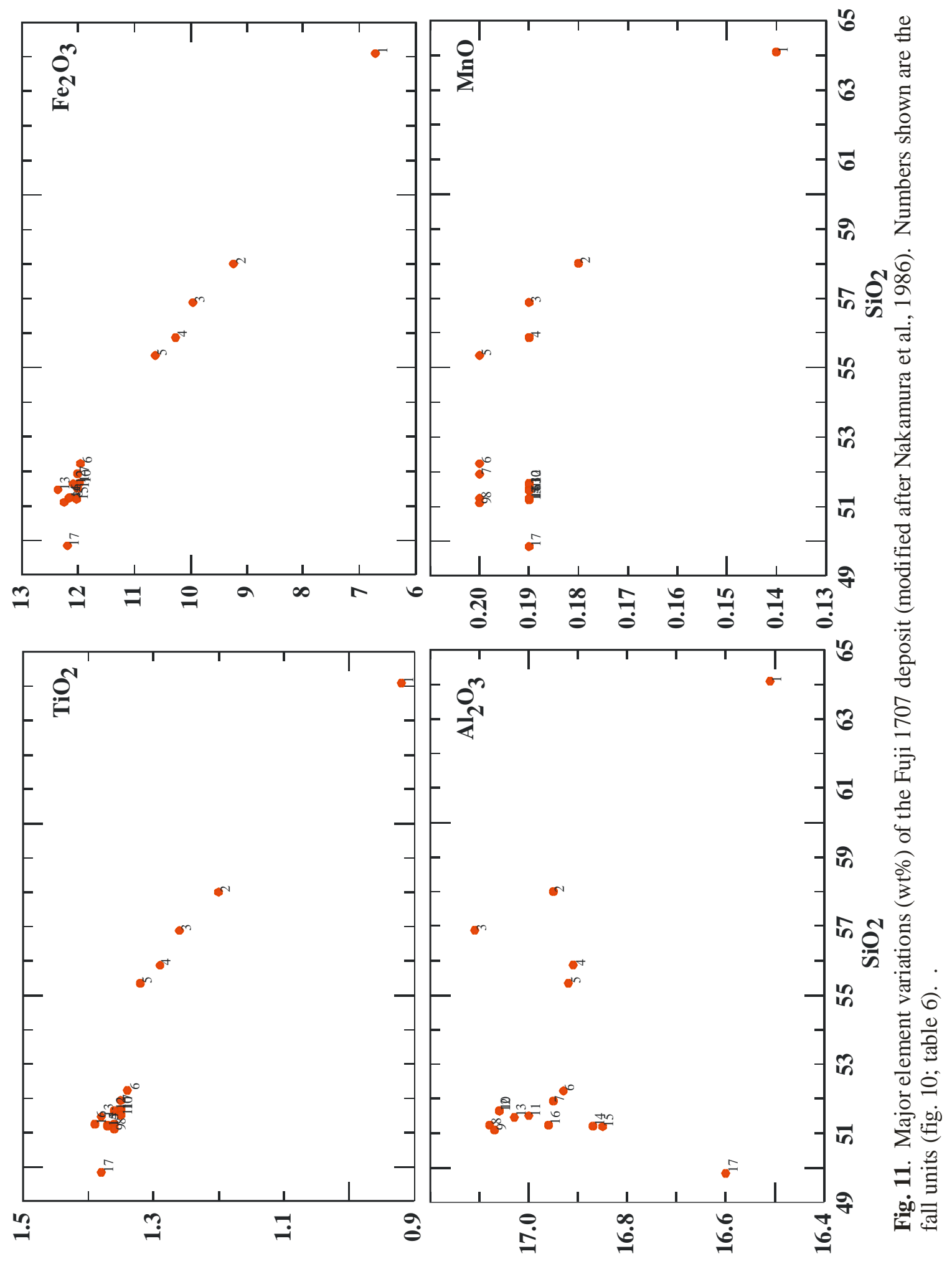



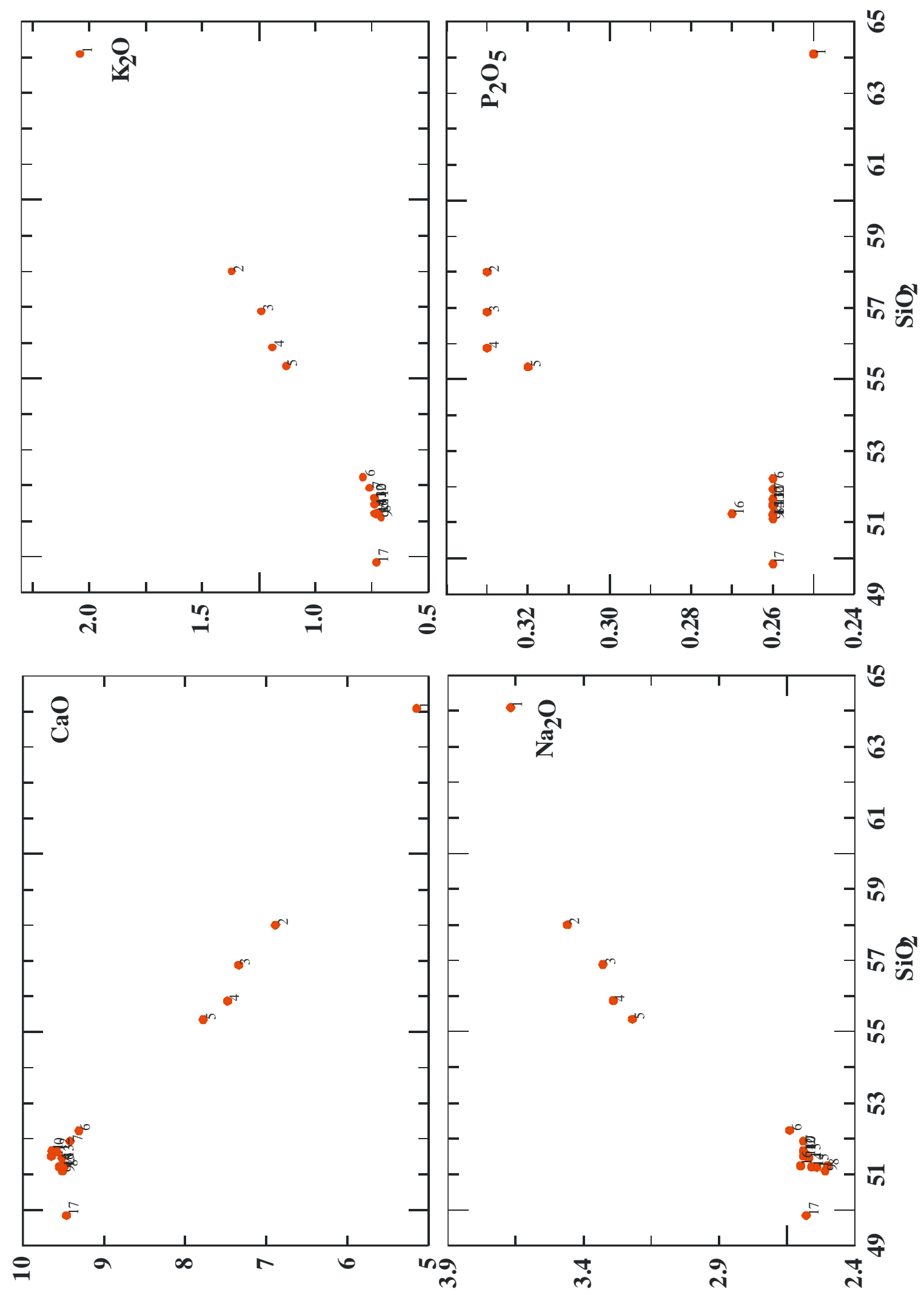


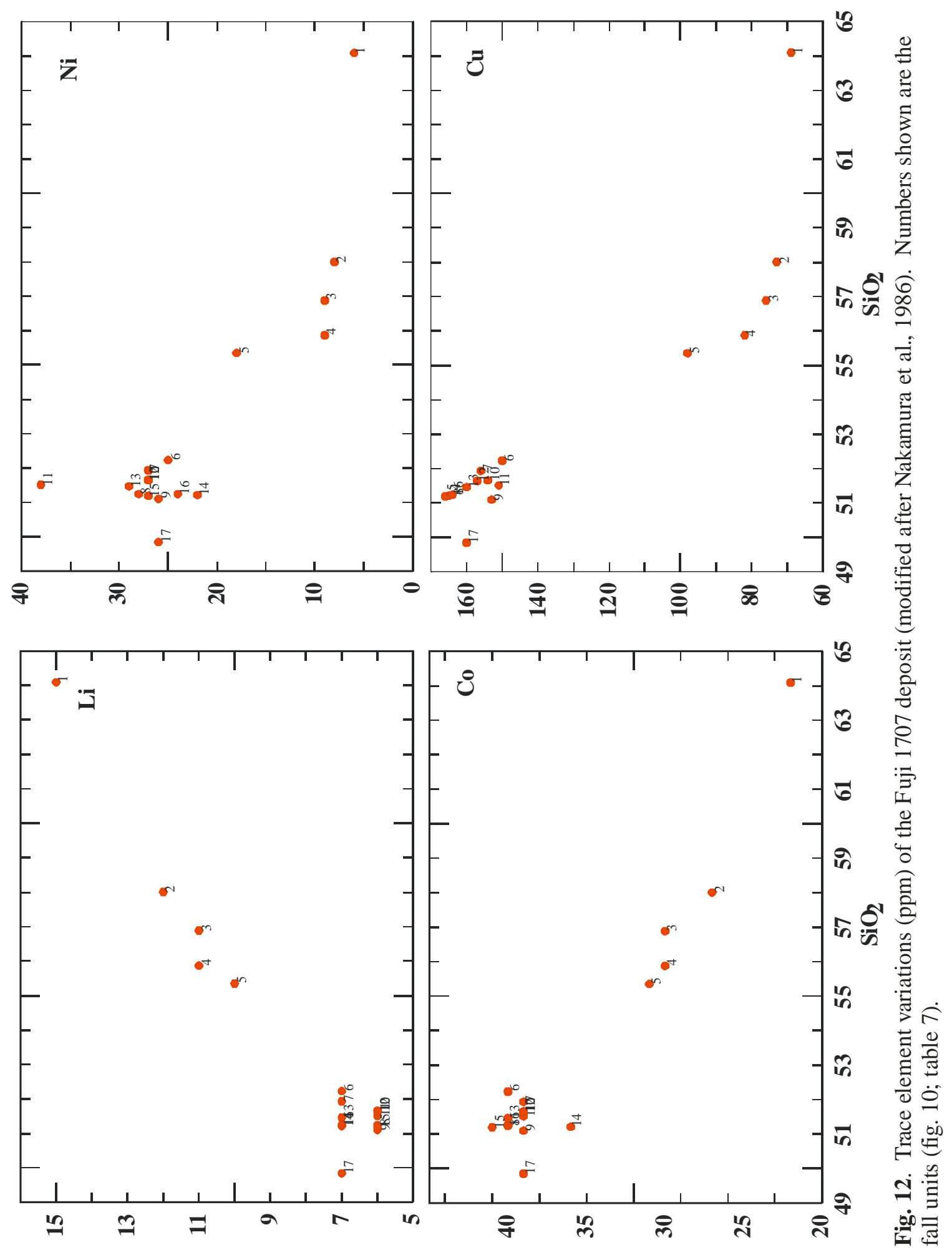



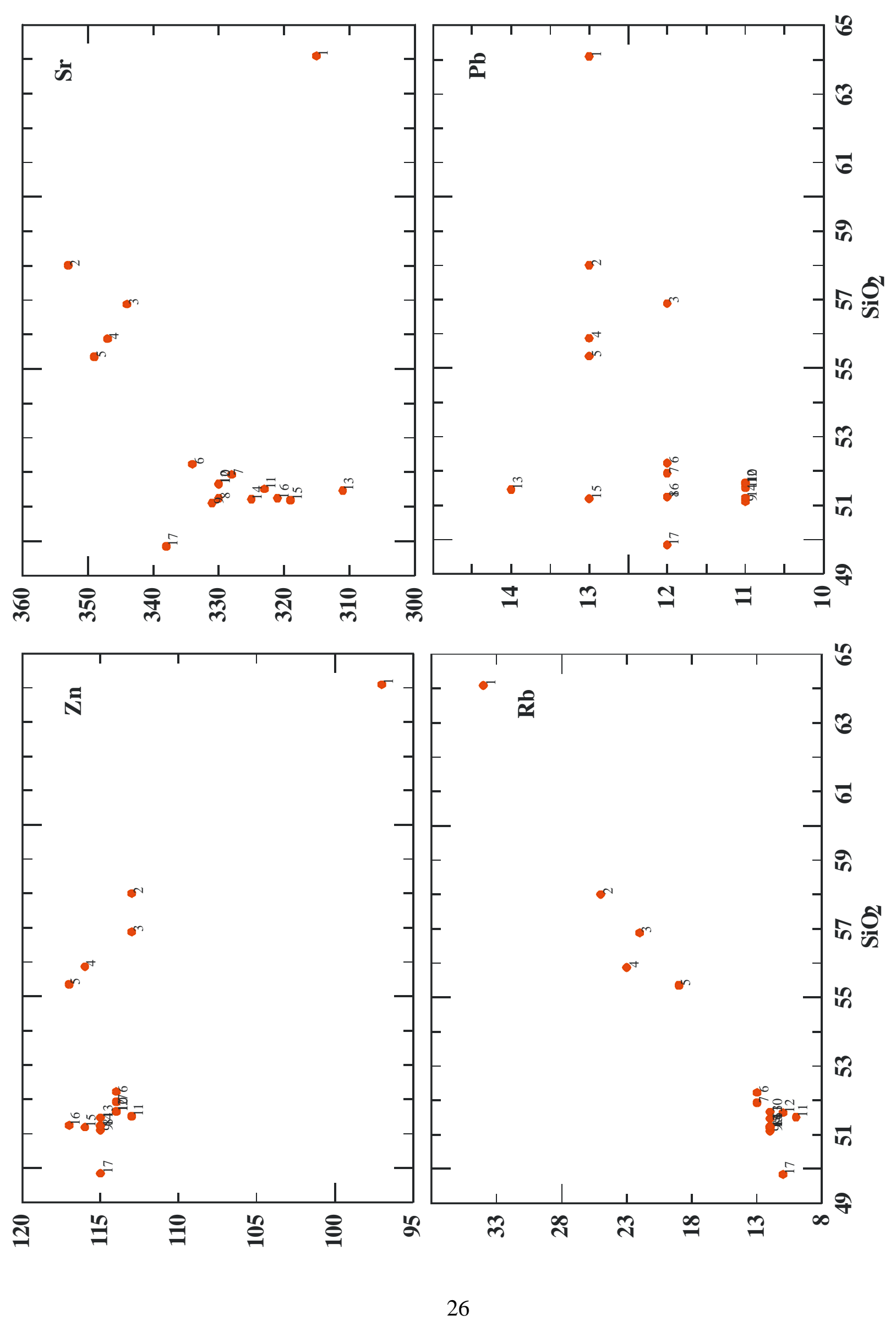


\section{Chapter 2}

\section{Introduction to chemically zoned magma chambers}

\section{Introduction}

Most deposits from large, explosive volcanic eruptions are chemically zoned, representing chemical gradients in the magma chamber feeding the volcano. As magma evolves, it becomes more silicic and volatile-rich towards the top of the chamber, becoming potentially explosive. Chemically zoned volcanic deposits typically display a decrease in $\mathrm{SiO}_{2}$ and increase in phenocryst contents from the bottom to the top. The processes generating such complex chambers are still being debated due to the complexity of interrelated variables and the wide ranges in volumes, compositions, and life spans of magmatic systems (Wörner and Schmincke, 1984). Based on previous studies, commonly proposed petrogenetic processes include crystal fractionation, magma mixing/replenishment, and crustal assimilation.

Closed system magma chamber evolution

Closed system crystal fractionation is recognized as one of the important processes that gradually forms chemical gradients within magma chambers (Michael, 1983). With a drop of magma temperature, crystals are formed and removed, changing the chemical composition of the residual liquid. Several parameters including starting bulk composition, temperature, and pressure control the process. Fractional crystallization can explain the systematic change in major and trace element concentrations in many chemically zoned eruptions (Wörner and Schmincke, 1984).

Expected geochemical features of magmas that have experienced closed system fractional crystallization include: 1) kinks in trends on element-element diagrams; 2) enrichment in rare earth elements (REE) and other incompatible trace elements with increasing $\mathrm{SiO}_{2}$; and 3) constant isotopic compositions. Due to the fact that fractionating minerals typically change with time as a magma evolves, element-element diagrams display kinks in the trends. REEs show relative enrichment from least evolved to most evolved rocks due to their incompatibility in the major mineral phases. Isotopic compositions stay constant throughout the closed system crystal fractionation process unless magma residence times are sufficiently long that radioactive decay 
modifies the isotopic compositions.

Open system magma chamber evolution

Potential open system magma chamber processes include magma mixing/replenishment (Wörner and Wright, 1984), crustal assimilation (Duffield et al., 1995), and volatile transfer (Bailey, 1970), processes invoked to explain isotopic heterogeneity in the magma chambers. Isotopic signatures can provide important information regarding the sources and petrogenesis of magmas. Due to the fact that magmas experience disequilibrium conditions during open system processes, petrographic features such as reverse zoning, resorbed and sieved textures, and disequilibrium mineral assemblages may also record the open system processes. Simple binary mixing results in linear trends between two end members on element-element diagrams.

Due to their high temperatures, magmas can melt and incorporate country rock. Since crust usually has radiogenic isotopic signatures, magmas that have assimilated crust can display radiogenic isotopic signatures compared to uncontaminated magma. In some cases, crustal assimilation cannot be detected by common isotope systems such as $\mathrm{Sr}, \mathrm{Nd}$, and $\mathrm{Pb}$, used to evaluate igneous processes. Since there is sometimes not a large difference in isotopic compositions between the magma and the potential contaminants (crust or sediment) in those isotope systems, trace amounts of assimilation can be accommodated with no change in $\mathrm{Sr}, \mathrm{Nd}$, or $\mathrm{Pb}$ isotope signatures. In such cases, Os isotopes can serve as a very sensitive tracer for crustal assimilation, due to the extreme difference in ${ }^{187} \mathrm{Os} /{ }^{188} \mathrm{Os}$ ratios between the mantle and crust.

\section{Case Studies}

Several well-studied chemically zoned volcanic deposits, including the Bishop Tuff in eastern California, the Laacher See in Eifel Germany, and the Bandelier Tuff in the Jemez Volcanic Field, New Mexico, provide insight into processes operating in the evolution of large silicic magmatic systems. Although the precise petrogenetic processes operating in these magmatic systems have long been debated, comprehensive evaluation of petrography, major and trace element concentrations, REE abundances, and isotopic compositions have led to some constraints on the petrogenetic processes. 


\section{Bishop Tuff}

The Bishop Tuff, a high-silica rhyolitic ash flow tuff is probably the most thoroughly studied chemically zoned volcanic deposit in the world. It was deposited by a catastrophic eruption at 740,000 BC, from Glass Mountain in eastern California.

The Bishop Tuff is a typical zoned deposit, representing the inverse of chemical gradients in the magma chamber. Concentrations of $\mathrm{Sr}, \mathrm{Ba}, \mathrm{Eu}, \mathrm{Mg}, \mathrm{Fe}$ and light REE increase while $\mathrm{Nb}$, $\mathrm{Cs}, \mathrm{Rb}, \mathrm{Sb}, \mathrm{Sn}, \mathrm{W}$, and heavy REE decrease from the bottom to the top of the deposit (Michael, 1983). Mineral phases observed are Ti-Fe oxide, quartz, sanidine, oligioclase, biotite, ilmenite, titanomagnetite, zircon, apatite, and allanite (Hildreth, 1979).

Hildreth (1979) originally proposed that thermogravitational diffusion, a liquid-state fractionation process, generated the highly fractionated Bishop Tuff because it was difficult to explain the trace element variations. However, later studies (Michael, 1983; Cameron, 1984; Knesel and Davidson, 1997) revealed that crystal fractionation can in fact explain the observed elemental concentrations when fractionation of trace mineral phases was accounted for. Fractional crystallization has become the widely accepted process to explain the generation of the chemically zoned Bishop Tuff.

However, the explanation for the isotopic heterogeneity in the Bishop Tuff is still being debated in terms of in-situ radioactive decay versus crustal assimilation. Christensen and Halliday (1996) proposed that the rhyolitic magma experienced rapid differentiation in a longlived magma chamber based on apparent $\mathrm{Rb}-\mathrm{Sr}$ isochrons and $\mathrm{Nd}$ isotopic compositions of melt inclusions. However, Duffield et al. (1995) argued that contamination by roof-rocks at the top of the magma chamber was responsible for the chemical as well as isotopic gradients in the Bishop Tuff. A recent study by Ried and Coath (2000) found evidence against a long-lived (>100 ka) magma chamber based on $\mathrm{U}-\mathrm{Pb}$ ages of zircons, providing additional constraints on the role of open system processes in the Bishop Tuff.

Laacher See

The Laacher See Volcano is located in the East Eifel, West Germany. An eruption in 11,000 BC resulted in a zoned deposit ranging from highly evolved phonolite to mafic phonolite. Three tepra units are recognized including the LLST, MLST, and ULST (Lower, Middle, Upper Laacher See Tephra; Wörner and Schmincke, 1984). Major and trace element concentrations 
measured by Wörner and Schmincke (1984) and Wörner et al. (1983) show variations throughout the deposit, displaying systematic correlations with stratigraphic position. LLST are alkali-rich and enriched in incompatible trace elements. Sr concentrations decrease and Nd concentrations increase rapidly toward the top of LLST. The boundary between LLST and MLST shows relatively steeper chemical gradients, shifting from differentiated phonolite (LLST) to mafic phonolite (MLST). Major and trace element concentrations of MLST are intermediate between LLST and ULST. ULST show the highest $\mathrm{MgO}$ and $\mathrm{Sr}$ and lowest $\mathrm{Na}_{2} \mathrm{O}, \mathrm{Cl}$, $\mathrm{Nd}$ and $\mathrm{Th}$ concentrations. The phenocryst phases observed were feldspars, hauyne, amphibole, clinopyroxene, sphene, apatite, mica, olivine, nepheline, zircon, and cancrinite (Wörner and Schmincke, 1984). The chemical variations can be explained by crystal fractionation of the observed mineral phases.

The role of open system processes is evidenced by $\mathrm{Sr}$ and $\mathrm{Nd}$ isotopic compositions (Wörner et al., 1985). Sr isotopes show significant variations with ${ }^{87} \mathrm{Sr} /{ }^{86} \mathrm{Sr}$ ranging from 0.70477-0.70486 (ULST) to 0.71122 (LLST), while $\mathrm{Nd}$ isotopes display a relatively narrow range in ${ }^{143} \mathrm{Nd} /{ }^{143} \mathrm{Nd}$, from 0.51261 (ULST) to 0.51268 (LLST). These isotopic gradients are attributed to variable degrees of assimilation of crustal materials including Devonian sedimentary rocks or metamorphic basement (Wörner et al., 1985). Abundant inclusions of midcrustal rocks are found in East Eifel basanite scoria cones, providing additional evidence for crustal assimilation.

In order to explain petrographic observations and chemical and isotopic signatures of the final pyroclastic products erupted from Laacher See Volcano, Wörner and Wright (1984) proposed that magma mixing played an important role. Disequilibrium textures such as resorption of phonolitic phenocrysts as well as reverse zoning were observed. Linear relationships between two end members on element-element diagrams as well as variations in $\mathrm{Sr}$ isotopic compositions could be attributed to magma mixing. However, Wörner et al. (1985) argued that the above observations are better explained by crustal assimilation, because the $\mathrm{Sr}$ isotopic signatures are very radiogenic, indicative of crustal assimilation. Summarizing all studies, Wörner et al. (1985) proposed that the chemically zoned magma chamber underneath the Laacher See Volcano evolved through crystal fractionation with variable degrees of crustal assimilation. 


\section{Bandelier Tuff}

The Bandelier Tuff is a zoned deposit from Valles Caldera, in the Jemez Volcanic Field, New Mexico. The Bandelier Tuff consists of two rhyolitic ignimbrite members: the Otowi Member (lower) and Tshirege Member (upper). The Otowi Member and Tshirege Member were erupted at 1.45 Ma and 1.12 Ma respectively. The Otowi Member and Tshirege Member both consist of ignimbrite underlain by pumice fall (Wolff et al., 1999).

Major element concentrations in the Otowi Member display very little variation throughout the deposit, while trace element concentrations show significant variations; incompatible trace elements show three- to five-fold variations (Kuentz, 1986; Spell et al., 1990; Wolff et al., 1999). Incompatible elements display linear correlations between early and late erupted pumice clasts in most element-element diagrams (Wolff et al., 1999). Elemental variations can be explained by crystal fractionation of the observed phenocryst assemblage including sanidine + quartz + clinopyroxene + magnetite + zircon + allanite \pm fayalite \pm chevkinite \pm britholite (Wolff and Ramos, 2003).

The role of open system processes has been vigorously debated for years. In order to evaluate the cause of isotopic heterogeneity as well as residence time of the magma chamber, $\mathrm{Sr}$ isotopes (Wolff et al., 1999), and Pb isotopes (Wolff and Ramos, 2003) were utilized.

Although both in-situ radioactive decay and assimilation can modify the Sr isotopic compositions of magma, these processes display different trends as illustrated in the ${ }^{87} \mathrm{Sr} /{ }^{86} \mathrm{Sr}$ versus ${ }^{87} \mathrm{Rb} /{ }^{86} \mathrm{Sr}$ diagram (fig. 1; Wolff et al., 1999). Sr isotope compositions of feldspars, glasses, and quartz phenocrysts with glass inclusions are consistent with contamination by Proterozoic basement with higher Sr contents and radiogenic Sr isotopic compositions (Wolff et al., 1999). Quartz with glass inclusions display more radiogenic Sr signatures compared to other phases. These quartz grains were interpreted to have formed at the edge of the magma chamber, and incorporated melts of the amphibolite country rock (Wolff et al., 1999).

$\mathrm{Pb}$ isotope variations provide additional insights into the ongoing debate on in-situ radioactive decay versus assimilation to explain the isotopic heterogeneity. A positive correlation between ${ }^{87} \mathrm{Sr} /{ }^{86} \mathrm{Sr}_{\mathrm{i}}$ and ${ }^{87} \mathrm{Rb} /{ }^{86} \mathrm{Sr}$ displayed by feldspars from the Bandelier can be explained by either a long-lived magmatic system or crustal assimilation (Wolff and Ramos, 2003); however, variable $\mathrm{Pb}$ isotope signatures in these feldspars cannot be explained by radioactive decay at the $\mathrm{U} / \mathrm{Pb}$ ratios of the host magma (fig. 2; Wolff and Ramos, 2003). 
Therefore, in-situ radioactive decay in a closed-system magma chamber can be eliminated as a possible explanation of the isotopic heterogeneity in the Bandelier Tuff.

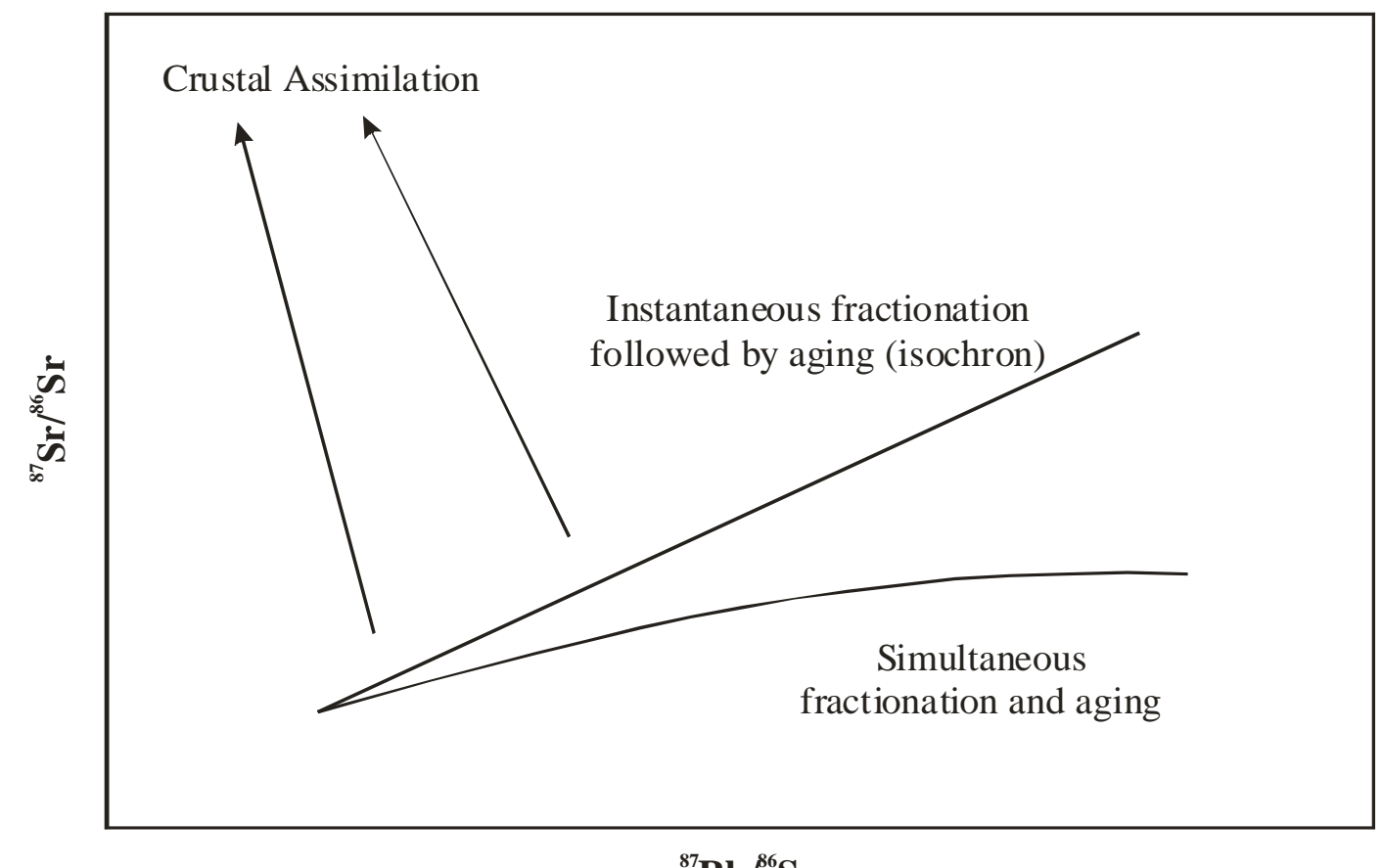

Fig. 1. Schematic variations of ${ }^{87} \mathrm{Sr} /{ }^{86} \mathrm{Sr}$ versus ${ }^{87} \mathrm{Rb} /{ }^{86} \mathrm{Sr}$ for three different process es that form distinct trends (modified after Wolff et al., 1999). 


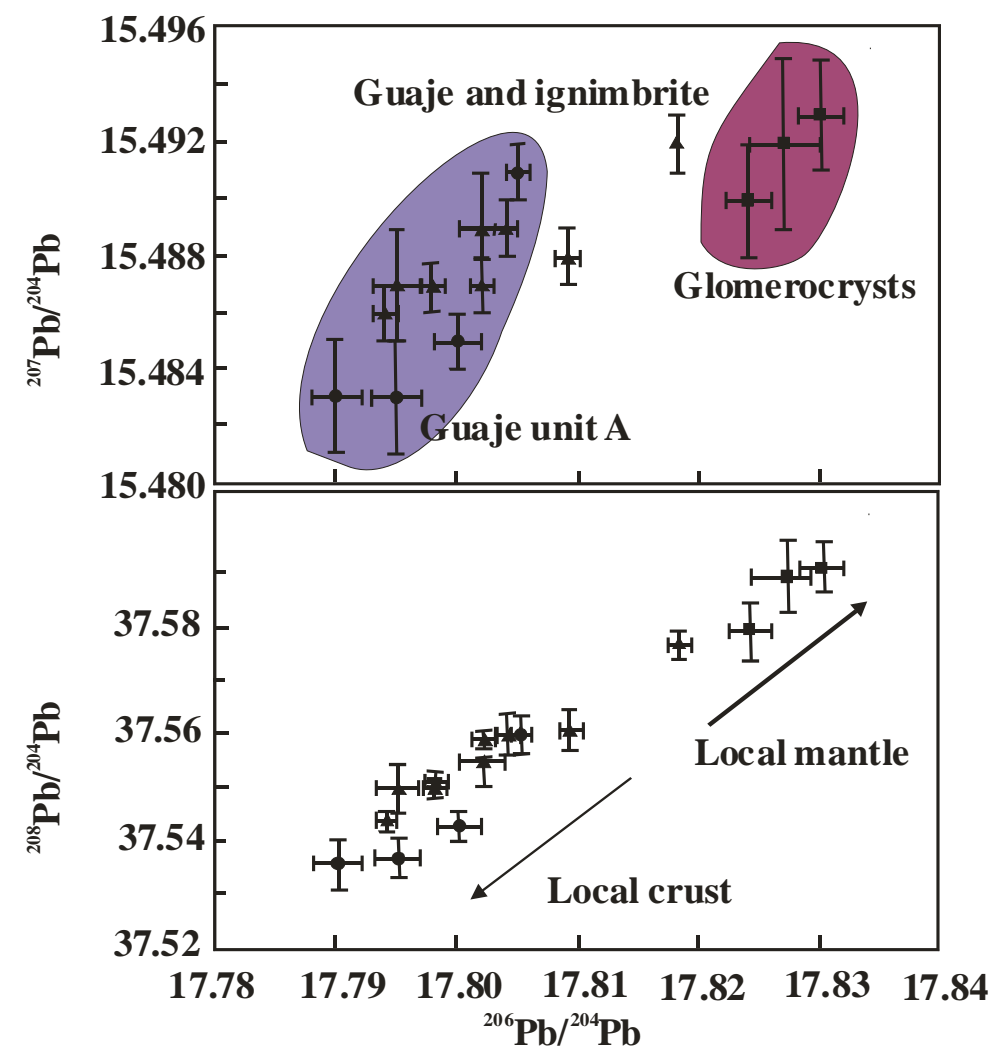

Fig. 2. Pb isotope ratios of single sanidines for Guaje unit $A$, Upper Guaje, and ignimbrite, and glomerocrysts from the Bandelier Tuff (modified after Wolff and Ramos, 2003). The Pb isotope variations could not be produced by in situ radioactive decay over reasonable time periods given the low U/Pb ratios of the host magma (Wolff and Ramos, 2003). Pb isotope ratios provide the most conclusive evidence for open system processes, arguing against a long-lived magma chamber.

\section{Fuji Volcano}

Although the eruptive history of Fuji Volcano has been dominated by basaltic volcanism, explosive silicic eruptions have occurred twice in the history of Fuji Volcano, in 2800BC and in 1707AD. These silicic eruptions are rare at Fuji Volcano and have been relatively little studied; hence, the petrogenetic processes that formed the chemical gradients in the magma chamber are poorly understood. Kawamoto (1990, 1991a, 1991b, 1992) proposed that liquid immiscibility played a major role in the formation of the 1707 chemically zoned magma chamber. However, his publications are limited to four abstracts; therefore, the detailed results of his studies are unavailable. 


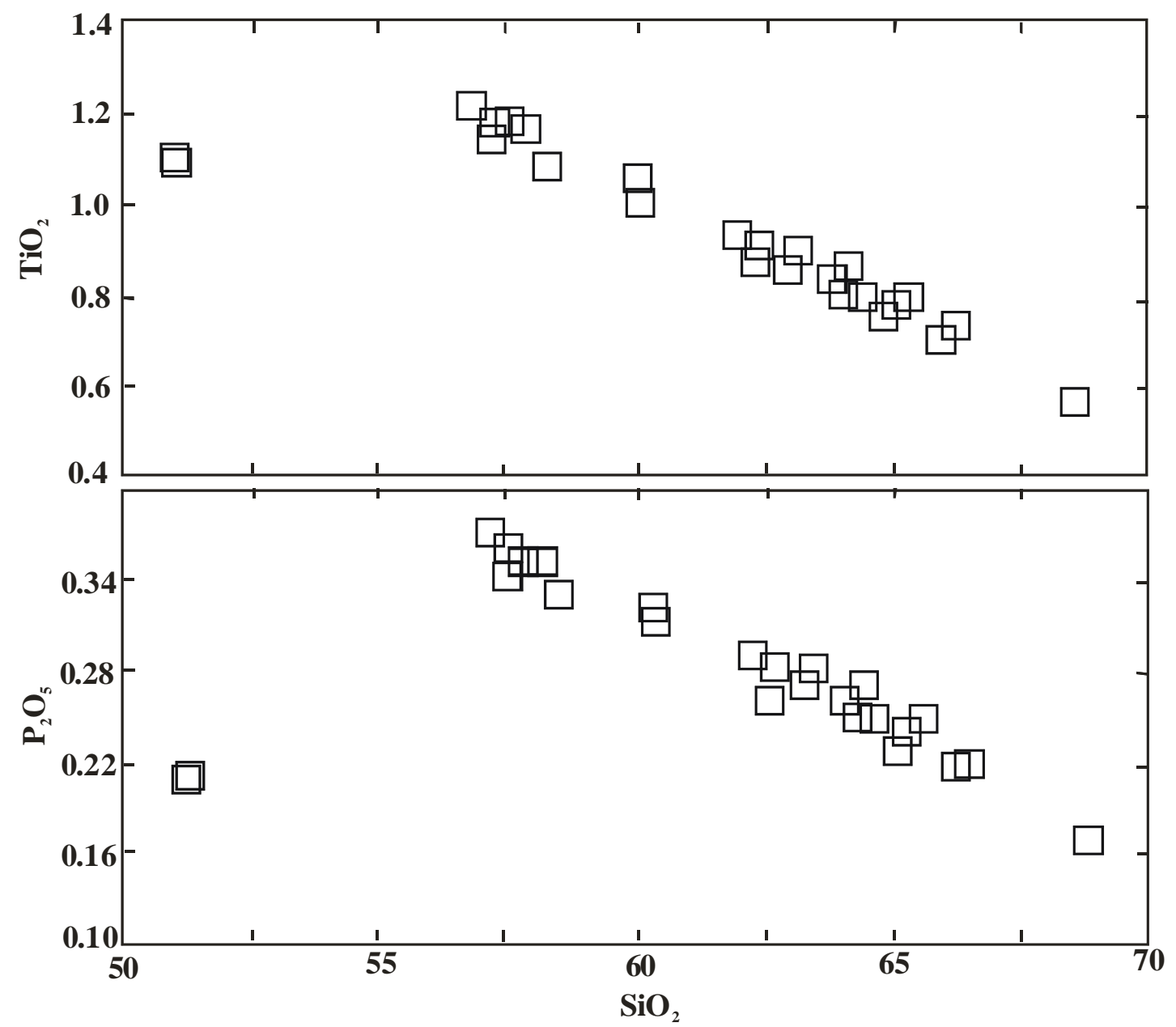

Fig. 3. $\mathrm{TiO}_{2}$ and $\mathrm{P}_{2} \mathrm{O}_{5}$ versus $\mathrm{SiO}_{2}$ for the Fuji 1707 samples (modified after Kawamoto, 1990). Both $\mathrm{TiO}_{2}$ and $\mathrm{P}_{2} \mathrm{O}_{5}$ decrease with increase in $\mathrm{SiO}_{2}$ from andesite to dacite.

Kawamoto (1990) analyzed twenty-seven pumice and scoria samples for petrography and whole rock major and trace element concentrations. Major element concentrations show substantial variations in $\mathrm{SiO}_{2}$ ranging from $~ 51$ to $\sim 68 \mathrm{wt} \%$ (fig. 3). Most of his samples are andesite and dacite, and a few are basalt. A compositional gap exists between basalt and dacite, from $\sim 51$ to $\sim 56$ wt\%. Both $\mathrm{TiO}_{2}$ and $\mathrm{P}_{2} \mathrm{O}_{5}$ decrease with increasing $\mathrm{SiO}_{2}$ from andesite to dacite. Based on the fact that the andesites do not fall on a mixing line between basalt and dacite, Kawamoto (1990) argued that magma mixing could be eliminated as a potential process for producing the chemical zonation. 
The 1707 eruptive materials were characterized into two types, basalt and andesite-dacite, based on petrography. The predominant phenocrysts in the basalts are olivine (2 vol\%) and feldspar (4 vol\%), while the andesites and dacites are aphyric with less than 1 vol\% feldspar, orthopyroxene, and clinopyroxene. Chemical compositions of pyroxene were reported to be identical in andesite and dacite, evidence used against the magmas being related by fractional crystallization or magma mixing (Kawamoto, 1990).

Chemical data, including a decrease in $\mathrm{TiO}_{2}$ and $\mathrm{P}_{2} \mathrm{O}_{5}$ with increasing $\mathrm{SiO}_{2}$ also were used to argue against crystal fractionation, because Kawamoto (1990) was unable to explain the chemical trends by fractionation of the observed mineral assemblage. Because neither hypersthene nor augite incorporate significant $\mathrm{TiO}_{2}$ and $\mathrm{P}_{2} \mathrm{O}_{5}$ into their structures, it was inferred that these oxides should have increased with increasing $\mathrm{SiO}_{2}$, if crystal fractionation of the observed mineral assemblage occurred (Kawamoto, 1990).

Homogeneous Magma Chamber
Zoned Magma Chamber

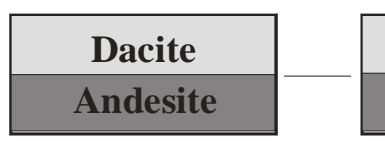

\section{Dacite}

Andesite

\section{Liquid \\ Immiscibility}

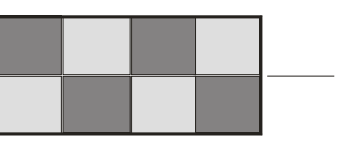

(1)

Fig. 4. Proposed liquid immiscibility model for the Fuji 1707 deposit (modified after Kawamoto, 1990, 1991a). According to Kawamoto's model, the 1707 magma chamber evolved through four main stages: 1) the presence of a homogeneous magma chamber; 2) the occurrence of liquid immiscibility; 3) the formation of a chemically zoned magma chamber; and 4) intrusion of basaltic magma.

According to Kawamoto (1990, 1991a, 1991b, 1992), liquid immiscibility can best explain the apparent limited trace element variations, limited temperature variations, identical phenocryst compositions, and identical Sr isotopic compositions. Based on the above observations, Kawamoto proposed that the 1707 magma chamber evolved through four main stages (fig. 4): 1) the presence of a homogeneous magma chamber; 2) separation into two liquids (andesite and dacite) by liquid immiscibility with a drop of the temperature; 3) density separation of andesitic and dacitic magmas to form a chemically zoned magma chamber; and 4) intrusion of 
basaltic magma into a pre-existing magma chamber. His model supposedly can explain the common features in calc-alkaline rocks (Kawamoto, 1991a, 1991b, 1992) including: 1) constant $\mathrm{FeO} / \mathrm{MgO}$ ratios during differentiation; 2) mafic inclusions in felsic rocks; and 3) compositional gaps between andesite and dacite/rhyolite.

\section{Liquid immiscibility}

Silicate liquid immiscibility is a process of magmatic differentiation, in which magma separates into two compositionally distinct immiscible silicate melts. Although liquid immiscibility was hypothesized by early experimental petrologists, (Greig, 1927; Bowen, 1928), it fell into disrepute until 1970 when the indisputable evidence of silicate liquid immiscibility was found in Apollo 11 lunar mare basalts (Roedder and Weiblen, 1970). Soon after the finding of the striking evidence in lunar mare basalts, Roedder and Weiblen (1971) and De (1974) found evidence for silicate liquid immiscibility in terrestrial basalts. Philpotts (1979) and Philpotts and Doyle (1983) observed evidence for silicate liquid immiscibility in Connecticut flood basalts and provided additional insights of silicate liquid immiscibility experimentally. Later, Fujii et al. (1980) observed a number of volcanic rocks from widely distributed localities in the Japanese Islands and also found evidence for silicate liquid immiscibility.

Silicate liquid immiscibility is common in high-alumina basalts and tholeiitic basalts as well as in andesites (Fujii et al., 1980). Although less common, evidence for silicate liquid immiscibility has also been found in some alkalic rocks (Fujii et al., 1980). The presence of dark-colored spherical globules within light-colored glass matrix (fig. 5) under a microscope provides petrographic evidence of liquid immiscibility. Some dark-colored globules are not spherical (Fujii et al., 1980) but rather elliptical, irregular blob or dumbbell shaped (De, 1974). De (1974) interpreted the non-spherical globules as spherical globules that were deformed while attaching to plagioclase crystals. In rare cases, light-colored glass globules are observed in darkcolored glass (Fujii et al., 1980). The average diameter of dark-colored (high-iron) globules is $0.004 \mathrm{~mm}$, typically ranging from 0.002 to $0.010 \mathrm{~mm}$ (De, 1974). Although silicate liquid immiscibility occurs during late stage crystallization (a few percent of remaining liquid; Philpotts, 1979), in rare cases, occurrences of liquid immiscibility in early stages of crystallization have been reported (Roedder and Weiblen, 1971; De, 1974). 


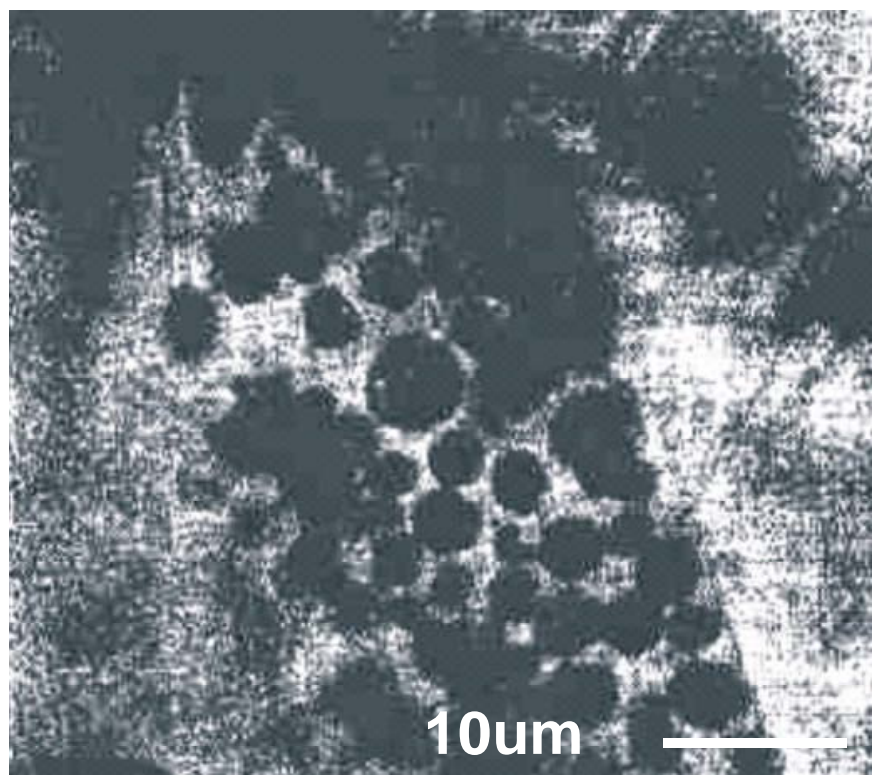

Fig. 5. Petrographic evidence for liquid immiscibility in an olivine basalt from the 864AD deposit of Fuji Volcano (modified after Fujii et al., 1980). These dark-colored globules in light-colored glass matrix are interpreted as evidence for liquid immiscibility.

De (1974) reported occurrences of silicate liquid immiscibility in basalts from the Deccan Traps, India. Through his detailed observations, he found evidence for silicate liquid immiscibility in approximately 50 percent of the total of 150 specimens. These specimens represent the Lower, Middle, and Upper stratigraphic subdivisions of the Deccan Traps and come from western India including Kutch, Bombay, and Daulatabad and Central India including Jabalpur, Nagpur, and Chindwara. These basalts are tholeiitic in composition and contain phenocrysts of olivine and plagioclase in a groundmass of plagioclase and augite.

Petrographic evidence showed the presence of dark-colored globules of glass in lighter colored glass. In addition, Cu-Fe sulfide globules were found in some specimens. High-silica glass globules in a base of darker colored high-iron glass such as those found in the lunar basalts were absent in the samples from Deccan Traps. The presence of $\mathrm{Cu}$-Fe sulfides is interpreted as coexistence of both silicate/sulfide liquid immiscibility and high-iron/high-silica liquid immiscibility (De, 1974). While the high-silica and high-iron glasses of the lunar mare basalts have compositions equivalent to potassic granite and pyroxenite respectively, the residual glasses in the Deccan Trap basalts commonly have compositions corresponding to a mixture of augite and magnetite. 
Silicate liquid immiscibility in a tholeiitic basalt flow in Connecticut was also reported (Philpotts, 1979; Philpotts and Doyle, 1983). In their studies, petrographic and textural characteristics of basalt were interpreted as evidence for silicate liquid immiscibility. Investigations were made on three well-exposed basaltic units ranging from highly amygdaloidal and altered, massive and fresh, and pillowed and slightly altered, from the lowest to the uppermost respectively. Evidence of silicate liquid immiscibility is present in the middle basalt. The presence of liquid immiscibility was difficult to observe under regular transmitted light, but it became apparent under reflected light. Both dark spheres and light spheres were found in respective glasses. The whole-rock chemistry of the host rocks shows that the basalts are common quartz normative tholeiites with a high ferrous/ferric iron ratio. The only unusual feature is the low potassium concentration with only half of typical theoleiitic potassium concentration.

In additional to the textural evidence, several experiments were conducted in order to constrain the factors that control liquid immiscibility (Philpotts, 1979; Philpotts and Doyle, 1983). These experiments documented that oxygen fugacity as well as oxidation state of the magma play a critical role in determining whether or not the liquid encounters the liquid immiscibility field.

Widespread occurrence of silicate liquid immiscibility has also been reported in Japanese volcanic rocks (Fujii et al., 1980), including samples from Fuji Volcano, Hakone Volcano, and Oshima Volcano. Olivine basalt and high-alumina basalt lava flows of Fuji Volcano display the most conspicuous evidence for liquid immiscibility, with dark-colored globules up to $0.010 \mathrm{~mm}$ in diameter. The composition of the dark globules was determined by electron probe microanalysis, which revealed that they have higher concentrations of $\mathrm{P}_{2} \mathrm{O}_{5}$ compared to those of lunar mare basalts. It is speculated that the concentration of $\mathrm{Fe}_{2} \mathrm{O}_{3}$ is also higher, but $\mathrm{Fe}$ concentrations could not be determined by microprobe analysis (Fujii et al., 1980).

Since the discovery of the indisputable evidence for silicate liquid immiscibility in lunar mare basalts, silicate liquid immiscibility has been widely recognized as a process of magmatic differentiation. The occurrence of two immiscible silicate melts in high-alumina basalts and tholeiitic basalts may be expected at low pressure during the late stages of crystallization. However, there are no examples of magma chamber scale silicate liquid immiscibility in Japanese or other volcanoes, arguing against silicate liquid immiscibility as a significant process 
in magma chamber-scale magmatic differentiation.

\section{Objectives of this study}

This study involves a comprehensive evaluation of the 1707 magma chamber of Fuji Volcano, Japan. Although Kawamoto (1990, 1991a, 1991b, 1992) proposed that liquid immiscibility played a major role in the formation of the 1707 chemically zoned magma chamber, liquid immiscibility has not previously been identified as a magma chamber-scale differentiation process in silicic systems. Because his work appears only in four abstract publications, the detailed results of his study are unavailable for further assessment. Therefore, in order to better constrain the petrogenetic processes that occurred prior to the 1707 eruption, petrographic and microprobe data, major and trace element data, and $\mathrm{Sr}, \mathrm{Nd}, \mathrm{Pb}$, and $\mathrm{Os}$ isotopic data were obtained. Table 1 summarizes the three most common petrogenetic processes that have been identified in the formation of chemically zoned magma chambers (Cameron, 1984; Wörner and Schmincke, 1984; Duffield et al., 1995; Christensen and Halliday, 1996; Wolff and Ramos, 2003) and the petrogenetic tracers that can be used to identify these processes.

Table 1. Summary of petrogenetic processes and indicators.

\begin{tabular}{|l|l|l|l|}
\hline Processes & \multicolumn{1}{|c|}{$\begin{array}{c}\text { Petrography \& } \\
\text { Microprobe }\end{array}$} & $\begin{array}{c}\text { Major and trace elements } \\
\text { systematics }\end{array}$ & \multicolumn{1}{|c|}{$\begin{array}{c}\text { Isotope (Sr, Nd, Pb } \\
\text { and Os) systematics }\end{array}$} \\
\hline $\begin{array}{l}\text { Crosed system } \\
\text { fractionation }\end{array}$ & & $\begin{array}{l}\text { *Variations in mineral } \\
\text { compositions with change in } \\
\text { magma compositions } \\
\text { *Systematic variations with } \\
\text { kinks in element-element plots } \\
\text { *Constant ratios of highly } \\
\text { incompatible elements }\end{array}$ & *Constant \\
\hline Magma mixing & $\begin{array}{l}\text { *Mingling, } \\
\text { *Reverse zoning } \\
\text { *Disequilibrium } \\
\text { textures }\end{array}$ & $\begin{array}{l}\text { *Linear correlations on all } \\
\text { element-element plots }\end{array}$ & $\begin{array}{l}\text { *Hyperbolic mixing } \\
\text { trends on isotope- } \\
\text { isotope plots }\end{array}$ \\
\hline $\begin{array}{l}\text { Crustal } \\
\text { assimilation }\end{array}$ & $\begin{array}{l}\text { *Disequilibrium } \\
\text { textures }\end{array}$ & $\begin{array}{l}\text { *Modified ratios of highly } \\
\text { incompatible elements }\end{array}$ & $\begin{array}{l}\text { *More radiogenic } \\
\text { signatures in evolved } \\
\text { magmas }\end{array}$ \\
\hline
\end{tabular}




\title{
Chapter 3
}

\section{The Evolution of a Chemically Zoned Magma Chamber: the 1707 eruption of Fuji Volcano, Japan}

\begin{abstract}
Detailed petrographic, major and trace element and $\mathrm{Sr}, \mathrm{Nd}, \mathrm{Pb}$, and $\mathrm{Os}$ isotope studies were done in order to constrain the petrogenetic processes that formed a chemically zoned magma chamber prior to the 1707 eruption of Fuji Volcano. The eruptive history of Fuji Volcano has been dominated by basaltic volcanism. However, the 1707 eruption of Fuji Volcano resulted in a chemically zoned volcanic deposit ranging from basalt to dacite. The processes responsible for generating these siliceous magmas beneath Fuji Volcano are not well understood although it has been proposed that liquid immiscibility played a major role (Kawamoto, 1992). Other possible explanations for a chemically zoned volcanic deposit include magma mixing, crystal fractionation, and crustal assimilation. Our observed petrography, chemical variations and isotopic compositions can be explained by crystal fractionation accompanied by minor crustal assimilation.
\end{abstract}




\section{Introduction}

Most deposits from large, explosive volcanic eruptions are chemically zoned, representing chemical gradients in the magma chamber feeding the volcano. Magma generally becomes more silicic and volatile-rich towards the top of the chamber as it evolves, becoming potentially explosive. However, the processes generating such complex magma chambers are still being debated. Although closed system crystal fractionation can often produce observed chemical gradients (Michael, 1983; Wörner and Schmincke, 1984; Widom et al., 1992), several recent detailed geochemical and isotopic studies have revealed the importance of open system processes such as magma mixing and crustal assimilation in some cases (Wörner and Wright, 1984; Duffield et al., 1995; Wolff and Ramos, 2003).

The most recent eruption of Fuji Volcano, in 1707AD, resulted in a chemically zoned volcanic deposit ranging from basalt to dacite. Such silicic eruptions have only occurred twice in the history of Fuji Volcano, in 2800BP and in 1707AD; most eruptions throughout Fuji's history have been dominated by basalt. Despite the unusual nature of the 1707 eruption, relatively little work has been done to unravel the processes that led to the silicic, chemically zoned deposit. Kawamoto (1992) proposed that liquid immiscibility was an important process in generating a chemically zoned magma chamber prior to the 1707 eruption. Kawamoto's model was based on four main observations of the 1707 deposit: 1) limited trace element abundance variations; 2) limited temperature variations; 3) identical phenocryst compositions; and 4) identical Sr isotopic compositions throughout the deposit. However, Kawamoto's work has been published only in abstract form, hence detailed assessment of the liquid immiscibility model is precluded. Although liquid immiscibility may be common in some mafic magmas such as high-alumina and tholeiitic basaltic magmas, it is only known to occur on a small scale (Fujii et al., 1980). Liquid immiscibility has not previously been recognized as a process that could produce magma chamber-scale chemical gradients or silicic magmas such as andesite and dacite.

The purpose of this study was to carefully evaluate the role of potential petrogenetic processes including crystal fractionation, magma mixing, crustal assimilation, and liquid immiscibility, in the development of the chemically zoned 1707 deposit of Fuji Volcano. Petrographic, major and trace element, and $\mathrm{Sr}, \mathrm{Nd}, \mathrm{Pb}$, and $\mathrm{Os}$ isotope data have been combined to develop a detailed petrogenetic model of the evolution of the Fuji 1707 magmatic system. 


\section{Geological setting/ background}

Fuji Volcano is located in south-central Honshu, Japan, lying over the westward subducting Pacific plate, and possibly influenced by the Phillipine Sea plate (fig.1). The main edifice of Fuji Volcano consists of three volcanoes including Komitake, Older Fuji, and Younger Fuji (oldest to youngest, respectively). The oldest known deposits from Fuji formed approximately 80,000 years ago (Takahashi et al., 1991). Fuji volcano has been very active throughout its history, and erupted predominantly medium $\mathrm{K}$ series and high alumina basalts with $\mathrm{SiO}_{2}$ ranging from 48 to $52 \mathrm{wt} \%$ (Togashi, 1990). $\mathrm{Sr}$ and $\mathrm{Nd}$ isotope signatures in Fuji eruptive products display a relatively narrow range with ${ }^{87} \mathrm{Sr} /{ }^{86} \mathrm{Sr}$ varying from 0.70335 to 0.70355 and ${ }^{143} \mathrm{Nd} /{ }^{144} \mathrm{Nd}$ varying from 0.51300 to 0.51305 (Togashi, 1990). These values fall within the range of typical depleted island arc basalts (Togashi, 1990).

The most recent eruption in 1707AD was one of the most explosive eruptions in the history of Fuji Volcano and resulted in a chemically zoned volcanic deposit ranging from basalt to dacite. The Plinian eruption associated with the large-scale pumice, scoria, and volcanic tephra lasted for a little over two weeks, forming three craters on the SW flank of the volcano. These craters are called first, second, and third craters from the top to the bottom. Silicic eruptions took place at the second and third craters, and later basaltic eruptions took place at the first crater. The total eruptive volume was $0.7 \mathrm{~km}^{3}$ (Weather Observatory, 2001).

\section{Analytical techniques}

A comprehensive suite of samples for this study was collected from two localities. The 1707 deposit has previously been subdivided into four fall units, Ho I to Ho IV from the bottom to the top, based on differences in grain size and constituents (Miyaji, 1984). The first sampling locality, $4.5 \mathrm{~km} \mathrm{SE}$ of the craters $\left(35^{\circ} 19^{\prime} 883^{\prime \prime} \mathrm{N}, 138^{\circ} 47^{\prime} 831^{\prime \prime} \mathrm{E}\right)$ exhibits an incomplete eruption record, with an absence of Ho III and Ho IV, but greater thicknesses of Ho I $(22 \mathrm{~cm})$ and Ho II $(100 \mathrm{~cm})$. The second sampling site, $4 \mathrm{~km} \mathrm{NE}$ of the craters $\left(35^{\circ} 21^{\prime} 703^{\prime \prime} \mathrm{N}, 1^{\circ} 8^{\circ} 47^{\prime} 035^{\prime \prime} \mathrm{E}\right)$, displays a complete depositional section of the 1707 eruption (fig. 2). The thicknesses of the representative units at this site are $18,19,115,125 \mathrm{~cm}$.

Major and trace element concentrations of whole rocks were obtained by DCP-AES (Direct-Current Plasma Atomic Emission Spectrometry) at Miami University. For the rare earth element (REE) measurements, bulk REE separations were done by ion exchange with AG50W- 
X8 cation exchange resin, followed by cleanup columns with AG50W-X12 resin. Sample preparation and measurement methods are described in Katoh et al. (1999). Mineral chemistry was obtained by electron microprobe analysis (Cumeca SX 50) at Indiana University, Bloomington, IN.

Chemical separations and $\mathrm{Sr}, \mathrm{Nd}, \mathrm{Pb}$, and $\mathrm{Os}$ isotopic measurements were done at Miami University. For $\mathrm{Sr}, \mathrm{Nd}$, and $\mathrm{Pb}$ analyses, approximately $0.1 \mathrm{~g}$ of whole rock powder was dissolved in concentrated $\mathrm{HF}-\mathrm{HNO}_{3}$ and taken up in $\mathrm{HBr}$. Procedures for the separation are described in Walker et al. (1989) with the exception of Sm-Nd separations. EiChrom Ln-Spec resin was used for Sm-Nd separations following methods similar to Pin and Zalduegui (1997).

Sample digestion for Re-Os chemistry followed the Carius tube method described in Shirey and Walker (1995). Separation of Re and Os were done using an aqua regia-CCl $\mathrm{Cl}_{4}$ solvent extraction technique (Cohen and Waters, 1996). The Os was back-extracted into $\mathrm{HBr}$ and purified using a microdistillation procedure (Roy-Barman, 1993; Roy-Barman and Allegre, 1995).

All isotopic compositions were measured by thermal ionization mass spectrometry using a Finnigan Triton. Strontium isotopic ratios were corrected for fractionation using ${ }^{86} \mathrm{Sr} /{ }^{88} \mathrm{Sr}$ $=0.1194$. Eighty measurements of NBS 987 gave an average of ${ }^{87} \mathrm{Sr} /{ }^{86} \mathrm{Sr}=0.71024 \pm 1(2 \sigma)$. Neodymium isotopic ratios were corrected for fractionation using ${ }^{144} \mathrm{Nd} /{ }^{146} \mathrm{Nd}=0.7219$. Fifty measurements of La Jolla gave an average of ${ }^{143} \mathrm{Nd} /{ }^{144} \mathrm{Nd}=0.51185 \pm 1(2 \sigma) .{ }^{206} \mathrm{~Pb} /{ }^{204} \mathrm{~Pb}$, ${ }^{207} \mathrm{~Pb} /{ }^{204} \mathrm{~Pb}$, and ${ }^{208} \mathrm{~Pb} /{ }^{204} \mathrm{~Pb}$ were corrected for fractionation by $0.1 \%, 0.1 \%$, and $0.125 \%$ per amu respectively. Errors on ${ }^{206} \mathrm{~Pb} /{ }^{204} \mathrm{~Pb},{ }^{207} \mathrm{~Pb} /{ }^{204} \mathrm{~Pb}$, and ${ }^{208} \mathrm{~Pb} /{ }^{204} \mathrm{~Pb}$ measurements were \pm 0.006 , \pm 0.008 , and \pm 0.026 respectively. Internal measurement errors for osmium isotopic ratios ranged from $0.5-2 \%$. Blank correction errors ranged from $0.6-10 \%$ based on blanks of $1.0 \pm 0.1 \mathrm{pg}$ and ${ }^{187} \mathrm{Os} /{ }^{188} \mathrm{Os}=0.174$. Replicate analyses $\left(\mathrm{JF}-15\right.$ and JF-15R) agreed within $3.6 \%$ for ${ }^{187} \mathrm{Os} /{ }^{188} \mathrm{Os}$.

\section{Results}

Chemical compositions of thirty-seven juvenile and twelve crustal xenolith samples were analyzed using DCP-AES (table 1). JF-20 and JF-21 are heterogeneous with mixture of pumices and scorias. In order to get meaningful whole rock chemistry, JF-20 was separated into dark (JF20D) and light (JF-20L) fractions, while JF-21 was separated into dark (JF-21D), light (JF-21L), very light (JF-21V), and banded (JF-21B) fractions. All juvenile samples are medium-K 
subalkaline basalt, andesite, and dacite respectively (fig. 3).

\section{Major elements}

The juvenile samples from the 1707 deposit shows substantial major element variations. $\mathrm{SiO}_{2}$ ranges from 50 to $67 \mathrm{wt} \%$ (basalt to dacite); however, there is a compositional gap between 52 to $57 \mathrm{wt} \%$. $\mathrm{TiO}_{2}, \mathrm{Al}_{2} \mathrm{O}_{3}, \mathrm{Fe}_{2} \mathrm{O}_{3}, \mathrm{MnO}, \mathrm{MgO}, \mathrm{CaO}$, and $\mathrm{P}_{2} \mathrm{O}_{5}$ decrease with increasing $\mathrm{SiO}_{2}$, while $\mathrm{Na}_{2} \mathrm{O}$ and $\mathrm{K}_{2} \mathrm{O}$ increase with increasing $\mathrm{SiO}_{2}$. Concentrations of $\mathrm{Al}_{2} \mathrm{O}_{3}, \mathrm{Fe}_{2} \mathrm{O}_{3}, \mathrm{MgO}, \mathrm{CaO}$, $\mathrm{Na}_{2} \mathrm{O}$, and $\mathrm{K}_{2} \mathrm{O}$ vary by $\sim 2$ to $7.5 \mathrm{wt} \%$, while $\mathrm{TiO}_{2}, \mathrm{MnO}$, and $\mathrm{P}_{2} \mathrm{O}_{5}$ vary by less than $1 \mathrm{wt} \%$ (table 1).

Systematic variations are observed between elemental abundance and relative depth in the deposit (fig. 4). The deposit generally becomes more mafic from the bottom to the top, although as noted above, same samples from individual stratigraphic horizons are heterogeneous. Although the deposit is predominantly basaltic, andesite and dacite are still distinguishable at the bottom of the deposit based on their color.

\section{Trace elements}

Trace elements analyzed by DCP-AES include $\mathrm{Ni}, \mathrm{Zn}, \mathrm{Cu}, \mathrm{Cr}, \mathrm{Zr}, \mathrm{V}, \mathrm{Sc}, \mathrm{Ba}, \mathrm{Sr}, \mathrm{Rb}$, and $\mathrm{Y}$ (table 1). All trace elements vary in concentration throughout the deposit. $\mathrm{Ni}, \mathrm{Zn}, \mathrm{Cu}, \mathrm{Cr}, \mathrm{V}$, $\mathrm{Sc}$, and $\mathrm{Sr}$ decrease with increasing $\mathrm{SiO}_{2}$, while $\mathrm{Zr}, \mathrm{Ba}, \mathrm{Rb}$, and $\mathrm{Y}$ increase with increasing $\mathrm{SiO}_{2}$. Trace element concentration variations range in magnitude from $<3$-fold ( $\mathrm{Zn}, \mathrm{Zr}, \mathrm{Ba}, \mathrm{Y}, \mathrm{Sr}$ ) to $>5$-fold ( $\mathrm{Ni}, \mathrm{Cr}, \mathrm{Rb}$ ). Intermediate (3-5 fold) variations are observed for $\mathrm{Cu}, \mathrm{V}$, and $\mathrm{Sc}$.

REE abundances increase from basalt to andesite. There is slight increase in light REE (LREE) and no increase in heavy REE (HREE) from andesite to dacite and from the least evolved to more evolved dacite (table 2; fig. 5). Negative Eu anomalies are absent in the basalts, but increase in magnitude from andesite to more evolved dacite.

\section{Petrography}

The scorias and pumices from the 1707 deposit share some common characteristics: all are vesicular and porphyritic/vitrophyric. From the least evolved to more evolved samples, the amount of glassy matrix increases and the percentage of phenocrysts decreases from $<10$ to $<2$ vol\% (basalt to dacite). Some plagioclase and olivine phenocrysts show evidence of 
disequilibrium including sieved and resorbed textures (fig. 6).

\section{Basalt}

Basalts are the most abundant rock type in the 1707 deposit. Some basalts display diktytaxitic texture. Predominant mineral phases in basalt are plagioclase, olivine, augite and FeTi oxide. Two characteristic matrices observed are dark black quenched matrix and light dark highly vesicular matrix. Relatively larger phenocrysts $(<2000 \mathrm{um})$ are often associated with the former matrix, while relatively smaller phenocrysts $(<750 \mathrm{um})$ are observed in the latter matrix.

\section{Andesite}

The andesitic pumices display a variety of colors from white to dark, and some are banded. Phenocryst phases observed in andesite are plagioclase, hypersthene, augite, and Fe-Ti oxide. Although light and dark bands are visible in pumices under the microscope, there is no significant change in the mineral phases in different colored bands.

\section{Dacite}

The dacitic pumices display a variety of colors from white to light-gray, and some are banded. Although phenocryst phases in the dacites are the same as those in the andesite, the dacites have fewer phenocrysts.

\section{Crustal xenoliths}

Two types of crustal xenoliths are found at the sampling sites, including basalts and gabbros. The basalts are gray in color and some are vesicular. The phenocryst assemblage in the basalt xenoliths is the same as that in the 1707 basalts. The size of the phenocrysts in the basalt xenoliths are relatively larger ( $<2000 \mathrm{um})$, and euhedral to subhederal phenocrysts are ubiquitous. The gabbro xenoliths are very light in color, and consist primarily of anorthite (up to $90 \mathrm{vol} \%$ ) with very few mafic phases. 
Mineral chemistry

Representative samples spanning the range of chemical compositions in the 1707 deposit were analyzed for mineral chemistry by electron microprobe. Average chemical compositions of representative feldspar, olivine, hypersthene, augite, and Fe-Ti oxide are summarized in table 3.

Plagioclases are the most abundant phenocrysts throughout the deposit, and range in size from $50 \mu \mathrm{m}$ (microphenocrysts) to $2000 \mu \mathrm{m}$. Plagioclases in basalt show a wide range in compositions varying from An $70-90$ (fig. 7). In general, the plagioclases decrease in Ca content from core to rim (An $80-76)$. Plagioclase phenocrysts in andesite range from $\mathrm{An}_{85-90}$, while microphenocrysts are much more sodic $\left(\mathrm{An}_{59-63}\right)$. Anorthite values typically decrease from core to rim. Plagioclase phenocrysts in dacite are much less calcic than those in andesite, ranging from An 69-53.

Olivine is present only in basalt. Olivine is Mg-rich, ranging from Fo 70-79. In the more evolved samples (andesite and dacite), olivine is absent and hypersthene is ubiquitous. The hypersthenes are very distinct with green to light brown pleochroism. Augite is a common phase throughout the 1707 deposit. There is no significant difference in chemical compositions of hypersthene and augite from andesite to dacite. Fe-Ti oxides are ubiquitous throughout the 1707 deposit.

Isotope variations

$\mathrm{Sr}, \mathrm{Nd}$, and $\mathrm{Pb}$ isotopic compositions of six representative juvenile and six crustal xenolith (basalt and gabbro) samples are summarized in table 4. All samples show identical isotopic signatures with ${ }^{87} \mathrm{Sr} /{ }^{86} \mathrm{Sr}=0.70341 \pm 1$ and ${ }^{143} \mathrm{Nd} /{ }^{144} \mathrm{Nd}=0.51304 \pm 1$, falling within the typical range for eruptive products from Fuji Volcano. All samples also show nearly identical $\mathrm{Pb}$ signatures with ${ }^{206} \mathrm{~Pb} /{ }^{204} \mathrm{~Pb}=18.27 \pm 3,{ }^{207} \mathrm{~Pb} /{ }^{204} \mathrm{~Pb}=15.51 \pm 1$, and ${ }^{208} \mathrm{~Pb} /{ }^{204} \mathrm{~Pb}=38.19 \pm 4$. The only $\mathrm{Pb}$ isotopic value reported from Fuji Volcano previously is that for JB 3 (Geological Survey of Japan reference). JB 3 is a basalt from the 864 AD eruption, and is similar to the 1707 samples with ${ }^{206} \mathrm{~Pb} /{ }^{204} \mathrm{~Pb}=18.27 \pm 3,{ }^{207} \mathrm{~Pb} /{ }^{204} \mathrm{~Pb}=15.52 \pm 1$, and ${ }^{208} \mathrm{~Pb} /{ }^{204} \mathrm{~Pb}=38.18 \pm 5$ (Geological Survey of Japan reference).

All samples fall just outside of the Pacific MORB field on ${ }^{143} \mathrm{Nd} /{ }^{144} \mathrm{Nd}$ versus ${ }^{87} \mathrm{Sr} /{ }^{86} \mathrm{Sr}$ and ${ }^{206} \mathrm{~Pb} /{ }^{204} \mathrm{~Pb}$ versus ${ }^{87} \mathrm{Sr} /{ }^{86} \mathrm{Sr}$ diagrams, while they fall within the Pacific MORB field on the ${ }^{207} \mathrm{~Pb} /{ }^{204} \mathrm{~Pb}$ versus ${ }^{206} \mathrm{~Pb} /{ }^{204} \mathrm{~Pb}$ diagram (fig. 8). 
The Os isotopic compositions of five representative juvenile samples were also measured (table 5). The two basalts show the least radiogenic signatures, with ${ }^{187} \mathrm{Os} /{ }^{188} \mathrm{Os}$ ranging from 0.165 to 0.174 (fig. 9). These values are slightly elevated compared to mantle-derived basalts from mid-ocean ridges and ocean islands (0.13-0.15; Widom, 1997; Shirey and Walker, 1998) but fall within the range of other arc basalts and sub-arc mantle xenoliths (0.13-0.17; Widom et al., 2003a; Widom et al., 2003b). The more evolved samples (one andesite and two dacites) display radiogenic signatures with ${ }^{187} \mathrm{Os} /{ }^{188} \mathrm{Os}$ ranging from 0.26 to 0.39 .

\section{Discussion}

Major and trace element variations

Major and trace elements show substantial variations throughout the deposit (fig. 3, 4). $\mathrm{SiO}_{2}$ ranges from 50 to $67 \mathrm{wt} \%$. Other major elements vary by $\sim 2$ to $7.5 \mathrm{wt} \%$, with the exception of $\mathrm{TiO}_{2}, \mathrm{MnO}$, and $\mathrm{P}_{2} \mathrm{O}_{5}$, which vary by less than $1 \mathrm{wt} \%$. Most of the trace elements show $>3$-fold variations, although $\mathrm{Zn}, \mathrm{Zr}$, and $\mathrm{Ba}$ display $<3$-fold variations.

The decrease in $\mathrm{TiO}_{2}, \mathrm{Al}_{2} \mathrm{O}_{3}, \mathrm{Fe}_{2} \mathrm{O}_{3}, \mathrm{MnO}, \mathrm{MgO}, \mathrm{CaO}$, and $\mathrm{P}_{2} \mathrm{O}_{5}$ with increasing $\mathrm{SiO}_{2}$ is suggestive of crystal fractionation (fig. 10). Elemental variation diagrams show non-linear trends over entire $\mathrm{SiO}_{2}$ range, indicating changes in fractionating mineral assemblage (fig. 10). These non-linear trends argue against magma mixing as a dominant process in generating the zonation in the 1707 magma chamber; magma mixing would result in linear trends on all element-element variation diagrams. Furthermore, the REE abundances of the andesites do not fall between those of basalt and dacite, indicating that andesite was not formed by mixing of basalt and dacite (fig. 5).

Least squares major element modeling was done using Igpet 2000. The whole-rock and mineral chemistry used in the major element modeling are summarized in tables 1 and 2 respectively. Closed system crystal fractionation was modeled in three steps, in accordance with the apparent changes in fractionating mineral assemblages suggested by the element-element variation diagrams (fig. 10), from basalt to andesite, andesite to dacite, and less evolved to more evolved dacite. The results of the major element modeling are summarized in tables 6 and 7 .

From basalt to andesite, $45.8 \%$ fractionation of plagioclase $(55.6 \%)$, augite $(22.2 \%)$, olivine $(12.1 \%)$, and $\mathrm{Fe}-\mathrm{Ti}$ oxide $(10.1 \%)$ reproduce the observed chemical compositions of andesite. From andesite to dacite, $26.9 \%$ fractionation occurred with a slightly different 
fractionating mineral assemblage including plagioclase (60.4\%), hypersthene (21.7\%), Fe-Ti oxide $(10.7 \%)$, augite $(6.6 \%)$, and apatite $(0.6 \%)$. From the least evolved to most evolved dacite, $17.2 \%$ fractionation took place with the same fractionating assemblage, but different relative proportions: plagioclase $(67.4 \%)$, hypersthene (13.7\%), augite $(8.8 \%)$, Fe-Ti oxide $(9.1 \%)$, and apatite (1\%). Figure 10 illustrates variations in $\mathrm{MgO}, \mathrm{CaO}$, and $\mathrm{FeO}$ versus $\mathrm{SiO}_{2}$ along with the major element modeling results. The high degree of fit between observed and modeled liquid compositions are indicated by the extremely low sum of squares of residual $(0.100,0.329$, and 0.073 for the three respective fractionation steps).

The major element modeling results are consistent with the observed mineral assemblages, as described previously. Although there is no definitive evidence of apatite in thin section, a few very small $(\sim 50 \mu \mathrm{m})$ crystals resembling apatite were observed petrographically and by cathodoluminescence microscopy in andesite and dacite. These crystals have high relief and pseudo-hexagonal shape with apparent zoning and bright orange-red luminescence. Additional evidence for the presence of apatite is provided by major element variations and REE abundance data. $\mathrm{P}_{2} \mathrm{O}_{5}$ decreases with increasing $\mathrm{SiO}_{2}$ from andesite to dacite, indicating that some mineral phase is pulling phosphorous out of the system, consistent with apatite fractionation (fig. 11). The slight increase in LREE and lack of increase in HREE from andesite to dacite and least- to most-evolved dacite (fig. 5) further supports the fractionation of trace amounts of apatite, because apatite strongly incorporates REE, particularly the middle REE. The chemical composition for apatite used in the major element modeling was based on average values of 475 samples from apatite in felsic-intermediate rocks not associated with ore-deposits (F-NA OD; Piccoli and Candela, 2002).

The relative mineral proportions and percentages of crystal fractionation obtained from the major element modeling with Igpet 2000 were applied to trace element modeling (table 8). The mineral-liquid Kd values were taken from Wilson (1989) and the GERM website. The trace element modeling results are consistent with the major element modeling, with variations in trace element concentrations consistent with changing bulk $\mathrm{D}$ values for each fractionation step. As fractionation proceeds, the bulk $\mathrm{D}$ values of $\mathrm{Sr}$ change from 1.03 to 1.56 to 2.02 (fig. 12). $\mathrm{Ba}$ and $\mathrm{Zr}$ are both incompatible elements, increasing with increasing $\mathrm{SiO}_{2}$ (fig. 12). Bulk D values of $\mathrm{Ba}$ change from 0.15 to 0.46 to 0.63 , while bulk $\mathrm{D}$ values of $\mathrm{Zr}$ change from 0.04 to 0.55 to 0.75 as fractionation proceeds. The modeling results also are consistent with observed REE 
variations (fig. 13). All models reproduce observed liquid compositions within analytical error or just outside of the error, further indicating the consistency of the major and trace element modeling. The major and trace element modeling results suggest that crystal fractionation played a major role in the development of chemical zonation in the Fuji 1707 magma chamber.

\section{$\mathrm{Sr}-\mathrm{Nd}-\mathrm{Pb}$ isotope systematics}

All juvenile and xenolith samples show identical isotopic signatures with ${ }^{87} \mathrm{Sr} /{ }^{86} \mathrm{Sr}$ of $0.70341 \pm 1$ and ${ }^{143} \mathrm{Nd} /{ }^{144} \mathrm{Nd}$ of $0.51304 \pm 1$, falling within the typical range for eruptive products from Fuji Volcano (Togashi, 1990). All samples also show nearly identical Pb isotopic signatures with ${ }^{206} \mathrm{~Pb} /{ }^{204} \mathrm{~Pb}$ of $18.27 \pm 3,{ }^{207} \mathrm{~Pb} /{ }^{204} \mathrm{~Pb}$ of $15.51 \pm 1$, and ${ }^{208} \mathrm{~Pb} /{ }^{204} \mathrm{~Pb}$ of $38.19 \pm 4$, which are very similar to the $864 \mathrm{AD}$ basalt. These observations are consistent with the Fuji 1707 chemical zonation being produced by closed system crystal fractionation. The mixing curve between the juvenile samples and typical Japanese upper crust (fig. 8) indicates that $\leq 0.2 \%$ assimilation of typical Japanese upper crust could be accommodated.

Evidence for open system behavior

Although closed system crystal fractionation can explain the observed major and trace element variations, petrographic features such as sieved/resorbed plagioclase and olivine phenocrysts (fig. 6) can result from open system process such as crustal contamination, that may have taken place prior to the 1707 eruption.

In order to better constrain the potential role of crustal assimilation, the Os isotope system was utilized. Os isotopes are generally much more sensitive to crustal assimilation than are the $\mathrm{Sr}, \mathrm{Nd}$, and $\mathrm{Pb}$ systems, due to the extreme difference in ${ }^{187} \mathrm{Os} /{ }^{188} \mathrm{Os}$ between mantle and crust (Widom et al., 1996; Shirey and Walker, 1998; Widom et al., 1999). The ${ }^{187} \mathrm{Os} /{ }^{188} \mathrm{Os}$ signature of the andesite and dacites (0.26-0.39) are distinctly more radiogenic than those of the basalts (0.165-0.174), indicating that crustal assimilation played a role in the formation of the chemically zoned magma chamber. Mixing calculations for assimilation of typical upper crust $\left({ }^{187} \mathrm{Os} /{ }^{188} \mathrm{Os}\right.$ of $\sim 1.0$; Peucker-Ehrenbrink and Jahn, 2001) by Fuji magmas indicate the radiogenic signatures observed in the more evolved Fuji samples can be explained by $\leq 0.2 \%$ of crustal assimilation (fig. 9), which would not cause significant variation in $\mathrm{Sr}$ and $\mathrm{Nd}$ isotopes. The basement rocks beneath Fuji (Tertiary marine sediments and green volcanic tuffs; Miyaji, 
1990) are likely assimilants, but chemical and isotopic compositions are unavailable.

\section{Proposed model}

The petrography, major and trace element systematics, and $\mathrm{Sr}, \mathrm{Nd}, \mathrm{Pb}$, and $\mathrm{Os}$ isotope results suggest that the 1707 chemically zoned magma chamber of Fuji Volcano evolved through three main stages including: 1) fractionation of parental magma; 2) formation of an evolved, chemically zoned magma chamber; and 3) basaltic intrusion into the magma chamber. Figure 14 illustrates each stage as a cartoon diagram.

\section{Stage I: fractionation of parental magma}

Because Fuji has erupted almost exclusively basaltic magmas throughout its history, it is inferred that the first stage involved crystal fractionation of basaltic parental magma. The compositional gap between basalt and andesite may indicate that the 1707 basalt is not directly related to the 1707 andesite and dacite. However, it is assumed that the chemical composition of basaltic parental magma that fractionated to form the silicic magmas was similar to the 1707 basalt, based on the chemical similarity of basalts erupted from Fuji Volcano throughout its history (Takahashi et al., 1991). Major, trace, and REE modeling are consistent with $45.8 \%$ crystal fractionation of plagioclase (55.6\%), augite (22.2\%), olivine (12.1\%), and Fe-Ti oxide (10.1\%) from basalt to andesite (fig. 10).

\section{Stage II: formation of a chemically zoned magma chamber}

During the second stage, crystal fractionation continued within the magma chamber; $26.9 \%$ fractionation of andesite with a crystallizing assemblage of plagioclase (60.4\%), hypersthene $(21.7 \%)$, Fe-Ti oxide $(10.7 \%)$, augite $(6.6 \%)$, and apatite $(0.6 \%)$ produced the least evolved dacitic magma. Further crystal fractionation formed more evolved dacitic magma; $17.2 \%$ fractionation of plagioclase (67.4\%), hypersthene (13.7\%), augite (8.8\%), Fe-Ti oxide (9.1\%), and apatite (1\%) can explain the chemical compositions of the most evolved samples from the 1707 deposit. During stage II, a minor amount of crustal assimilation occurred. The assimilation is consistent with the sieved/resorbed textures in some plagioclase and olivine phenocrysts, which indicate that the crystals experienced chemical disequilibrium during their

evolution. In addition, minor crustal assimilation is required to explain the elevated ${ }^{187} \mathrm{Os} /{ }^{188} \mathrm{Os}$ 
signatures in the more evolved samples. The small amount of assimilation would not be expected to significantly affect the major and trace elements or the $\mathrm{Sr}, \mathrm{Nd}$, and $\mathrm{Pb}$ isotope signatures.

\section{Stage III: basaltic intrusion into the magma chamber}

The compositional gap between basalt and andesite suggests that during the final stage, basaltic magma was intruded into a pre-existing silicic magma chamber consisting of andesite and dacite. The basaltic intrusion may have triggered the explosive 1707 eruption. Based on the relative erupted volumes, the amount of basaltic magma intruded into the magma chamber was likely much greater than the volume of evolved magma in the magma chamber. These three stages can explain the observed chemically zoned volcanic deposit of 1707 eruption of Fuji Volcano.

\section{Liquid Immiscibility}

Although liquid immiscibility is a common small-scale process in basaltic magmas (Fujii et al., 1980), it has not been recognized as a magma chamber-scale process in silicic magmas. All major, trace, and REE modeling for the Fuji 1707 deposit show consistency with crystal fractionation as the dominant petrogenetic process. Although Kawamoto (1990, 1991a, 1991b, 1992) proposed that the observed trace element abundances and a decrease in $\mathrm{P}_{2} \mathrm{O}_{5}$ from andesite

to dacite cannot be explained by crystal fractionation, our study shows that both trace element variations and $\mathrm{P}_{2} \mathrm{O}_{5}$ abundances are consistent with crystal fractionation. The fact the crystal fractionation is a common process, and that it can easily explain the observed chemical gradients in the magma chamber, lead us to favor this model. We find that there is no need to resort to unusual processes such as liquid immiscibility to explain the 1707 chemically zoned magma chamber.

\section{Conclusions}

Major and trace element concentrations show substantial variations throughout the Fuji 1707 deposit. Decreasing abundances of $\mathrm{MgO}, \mathrm{CaO}, \mathrm{Al}_{2} \mathrm{O}_{3}$, and $\mathrm{P}_{2} \mathrm{O}_{5}$ with increasing $\mathrm{SiO}_{2}$ and non-linear trends on elemental variations are best explained by crystal fractionation of the observed phenocryst assemblage. Trace element models are consistent with the major element 
modeling. Chondrite-normalized REE abundances show expected enrichment from basalt to andesite and display strong negative $\mathrm{Eu}$ anomalies that increase from andesite to dacite, further supporting magma evolution by crystal fractionation. $\mathrm{Sr}, \mathrm{Nd}$, and $\mathrm{Pb}$ isotopic compositions show identical signatures throughout the deposit. Although these observations are all consistent with closed system crystal fractionation, a minor amount of crustal contamination is required by the radiogenic Os isotope signatures in the more evolved samples.

Our combined geochemical, isotopic, and petrographic observations suggest that the 1707 magma chamber evolved through three main stages including: 1) fractionation of parental magma; 2) formation of a chemically zoned magma chamber by crystal fractionation and minor crustal assimilation; and 3) basaltic intrusion into the magma chamber. Basalt intrusion during the final stage likely catalyzed the explosive eruption leading to progressive emptying of the dacitic and andesitic chamber magmas and the volumetrically substantial eruption of the youngest basaltic materials. 


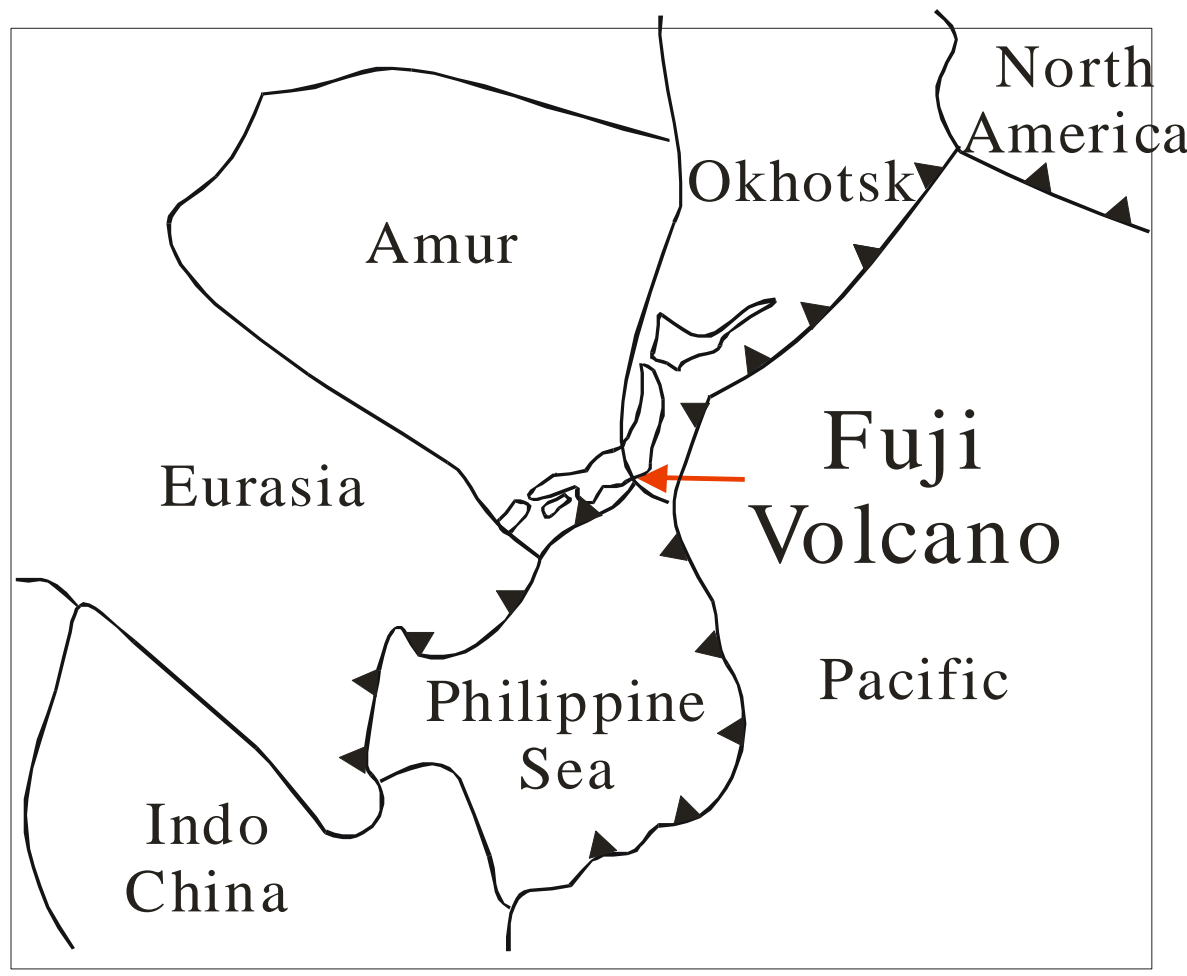

Fig. 1. Plate tectonic framework of Japan (modified after Taira, 2001). Fuji Volcano is located in south-central Honshu, lying over the westward-subducting Pacific Plate and possibly influenced by the Philippine Sea plate (Arculus et. al., 1991). 


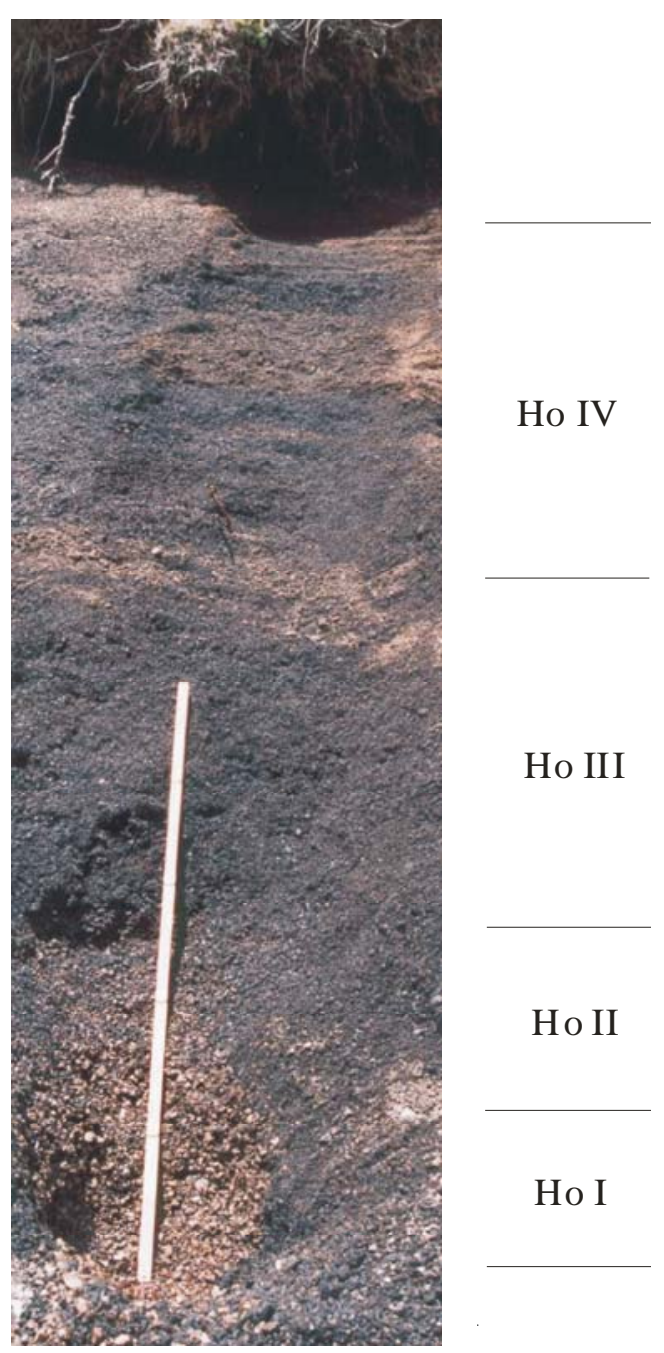

Fig. 2. A photograph of sampling site $\left(35^{\circ} 21^{\prime} 703^{\prime} \mathrm{N}, 138^{\circ} 47^{\prime} 035^{\prime \prime} \mathrm{E}\right)$. This sampling site displays a complete depositional section of the 1707 eruption. The total thickness of the deposit is $277 \mathrm{~cm}$. 


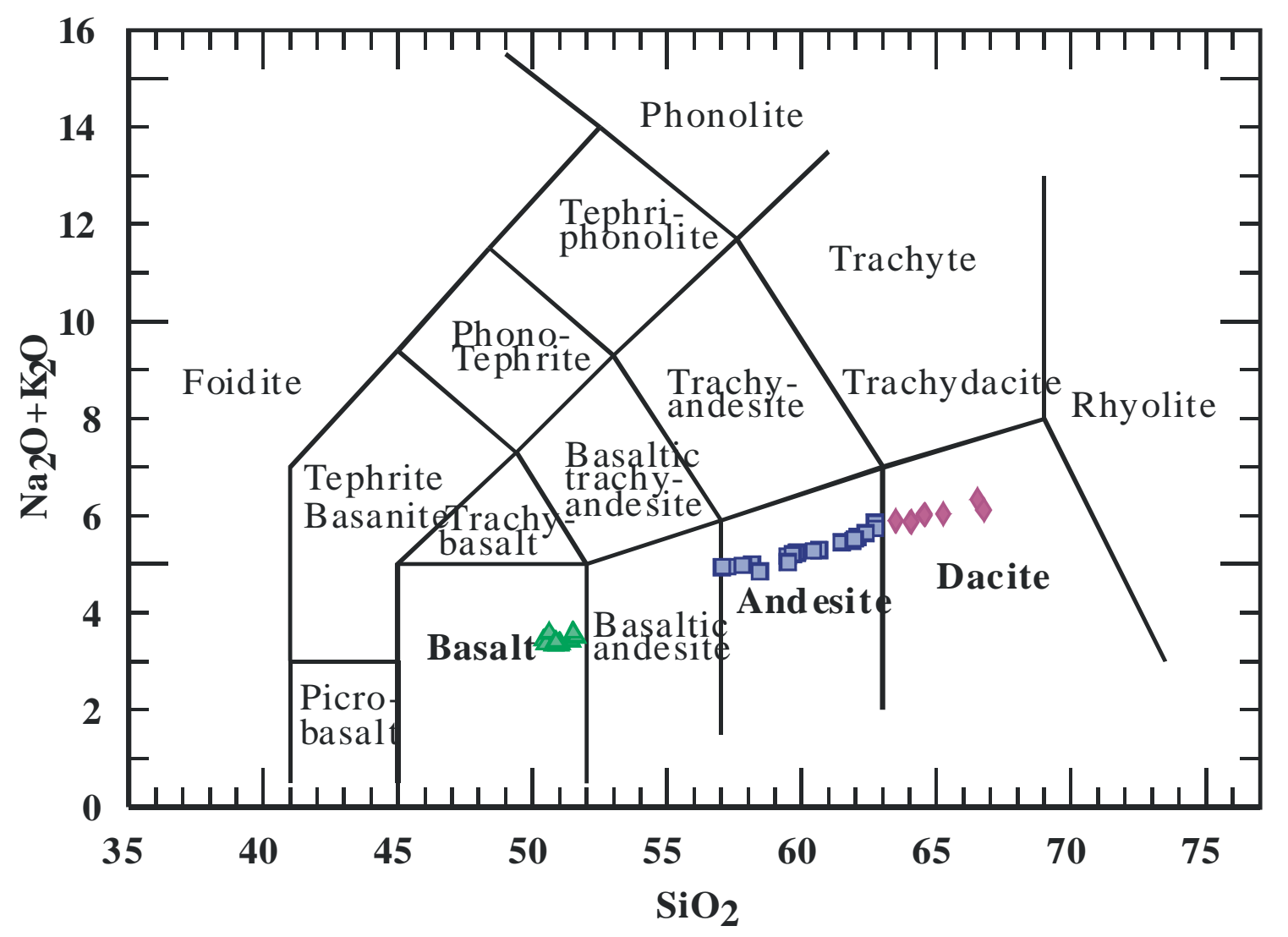

Fig. 3. Alkali versus silica clas sification diagram (after LeBas et al., 1986). The samples span a wide range of $\mathrm{SiO}_{2}$ from 50 to $67 \mathrm{wt} \%$ (basalt to dacite); however, there is a compositional gap between 52 to $57 \mathrm{wt} \% \mathrm{SiO}_{2}$. 


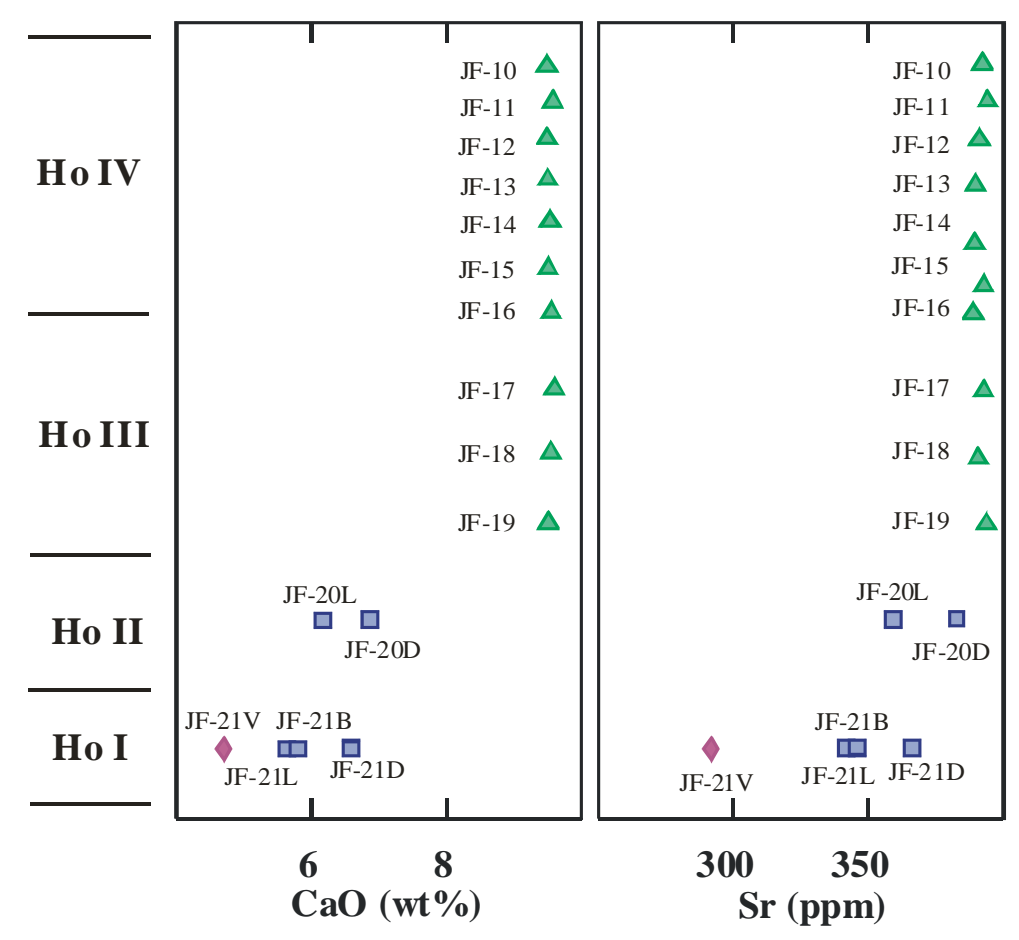

Fig. 4. Variation in $\mathrm{CaO}$ (wt \%) and Sr concentration (ppm) versus relative depth in the 1707 deposit at the second sampling site (fig. 2). JF-20 (Ho II) and JF-21 (Ho I) are heterogeneous with mixture of pumices and scorias. JF-20 was separated into light (JF-20L) and dark (JF-20D) fractions, while JF-21 was separated into very light (JF-21V), light (JF-21L), banded (JF-21B), and dark (JF-20D) fractions. The vertical axis is Miyaji's (1984) classification. 


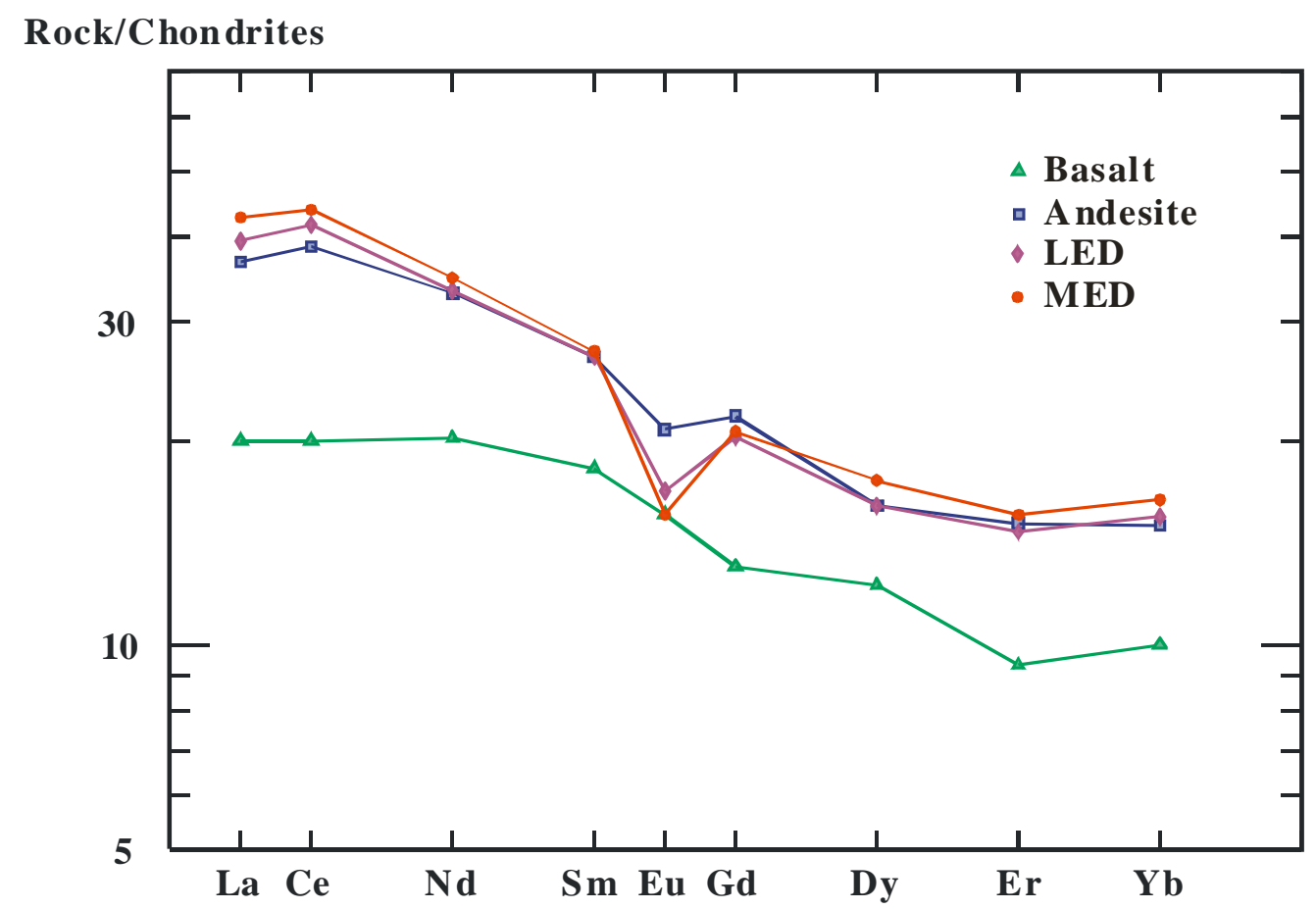

Fig. 5. Chondrite-normalized REE patterns for the Fuji 1707 deposit. The samples show relative enrichment fro $\mathrm{m}$ basalt to and esite. A slight increase in LREE and no increase in HREE from andesite to evolved dacite are observed. Chondrite abundances are from Nakamura (1974). (LED: least evolved dacite; MED: most evolved dacite) 


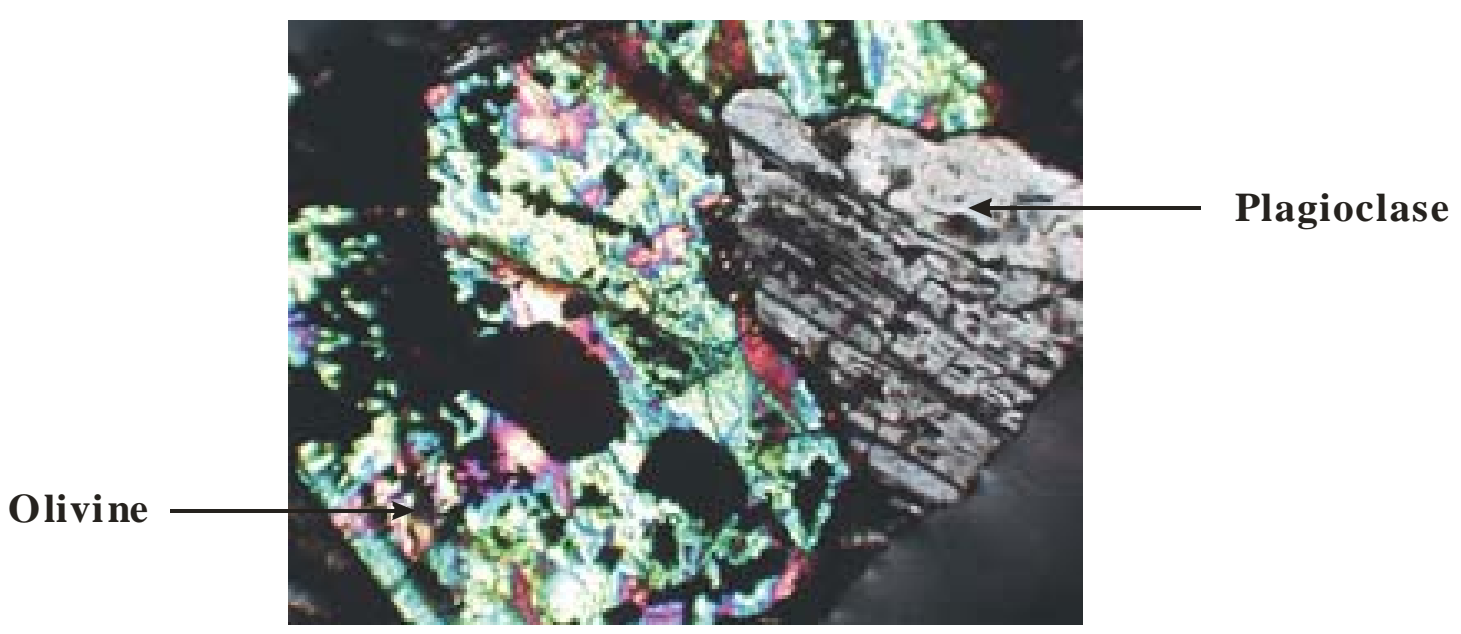

Fig. 6. Petrographic evidence of disequilibrium textures in plagioclase and olivine phenocrysts (10X magnification with crossed polarized light). 


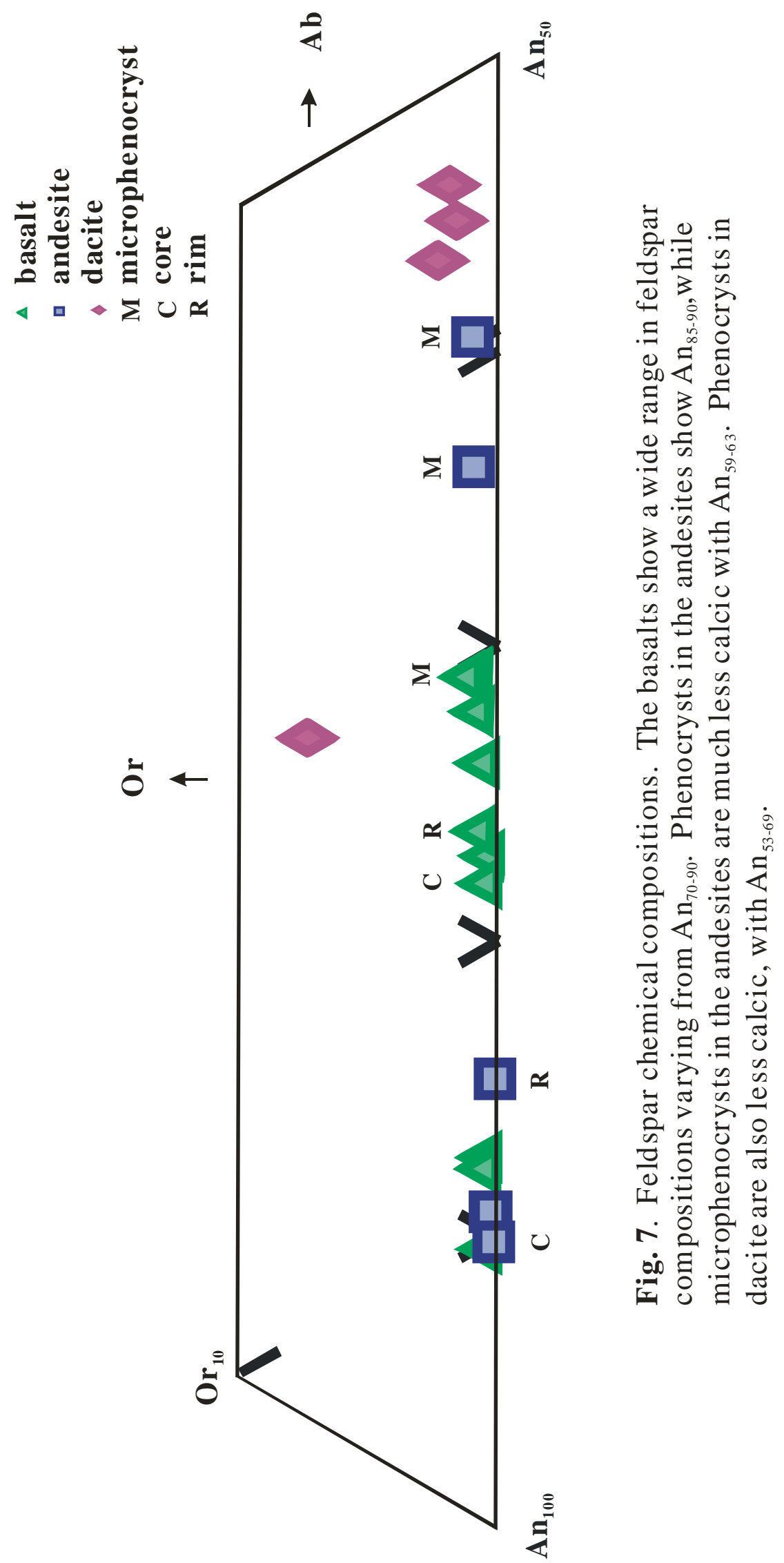




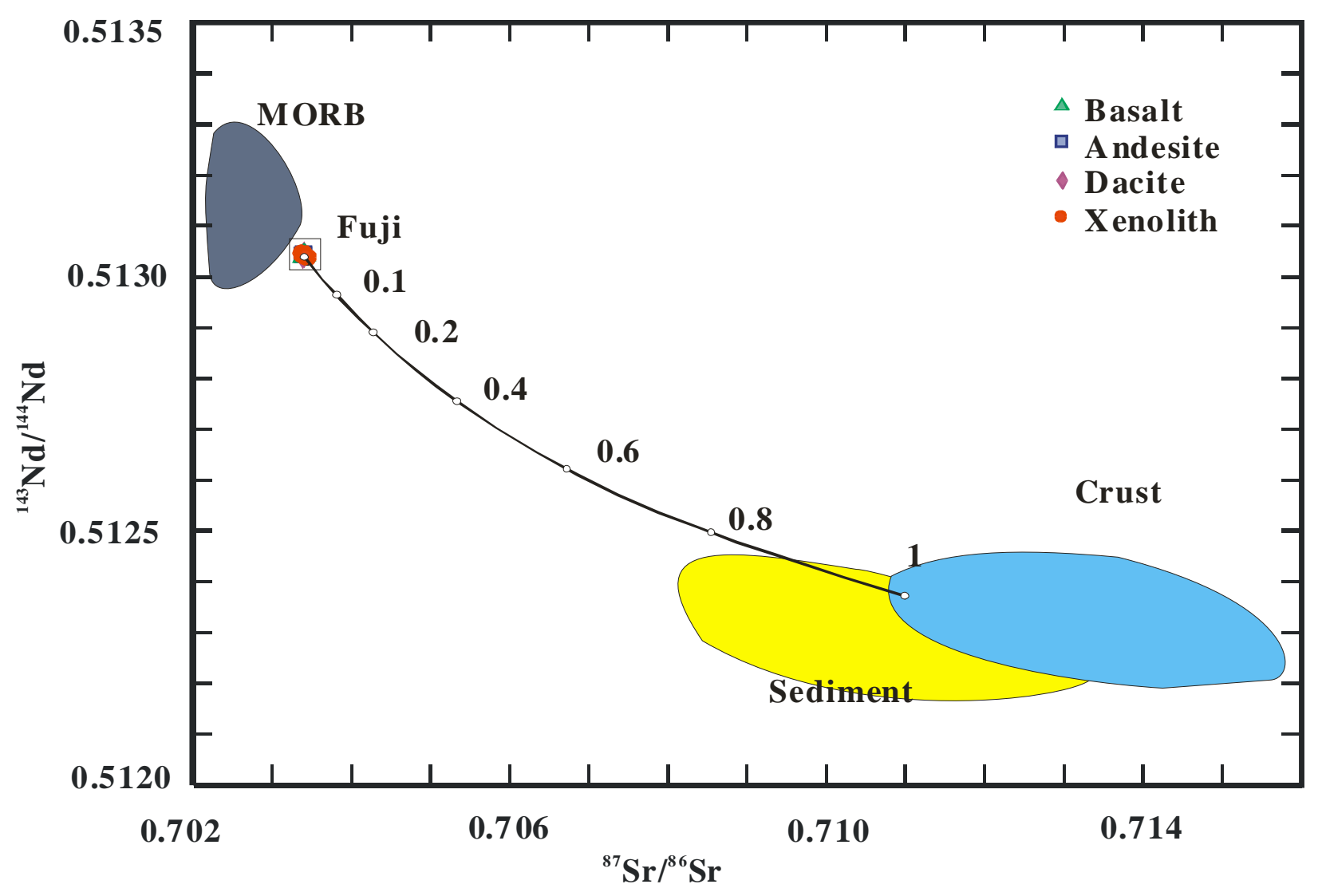

Fig. 8. $\mathrm{Sr}, \mathrm{Nd}$, and $\mathrm{Pb}$ is otopic compositions of repres entative juvenile and xenolith samples from the 1707 deposit. Also shown are fields for Pacific MORB (Ito et. al., 1987), Pacific sediments (BenOthman et. al., 1989), and Japanese upper crust (Geological Survey of Japan; Rezanov et al., 1999; Kondo et al., 2000). The square field $\left({ }^{43} \mathrm{Nd} /{ }^{144} \mathrm{Nd}\right.$ versus ${ }^{87} \mathrm{Sr} /{ }^{86} \mathrm{Sr}$ diagram $)$ includes all volcanic products from Fuji Volcano (Togashi, 1990). The mixing curve shown on the ${ }^{143} \mathrm{Nd} /{ }^{144} \mathrm{Nd}$ versus ${ }^{87} \mathrm{Sr} /{ }^{86} \mathrm{Sr}$ diagram represents bulk mixing between juvenile basalts and typical Japanese upper crust . Tick marks on mixing curve represent fraction of crust assimilated. 

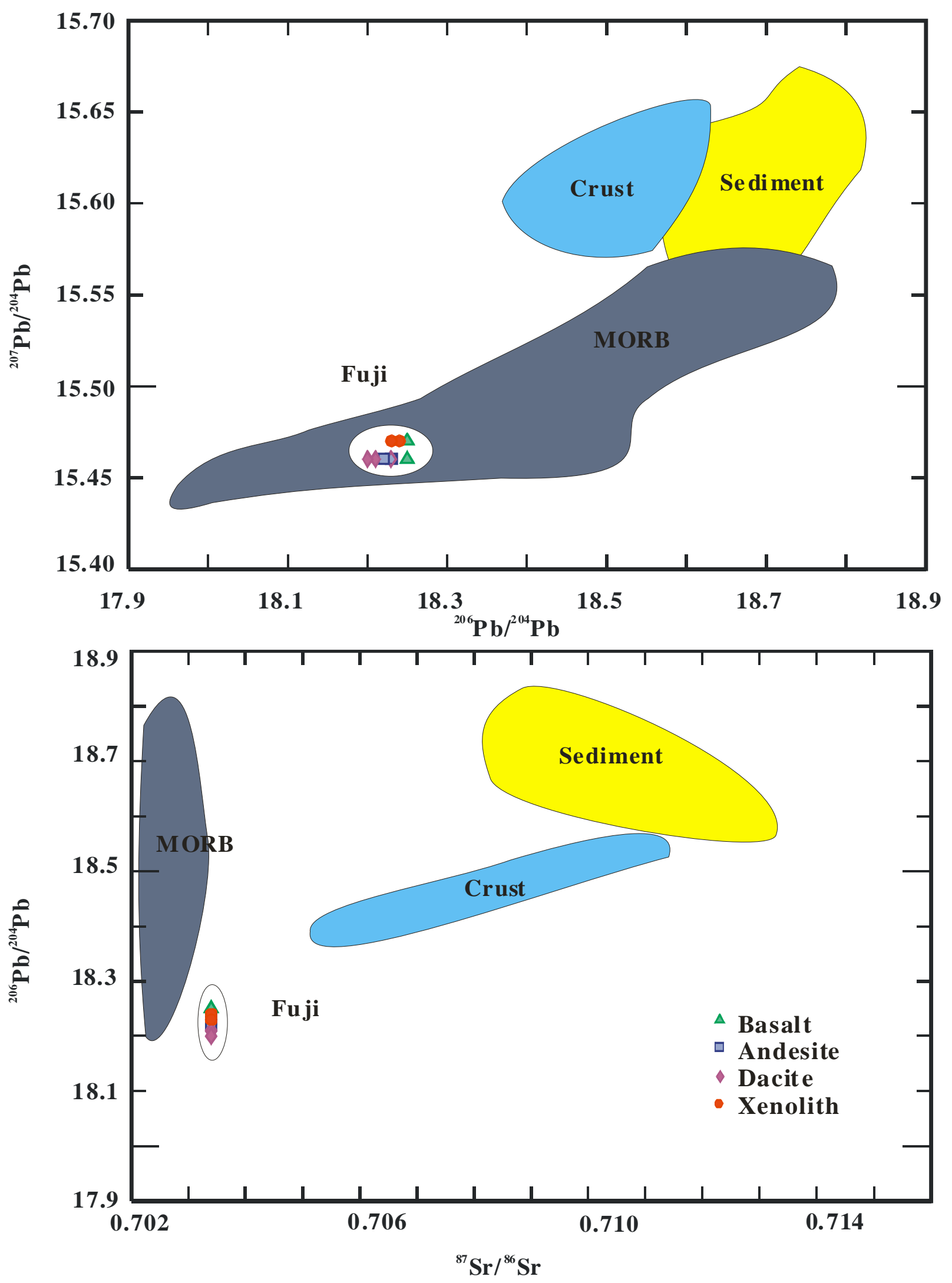

Fig. 8 (cont). 


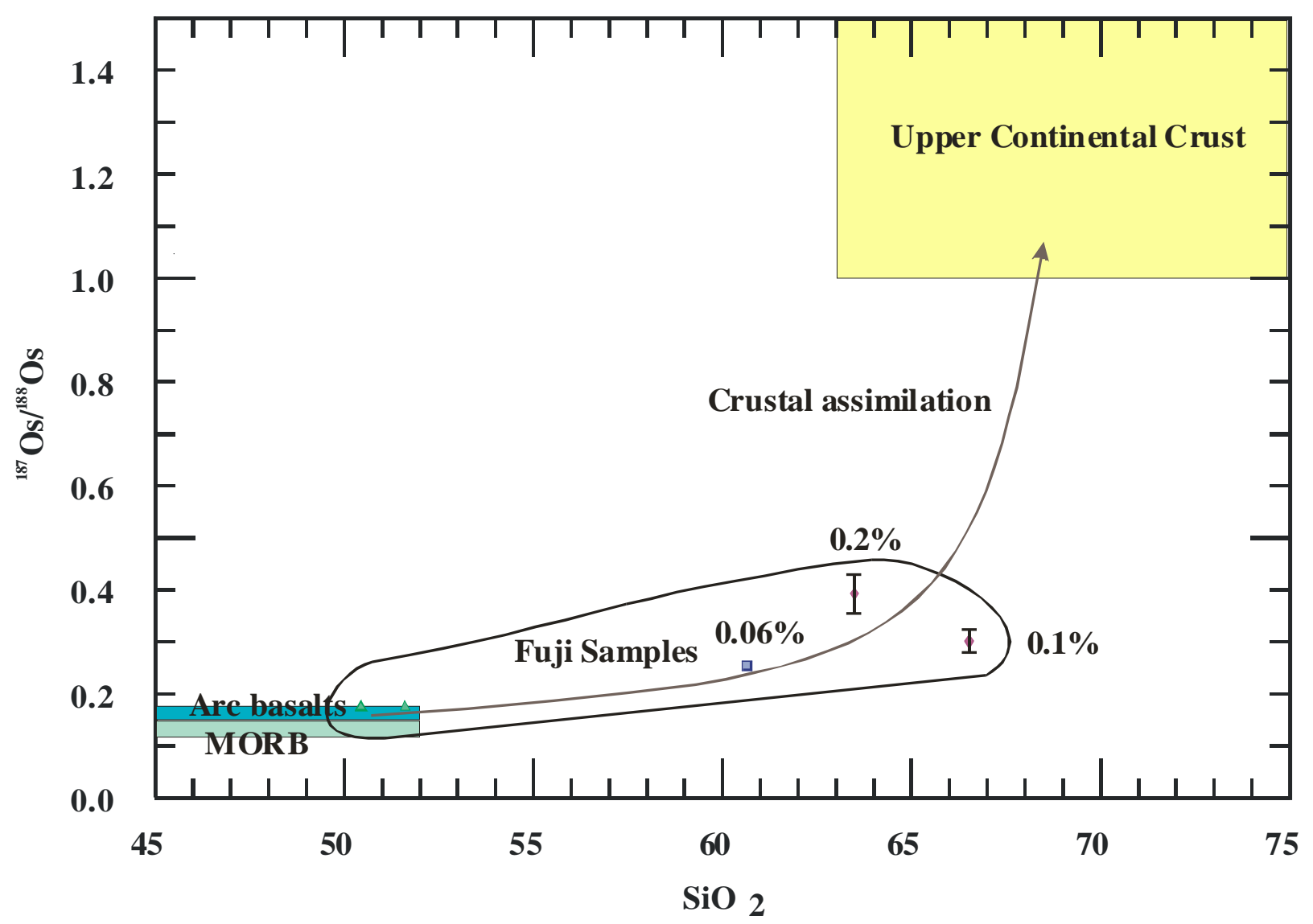

Fig. 9. Os isotopic compositions of representative samples from the Fuji 1707 deposit. Also shown are fields for MORB (Widom et al., 1997; Shirey and Walker, 1998), arc basalts (Widom et al., 2003a; Widom et al., 2003b), and upper crust (Peucker-Ehrenbrink and Jahn, 2001). The radiogenic signatures observed in the andesite and dacites can be explained by $\leq 0.2 \%$ of crustal assimilation. Labels on data points indicate percentage of crustal assimilation required to produce the observed radiogenic signatures assuming the uncontaminated magmas had $0.3 \mathrm{ppt}$ Os and ${ }^{187} \mathrm{Os} /{ }^{188} \mathrm{Os}=0.170$, and the crustal assimilant had 50 ppt Os and ${ }^{187}$ Os $/{ }^{188} \mathrm{Os}=1.06$, similar to estimates for average upper continental crust (Esser and Turekian, 1993; Peucker-Ehrenbrink and Jahn, 2001). 


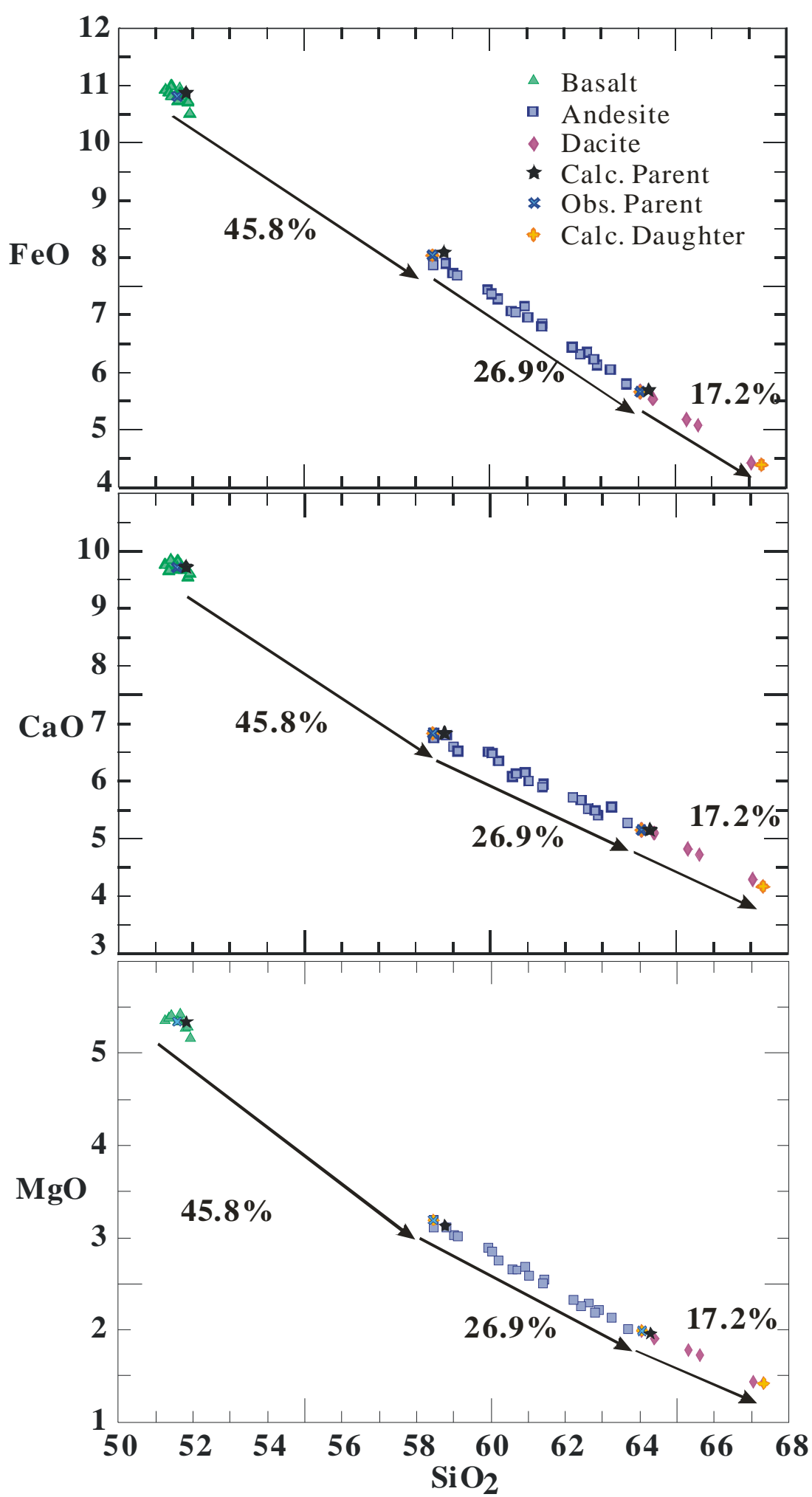

Fig. 10. Major element variation diagrams with modeling results. Arrows are schematic representations of modeled fractionation steps. The sum of squares of resid uals were $0.100,0.329$, and 0.073 for the res pective modeling steps. (Calc. Parent: Calculated parent; Obs. Parent: Observed parent; Calc. Daughter: Calculated daughter) 


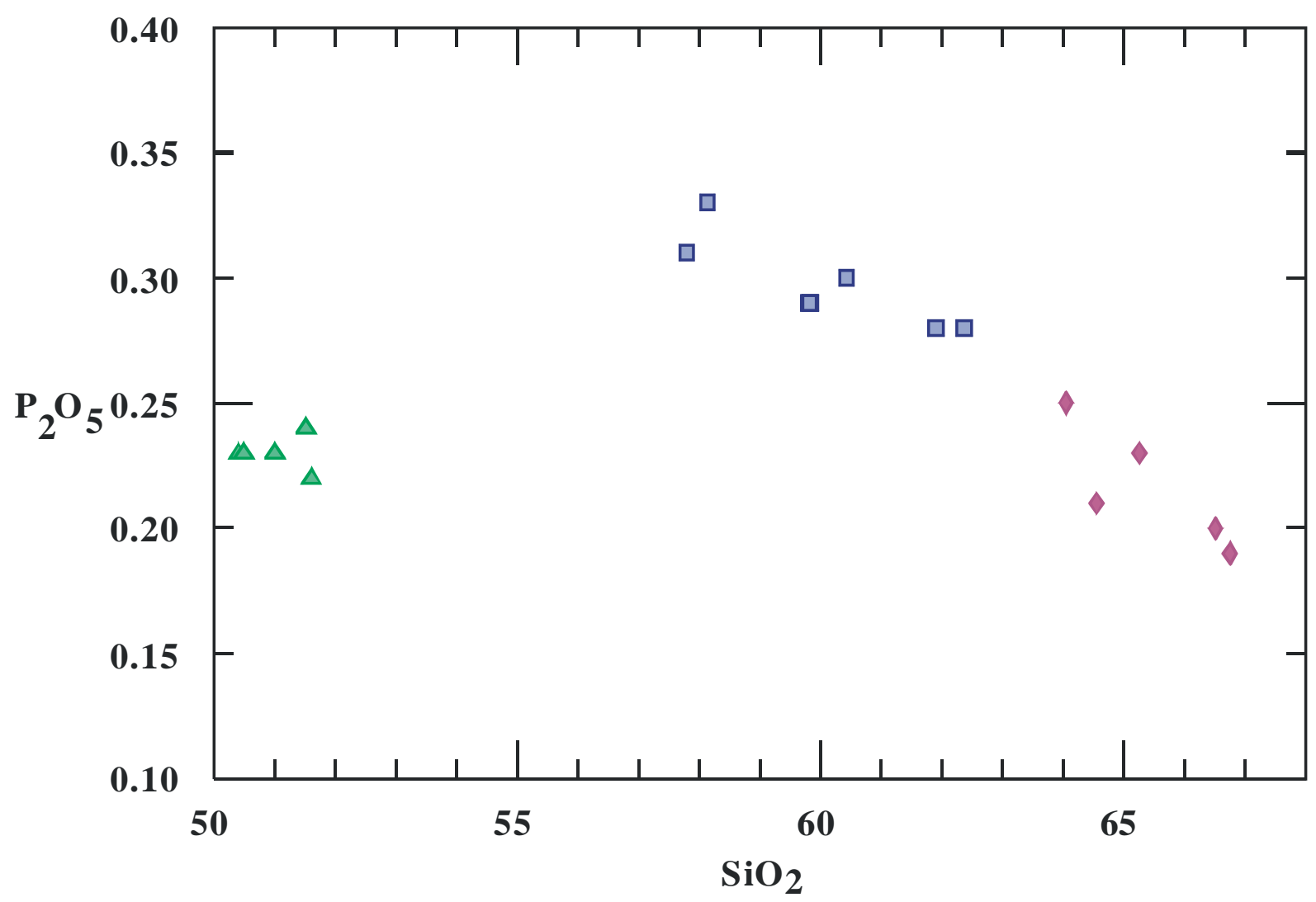

Fig. 11. $\mathrm{P}_{2} \mathrm{O}_{5}$ versus $\mathrm{SiO}_{2}$ for the Fuji 1707 deposit. $\mathrm{P}_{2} \mathrm{O}_{5}$ decreases with increasing $\mathrm{SiO}_{2}$ from andesite to dacite, consistent with apatite fractionation. The higher $\mathrm{P}_{2} \mathrm{O}_{5}$ contents of the andesites compared to the basalts indicate the absence of apatite fractionation during this stage. 


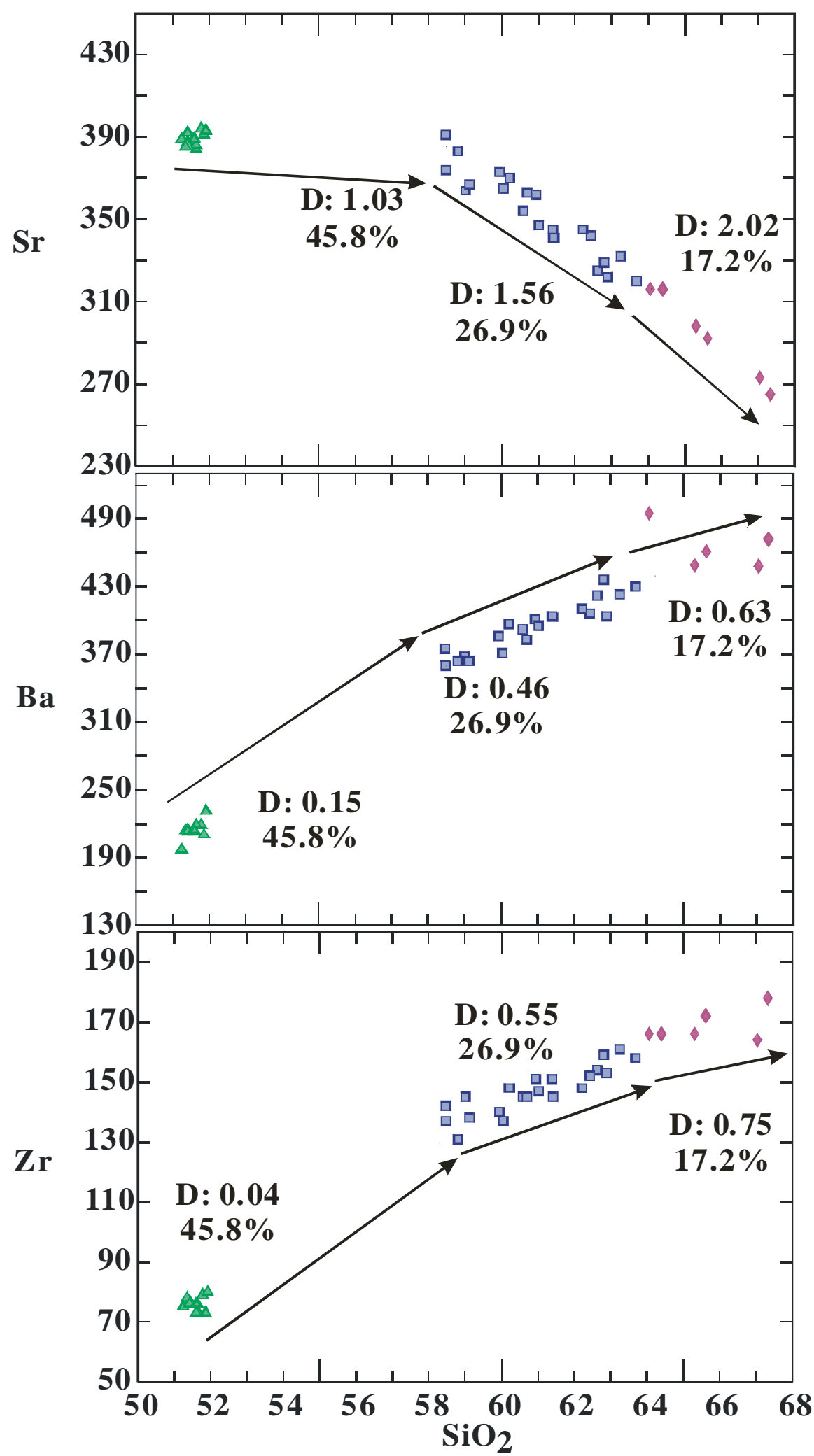

Fig. 12. Trace element variation diagrams with modeling results. Trace element modeling is consistent with major element modeling. Arrows are schematic representations of modeled fractionation steps. 

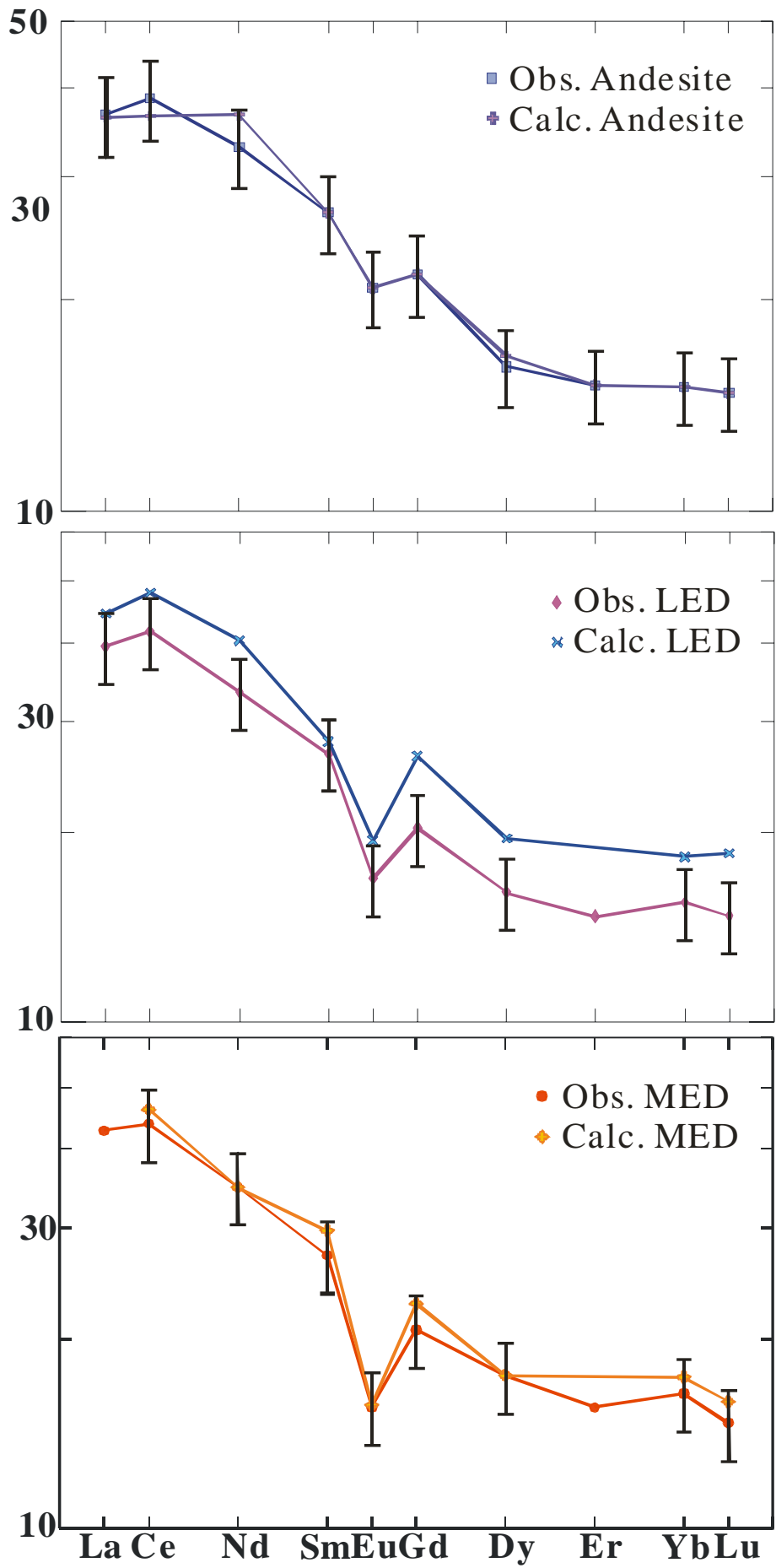

Fig. 13. Chondrite-normalized REE patterns with modeling results. The mineral assemblages and the relative proportions obtained from major element modeling were used for REE modeling. The error bars represent 13\% analytical errors based on estimated agreement of standards and linearity of regression lines. Chrondrite values are from Nakamura (1974). (Obs.: Observed; Calc: Calculated; LED: least evolved dacite; MED: most evolved dacite) 

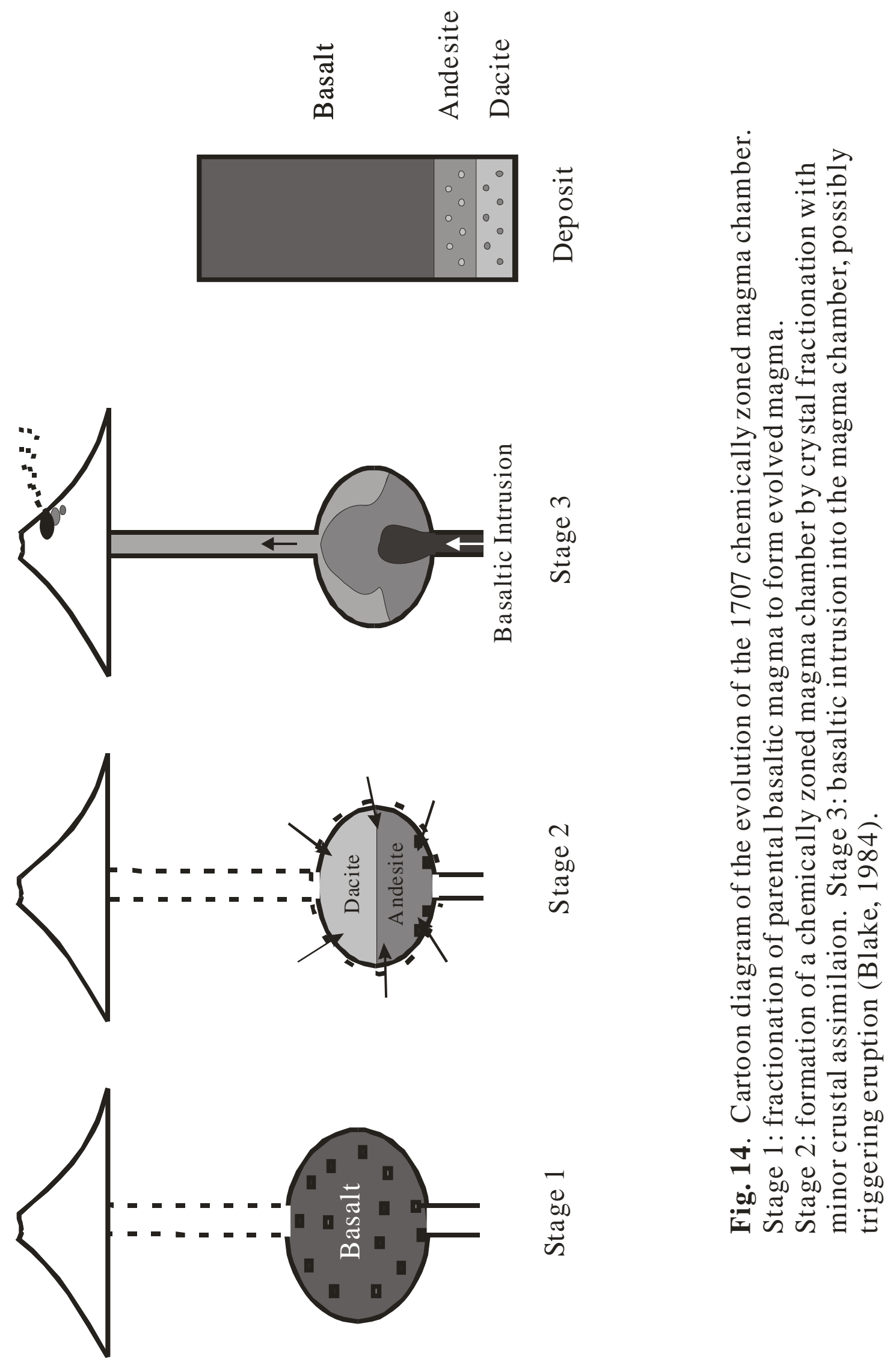
Table 1. Major and trace concentrations of juvenile and xenolith samples from the 1707 Fuji deposit. Major elements are in weight \%. Trace elements are in ppm.

Sampling site 1

\begin{tabular}{lrrrrrrrrr}
\hline Sample & JF-2a & JF-2b & JF-2c & JF-2d & JF-2e & JF-2f & JF-3a & JF-3b & JF-3c \\
units & Ho II & Ho II & Ho II & Ho II & Ho II & Ho II & Ho II & Ho II & Ho II \\
\hline $\mathbf{S i O}_{2}$ & 58.14 & 57.25 & 57.04 & 59.83 & 57.80 & 64.05 & 61.47 & 60.63 & 62.05 \\
$\mathbf{T i O}_{2}$ & 1.13 & 1.07 & 1.10 & 0.96 & 1.07 & 0.83 & 0.91 & 1.01 & 0.90 \\
$\mathbf{A l}_{2} \mathbf{O}_{3}$ & 16.80 & 16.29 & 16.57 & 15.93 & 16.49 & 15.92 & 15.87 & 16.34 & 16.05 \\
$\mathbf{F e}_{2} \mathbf{O}_{3}$ & 8.88 & 8.33 & 8.53 & 7.42 & 8.35 & 6.12 & 6.93 & 7.91 & 6.72 \\
$\mathbf{M n O}$ & 0.17 & 0.16 & 0.17 & 0.15 & 0.16 & 0.13 & 0.14 & 0.15 & 0.13 \\
$\mathbf{M g O}$ & 3.17 & 2.94 & 3.03 & 2.48 & 2.95 & 1.89 & 2.25 & 2.67 & 2.19 \\
$\mathbf{C a O}$ & 6.79 & 6.40 & 6.58 & 5.80 & 6.37 & 5.07 & 5.42 & 6.12 & 5.34 \\
$\mathbf{N a}_{2} \mathbf{O}$ & 3.61 & 3.55 & 3.58 & 3.64 & 3.56 & 3.77 & 3.65 & 3.64 & 3.68 \\
$\mathbf{K}_{2} \mathbf{O}$ & 1.39 & 1.40 & 1.36 & 1.60 & 1.41 & 2.10 & 1.80 & 1.65 & 1.88 \\
$\mathbf{P}_{2} \mathbf{O}_{5}$ & $0.33 *$ & 0.47 & 0.44 & $0.29 *$ & $0.31 *$ & $0.25 *$ & 0.41 & 0.16 & 0.39 \\
$\mathbf{L O I}$ & -0.03 & -0.08 & -0.12 & 0.05 & 0.02 & 0.23 & 0.02 & 0.00 & 0.23 \\
$\mathbf{T o t a l}$ & 100.39 & 97.79 & 98.27 & 98.13 & 98.50 & 100.35 & 98.86 & 100.29 & 99.56 \\
& & & & & & & & & \\
$\mathbf{N i}$ & 12 & 8 & 0 & 7 & 13 & 5 & 5 & 7 & 4 \\
$\mathbf{Z n}$ & 102 & 111 & 108 & 86 & 87 & 85 & 79 & 100 & 86 \\
$\mathbf{C u}$ & 69 & 68 & 74 & 69 & 71 & 57 & 65 & 70 & 61 \\
$\mathbf{C r}$ & 0 & 6 & 3 & 0 & 9 & 0 & 7 & 1 & 5 \\
$\mathbf{Z r}$ & 142 & 145 & 137 & 145 & 138 & 166 & 154 & 151 & 153 \\
$\mathbf{V}$ & 207 & 193 & 193 & 180 & 205 & 124 & 166 & 184 & 141 \\
$\mathbf{S c}$ & 23 & 24 & 24 & 19 & 23 & 15 & 19 & 21 & 18 \\
$\mathbf{B a}$ & 375 & 368 & 360 & 403 & 364 & 1594 & 422 & 401 & 404 \\
$\mathbf{S r}$ & 391 & 364 & 374 & 341 & 367 & 316 & 325 & 362 & 322 \\
$\mathbf{R b}$ & 34 & 21 & 24 & 47 & 46 & 53 & 38 & 24 & 35 \\
$\mathbf{Y}$ & 35 & 34 & 33 & 32 & 33 & 32 & 34 & 34 & 33 \\
\hline
\end{tabular}

*Measured using standard addition method. 
Table 1 (cont).

Sampling site 1

\begin{tabular}{|c|c|c|c|c|c|c|c|c|c|}
\hline & $\begin{array}{c}\text { JF-3d } \\
\text { Ho II }\end{array}$ & $\begin{array}{l}\text { JF-3e } \\
\text { Ho II }\end{array}$ & $\begin{array}{l}\text { JF-3f } \\
\text { Ho II }\end{array}$ & $\begin{array}{l}\text { JF-4a } \\
\text { Ho II }\end{array}$ & $\begin{array}{l}\text { JF-4b } \\
\text { Ho II }\end{array}$ & $\begin{array}{l}\text { JF-4d } \\
\text { Ho II }\end{array}$ & $\begin{array}{l}\text { JF-4e } \\
\text { Ho II }\end{array}$ & $\begin{array}{l}\text { JF-4f } \\
\text { Ho II }\end{array}$ & $\begin{array}{r}\text { JF-5a } \\
\text { Ho I }\end{array}$ \\
\hline $\mathrm{SiO}_{2}$ & 59.84 & 59.82 & 63.48 & 59.47 & 59.67 & 60.62 & 64.55 & 62.71 & 62.73 \\
\hline $\mathrm{TiO}_{2}$ & 1.03 & 0.99 & 0.82 & 1.03 & 1.01 & 0.98 & 0.77 & 0.83 & 0.88 \\
\hline $\mathrm{Al}_{2} \mathbf{O}_{3}$ & 16.37 & 16.19 & 15.79 & 16.40 & 16.42 & 16.17 & 15.46 & 15.76 & 15.77 \\
\hline $\mathrm{Fe}_{2} \mathrm{O}_{3}$ & 8.04 & 7.58 & 6.23 & 8.20 & 7.74 & 7.46 & 5.69 & 6.35 & 6.67 \\
\hline MnO & 0.16 & 0.15 & 0.13 & 0.16 & 0.15 & 0.14 & 0.12 & 0.13 & 0.14 \\
\hline MgO & 2.73 & 2.54 & 1.97 & 2.87 & 2.62 & 2.48 & 1.76 & 1.98 & 2.11 \\
\hline $\mathrm{CaO}$ & 6.31 & 5.88 & 5.10 & 6.46 & 5.99 & 5.82 & 4.76 & 5.19 & 5.50 \\
\hline $\mathrm{Na}_{2} \mathrm{O}$ & 3.66 & 3.64 & 3.75 & 3.66 & 3.64 & 3.66 & 3.75 & 3.80 & 3.79 \\
\hline $\mathbf{K}_{2} \mathbf{O}$ & 1.59 & 1.59 & 2.14 & 1.51 & 1.57 & 1.64 & 2.27 & 2.06 & 1.94 \\
\hline $\mathbf{P}_{2} \mathbf{O}_{5}$ & $0.29 *$ & $0.29 *$ & 0.31 & 0.28 & 0.44 & 0.50 & $0.21 *$ & 0.29 & 0.32 \\
\hline LOI & -0.11 & -0.03 & 0.23 & -0.01 & 0.05 & 0.01 & 0.53 & 0.34 & -0.06 \\
\hline Total & 99.90 & 98.63 & 99.95 & 100.03 & 99.31 & 99.47 & 99.88 & 99.44 & 99.77 \\
\hline $\mathbf{N i}$ & 7 & 1 & 11 & 14 & 5 & 3 & 3 & 6 & 4 \\
\hline Zn & 89 & 88 & 83 & 101 & 95 & 85 & 66 & 67 & 76 \\
\hline $\mathbf{C u}$ & 71 & 74 & 54 & 76 & 74 & 74 & 51 & 60 & 61 \\
\hline $\mathrm{Cr}$ & 0 & 2 & 0 & 2 & 2 & 1 & 1 & 0 & 2 \\
\hline $\mathrm{Zr}$ & 148 & 147 & 166 & 140 & 145 & 151 & 166 & 158 & 161 \\
\hline $\mathbf{V}$ & 185 & 184 & 136 & 185 & 183 & 169 & 139 & 132 & 157 \\
\hline Sc & 21 & 21 & 16 & 22 & 23 & 22 & 13 & 16 & 16 \\
\hline Ba & 397 & 395 & 495 & 386 & 392 & 404 & 449 & 430 & 423 \\
\hline Sr & 370 & 347 & 316 & 373 & 354 & 345 & 298 & 320 & 332 \\
\hline $\mathbf{R b}$ & 40 & 32 & 43 & 24 & 41 & 45 & 50 & 35 & 52 \\
\hline $\mathbf{Y}$ & 33 & 33 & 34 & 34 & 33 & 35 & 33 & 33 & 32 \\
\hline
\end{tabular}


Table 1 (cont).

Sampling site 1

\begin{tabular}{lrrr}
\hline & $\begin{array}{r}\text { JF-5b } \\
\text { Ho I }\end{array}$ & $\begin{array}{r}\text { JF-5c } \\
\text { Ho I }\end{array}$ & $\begin{array}{r}\text { JF-5d } \\
\text { Ho I }\end{array}$ \\
\hline $\mathbf{S i O}_{2}$ & 61.90 & 66.51 & 66.75 \\
$\mathbf{T i O}_{2}$ & 0.92 & 0.68 & 0.69 \\
$\mathbf{A l}_{2} \mathbf{O}_{3}$ & 16.04 & 15.14 & 15.26 \\
$\mathbf{F e}_{\mathbf{2}} \mathbf{O}_{3}$ & 6.82 & 4.87 & 4.84 \\
$\mathbf{M n O}$ & 0.13 & 0.11 & 0.10 \\
$\mathbf{M g O}$ & 2.16 & 1.43 & 1.41 \\
$\mathbf{C a O}$ & 5.41 & 4.26 & 4.13 \\
$\mathbf{N a}_{2} \mathbf{O}$ & 3.70 & 3.81 & 3.71 \\
$\mathbf{K}_{\mathbf{2}} \mathbf{O}$ & 1.78 & 2.52 & 2.41 \\
$\mathbf{P}_{2} \mathbf{O}_{5}$ & $0.28 *$ & 0.20 & $0.19 *$ \\
$\mathbf{L O I}$ & -0.01 & 0.31 & 0.35 \\
$\mathbf{T o t a l}$ & 99.13 & 99.83 & 99.85 \\
& & & \\
$\mathbf{N i}$ & 1 & 5 & 0 \\
$\mathbf{Z n}$ & 96 & 63 & 60 \\
$\mathbf{C u}$ & 75 & 42 & 52 \\
$\mathbf{C r}$ & 5 & 3 & 8 \\
$\mathbf{Z r}$ & 159 & 164 & 178 \\
$\mathbf{V}$ & 158 & 101 & 101 \\
$\mathbf{S c}$ & 21 & 11 & 16 \\
$\mathbf{B a}$ & 436 & 448 & 472 \\
$\mathbf{S r}$ & 329 & 273 & 265 \\
$\mathbf{R b}$ & 28 & 43 & 45 \\
$\mathbf{Y}$ & 35 & 29 & 36 \\
\hline
\end{tabular}


Table 1 (cont).

Sampling site 2

\begin{tabular}{lrrrrrrrrr}
\hline & JF-10 & JF-11 & JF-12 & JF-13 & JF-14 & JF-15 & JF-16 & JF-17 & JF-18 \\
& Ho IV & Ho IV & Ho IV & Ho IV & Ho IV & Ho IV & Ho IV & Ho III & Ho III \\
\hline $\mathbf{S i O}_{2}$ & 50.41 & 51.43 & 50.50 & 50.78 & 50.61 & 51.61 & 50.96 & 51.01 & 50.87 \\
$\mathbf{T i O}_{2}$ & 1.35 & 1.36 & 1.35 & 1.34 & 1.33 & 1.34 & 1.33 & 1.34 & 1.33 \\
$\mathbf{A l}_{2} \mathbf{O}_{3}$ & 17.06 & 17.11 & 16.80 & 16.76 & 17.14 & 17.10 & 16.89 & 17.14 & 16.93 \\
$\mathbf{F e}_{2} \mathbf{O}_{3}$ & 11.92 & 11.87 & 11.98 & 11.96 & 11.90 & 11.84 & 11.91 & 11.91 & 11.76 \\
$\mathbf{M n O}$ & 0.19 & 0.19 & 0.19 & 0.19 & 0.19 & 0.19 & 0.19 & 0.19 & 0.19 \\
$\mathbf{M g O}$ & 5.26 & 5.23 & 5.30 & 5.28 & 5.30 & 5.26 & 5.36 & 5.37 & 5.26 \\
$\mathbf{C a O}$ & 9.59 & 9.60 & 9.59 & 9.51 & 9.51 & 9.49 & 9.63 & 9.76 & 9.67 \\
$\mathbf{N a}_{2} \mathbf{O}$ & 2.70 & 2.68 & 2.63 & 2.62 & 2.65 & 2.83 & 2.61 & 2.65 & 2.67 \\
$\mathbf{K}_{\mathbf{2}} \mathbf{O}$ & 0.73 & 0.74 & 0.73 & 0.72 & 0.93 & 0.67 & 0.72 & 0.72 & 0.73 \\
$\mathbf{P}_{2} \mathbf{O}_{5}$ & $0.23 *$ & 0.29 & $0.23 *$ & 0.35 & 0.17 & $0.22 *$ & 0.24 & $0.23 *$ & 0.36 \\
$\mathbf{L O I}$ & -0.21 & -0.27 & -0.18 & -0.24 & -0.26 & -0.23 & -0.23 & -0.20 & -0.29 \\
$\mathbf{T o t a l}$ & 99.22 & 100.24 & 99.10 & 99.27 & 99.46 & 100.33 & 99.62 & 100.12 & 99.49 \\
& & & & & & & & & \\
$\mathbf{N i}$ & 26 & 24 & 32 & 24 & 29 & 22 & 26 & 19 & 21 \\
$\mathbf{Z n}$ & 101 & 110 & 100 & 105 & 112 & 93 & 89 & 104 & 108 \\
$\mathbf{C u}$ & 164 & 169 & 179 & 175 & 176 & 168 & 174 & 178 & 171 \\
$\mathbf{C r}$ & 40 & 39 & 39 & 41 & 48 & 43 & 43 & 42 & 42 \\
$\mathbf{Z r}$ & 75 & 79 & 77 & 76 & 78 & 73 & 73 & 76 & 73 \\
$\mathbf{V}$ & 395 & 403 & 429 & 399 & 426 & 406 & 396 & 375 & 423 \\
$\mathbf{S c}$ & 36 & 38 & 39 & 38 & 40 & 37 & 36 & 36 & 39 \\
$\mathbf{B a}$ & 197 & 219 & 213 & 218 & 214 & 210 & 219 & 214 & 213 \\
$\mathbf{S r}$ & 389 & 394 & 387 & 384 & 385 & 391 & 386 & 392 & 389 \\
$\mathbf{R b}$ & 8 & 22 & 0 & 28 & 0 & 2 & 7 & 0 & 19 \\
$\mathbf{Y}$ & 23 & 26 & 26 & 26 & 26 & 24 & 25 & 24 & 24 \\
\hline$*$ Measured using standard addition method. & & & & &
\end{tabular}


Table 1 (cont).

Sampling site 2

\begin{tabular}{|c|c|c|c|c|c|c|c|}
\hline & $\begin{array}{r}\text { JF-19 } \\
\text { Ho III }\end{array}$ & $\begin{array}{r}\text { JF-20L } \\
\text { Ho II }\end{array}$ & $\begin{array}{r}\text { JF-20D } \\
\text { Ho II }\end{array}$ & $\begin{array}{r}\text { JF-21V } \\
\text { Ho I }\end{array}$ & $\begin{array}{r}\text { JF-21L } \\
\text { Ho I }\end{array}$ & $\begin{array}{r}\text { F-21D } \\
\text { Ho I }\end{array}$ & $\begin{array}{r}\text { JF-21B } \\
\text { Ho I } \\
\end{array}$ \\
\hline $\mathrm{SiO}_{2}$ & 51.52 & 60.43 & 58.43 & 65.26 & 62.37 & 59.48 & 61.96 \\
\hline $\mathrm{TiO}_{2}$ & 1.33 & 1.03 & 1.12 & 0.75 & 0.94 & 1.04 & 0.95 \\
\hline $\mathbf{A l}_{2} \mathbf{O}_{3}$ & 17.16 & 16.47 & 16.61 & 15.47 & 16.21 & 16.41 & 16.20 \\
\hline $\mathrm{Fe}_{2} \mathrm{O}_{3}$ & 11.59 & 7.80 & 8.72 & 5.61 & 7.02 & 8.11 & 7.13 \\
\hline MnO & 0.19 & 0.15 & 0.17 & 0.12 & 0.14 & 0.16 & 0.14 \\
\hline MgO & 5.12 & 2.64 & 3.09 & 1.71 & 2.26 & 2.82 & 2.31 \\
\hline $\mathrm{CaO}$ & 9.54 & 6.10 & 6.76 & 4.69 & 5.66 & 6.42 & 5.70 \\
\hline $\mathrm{Na}_{2} \mathrm{O}$ & 2.79 & 3.67 & 3.55 & 3.75 & 3.87 & 3.60 & 3.74 \\
\hline $\mathbf{K}_{2} \mathbf{O}$ & 0.80 & 1.61 & 1.30 & 2.29 & 1.77 & 1.44 & 1.78 \\
\hline $\mathbf{P}_{2} \mathbf{O}_{5}$ & $0.24 *$ & $0.30 *$ & 0.48 & $0.23 *$ & $0.28 *$ & 0.39 & 0.39 \\
\hline LOI & -0.22 & 0.15 & -0.03 & 0.39 & 0.10 & -0.01 & 0.13 \\
\hline Total & 100.05 & 100.37 & 100.20 & 100.28 & 100.06 & 99.85 & 100.43 \\
\hline $\mathbf{N i}$ & 19 & 9 & 12 & 4 & 5 & 10 & 5 \\
\hline Zn & 86 & 92 & 99 & 71 & 95 & 90 & 105 \\
\hline $\mathrm{Cu}$ & 161 & 75 & 81 & 54 & 69 & 79 & 66 \\
\hline $\mathrm{Cr}$ & 38 & 5 & 8 & 0 & 0 & 1 & 0 \\
\hline Zr & 80 & 145 & 131 & 172 & 152 & 137 & 148 \\
\hline $\mathbf{V}$ & 371 & 176 & 198 & 109 & 143 & 186 & 155 \\
\hline Sc & 36 & 21 & 24 & 14 & 19 & 22 & 18 \\
\hline Ba & 231 & 383 & 364 & 461 & 406 & 371 & 410 \\
\hline Sr & 393 & 363 & 383 & 292 & 342 & 365 & 345 \\
\hline Rb & 11 & 51 & 37 & 45 & 51 & 28 & 34 \\
\hline $\mathbf{Y}$ & 26 & 31 & 31 & 34 & 33 & 31 & 33 \\
\hline
\end{tabular}


Table 1 (cont).

Xenoliths: basalt

\begin{tabular}{lrrrrrrr}
\hline & JF-6a & JF-6b & JF-6c & JF-6d & JF-7a & JF-8a & JF-9b \\
\hline $\mathbf{S i O}_{2}$ & 49.68 & 51.42 & 51.10 & 51.15 & 50.49 & 50.08 & 50.92 \\
$\mathbf{T i O}_{2}$ & 1.37 & 0.98 & 1.37 & 0.96 & 1.31 & 1.34 & 0.92 \\
$\mathbf{A l}_{2} \mathbf{O}_{3}$ & 16.89 & 18.65 & 17.14 & 18.43 & 17.04 & 16.92 & 17.72 \\
$\mathbf{F e}_{\mathbf{2}} \mathbf{O}_{3}$ & 12.60 & 10.18 & 12.16 & 10.67 & 11.80 & 12.25 & 10.52 \\
$\mathbf{M n O}_{\mathbf{M g O}}$ & 0.19 & 0.15 & 0.19 & 0.17 & 0.18 & 0.19 & 0.17 \\
$\mathbf{C a O}$ & 5.94 & 5.51 & 5.06 & 5.43 & 6.33 & 6.14 & 6.10 \\
$\mathbf{N a} \mathbf{O}$ & 9.87 & 9.37 & 9.40 & 9.60 & 9.80 & 9.99 & 10.28 \\
$\mathbf{K} \mathbf{O}$ & 2.37 & 2.85 & 2.91 & 2.80 & 2.51 & 2.40 & 2.56 \\
$\mathbf{P}_{\mathbf{2}} \mathbf{O}_{5}$ & 0.60 & 0.51 & 0.68 & 0.47 & 0.59 & 0.54 & 0.37 \\
$\mathbf{L O I}$ & 0.26 & 0.24 & 0.31 & 0.12 & 0.28 & 0.24 & 0.29 \\
$\mathbf{T o t a l}$ & 9.39 & -0.28 & -0.30 & -0.30 & -0.29 & -0.28 & -0.11 \\
& & 99.39 & 100.02 & 99.50 & 100.05 & 99.79 & 99.73 \\
$\mathbf{N i}$ & 49 & 48 & 26 & 25 & 57 & 36 & 38 \\
$\mathbf{Z n}$ & 102 & 82 & 119 & 90 & 98 & 107 & 95 \\
$\mathbf{C u}$ & 199 & 114 & 147 & 84 & 170 & 196 & 94 \\
$\mathbf{C r}$ & 57 & 55 & 30 & 31 & 110 & 99 & 81 \\
$\mathbf{Z r}$ & 71 & 48 & 71 & 39 & 76 & 71 & 41 \\
$\mathbf{V}$ & 409 & 314 & 385 & 367 & 386 & 399 & 336 \\
$\mathbf{S c}$ & 38 & 32 & 32 & 31 & 41 & 43 & 35 \\
$\mathbf{B a}$ & 205 & 160 & 208 & 150 & 196 & 202 & 133 \\
$\mathbf{S r}$ & 363 & 397 & 410 & 396 & 363 & 354 & 359 \\
$\mathbf{R b}$ & 5 & 17 & 13 & 10 & 11 & 18 & 5 \\
$\mathbf{Y}$ & 25 & 18 & 26 & 18 & 27 & 27 & 17 \\
\hline
\end{tabular}


Table 1 (cont).

Xenoliths: gabbro

\begin{tabular}{lrrrrr}
\hline & JF-1 & JF-4c & JF-7b & JF-8b & JF-9a \\
\hline $\mathbf{S i O}_{2}$ & 48.40 & 44.90 & 46.68 & 46.80 & 46.94 \\
$\mathbf{T i O}_{2}$ & 1.11 & 0.19 & 0.23 & 1.14 & 0.57 \\
$\mathbf{A l}_{2} \mathbf{O}_{3}$ & 16.35 & 23.19 & 23.17 & 18.97 & 25.92 \\
$\mathbf{F e}_{2} \mathbf{O}_{3}$ & 12.14 & 7.67 & 6.24 & 12.70 & 5.65 \\
$\mathbf{M n O}$ & 0.18 & 0.12 & 0.10 & 0.16 & 0.08 \\
$\mathbf{M g O}$ & 7.81 & 8.82 & 7.60 & 7.69 & 2.81 \\
$\mathbf{C a O}$ & 10.23 & 13.29 & 14.74 & 11.44 & 14.64 \\
$\mathbf{N a}_{\mathbf{2}} \mathbf{O}$ & 2.22 & 1.00 & 0.95 & 1.75 & 1.77 \\
$\mathbf{K}_{2} \mathbf{O}$ & 0.13 & 0.05 & 0.03 & 0.18 & 0.09 \\
$\mathbf{P}_{\mathbf{2}} \mathbf{O}_{\mathbf{5}}$ & 0.21 & 0.12 & 0.10 & 0.13 & 0.12 \\
$\mathbf{L O I}$ & -0.34 & -0.27 & -0.12 & -0.35 & -0.07 \\
$\mathbf{T o t a l}$ & 98.45 & 99.08 & 99.72 & 100.61 & 98.51 \\
& & & & & \\
$\mathbf{N i}$ & 64 & 83 & 77 & 64 & 13 \\
$\mathbf{Z n}$ & 102 & 133 & 36 & 89 & 45 \\
$\mathbf{C u}$ & 40 & 15 & 12 & 64 & 53 \\
$\mathbf{C r}$ & 110 & 153 & 276 & 137 & 84 \\
$\mathbf{Z r}$ & 13 & 6 & 8 & 22 & 5 \\
$\mathbf{V}$ & 461 & 64 & 100 & 459 & 220 \\
$\mathbf{S c}$ & 41 & 19 & 28 & 36 & 17 \\
$\mathbf{B a}$ & 81 & 37 & 39 & 81 & 73 \\
$\mathbf{S r}$ & 382 & 463 & 452 & 419 & 590 \\
$\mathbf{R b}$ & 0 & 3 & 14 & 35 & 7 \\
$\mathbf{Y}$ & 14 & 6 & 7 & 13 & 6 \\
\hline
\end{tabular}


Table 2. REE signatures of representative juvenile samples. Concentrations are in ppm.

\begin{tabular}{rrrrrrr}
\hline & Basalt & \multicolumn{3}{c}{ Andesite } & \multicolumn{3}{c}{ Dacite } \\
\hline La & JF-10 & JF-15 & JF-2a & JF-3b & JF-3f & JF-5c \\
Ce & 18.0 & 6.1 & 12.1 & 12.9 & 13.0 & 14.1 \\
Nd & 13.5 & 15.7 & 33.5 & 35.4 & 36.0 & 37.9 \\
Sm & 3.8 & 3.5 & 20.8 & 21.5 & 21.0 & 21.9 \\
Eu & 1.2 & 1.1 & 5.4 & 5.5 & 5.4 & 5.5 \\
Gd & 4.0 & 3.1 & 6.0 & 5.8 & 5.6 & 5.7 \\
Dy & 4.2 & 4.1 & 5.5 & 5.8 & 5.5 & 6.0 \\
Er & 2.2 & 1.9 & 3.4 & 3.4 & 3.3 & 3.5 \\
Yb & 2.3 & 2.1 & 3.3 & 3.5 & 3.4 & 3.6 \\
Lu & 0.3 & 0.3 & 0.5 & 0.5 & 0.5 & 0.5 \\
\hline
\end{tabular}


Table 3. Average chemical compositions of phenocrysts. Major elements are in wt $\%$. (Plg: Plagioclase; CPX: Clinopyroxene; OPX: Orthopyroxene; Fe-Ti: Fe-Ti oxide)

\begin{tabular}{|c|c|c|c|c|c|c|c|c|}
\hline & Basalt & & Andesite & & & & Dacite & \\
\hline & Plag & Olivine & Plag & CPX & $\overline{\text { OPX }}$ & Fe-Ti & Plag & OPX \\
\hline $\mathrm{SiO}_{2}$ & 49.73 & 38.00 & 48.92 & 51.38 & 52.40 & 0.78 & 55.62 & 52.08 \\
\hline $\mathrm{TiO}_{2}$ & - & - & - & 0.41 & 0.17 & 9.90 & - & 0.20 \\
\hline $\mathrm{Cr}_{2} \mathrm{O}_{3}$ & - & 0.05 & - & 0.01 & 0.07 & 0.12 & - & 0.06 \\
\hline $\mathbf{A l}_{2} \mathbf{O}_{3}$ & 30.74 & - & 31.73 & 1.71 & 1.49 & 2.31 & 27.23 & 1.54 \\
\hline MgO & - & 39.17 & - & 13.29 & 23.76 & 1.85 & - & 23.47 \\
\hline $\mathrm{Fe}_{2} \mathrm{O}_{3}$ & - & 0.00 & - & 1.07 & 2.62 & 48.32 & - & 2.15 \\
\hline $\mathrm{CaO}$ & 15.17 & 0.21 & 15.55 & 20.56 & 1.23 & 0.07 & 10.74 & 1.33 \\
\hline MnO & 0.01 & 0.31 & 0.01 & 0.46 & 0.79 & 0.45 & 0.03 & 0.72 \\
\hline FeO & 0.90 & 23.01 & 0.91 & 10.06 & 18.08 & 37.47 & 0.84 & 18.16 \\
\hline $\mathrm{Na}_{2} \mathrm{O}$ & 2.61 & - & 2.44 & 0.27 & - & - & 4.00 & 0.01 \\
\hline $\mathbf{K}_{2} \mathbf{O}$ & 0.10 & - & 0.09 & - & - & - & 0.49 & - \\
\hline $\mathrm{NiO}$ & & 0.12 & - & - & - & _ & - & \\
\hline Total & 99.26 & 100.85 & 99.65 & 99.23 & 100.61 & 101.93 & 98.95 & 99.71 \\
\hline
\end{tabular}


Table 4. $\mathrm{Sr}, \mathrm{Nd}$, and $\mathrm{Pb}$ isotopic compositions of representative juvenile and xenolith samples. Strontium isotopic ratios were corrected for fractionation using ${ }^{86} \mathrm{Sr} /{ }^{88} \mathrm{Sr}=0.1194$. NBS 987 gave an average of ${ }^{87} \mathrm{Sr} /{ }^{86} \mathrm{Sr}=0.710241 \pm 1$ $(\mathrm{n}=80)$. Neodymium isotopic ratios were corrected for fractionation using ${ }^{144} \mathrm{Nd} /{ }^{146} \mathrm{Nd}=0.7219$. La Jolla gave an average of ${ }^{144} \mathrm{Nd} /{ }^{143} \mathrm{Nd}=0.51185 \pm 1$ ( $\mathrm{n}=50) .{ }^{206} \mathrm{~Pb} /{ }^{204} \mathrm{~Pb},{ }^{207} \mathrm{~Pb} /{ }^{204} \mathrm{~Pb}$, and ${ }^{208} \mathrm{~Pb} /{ }^{204} \mathrm{~Pb}$ were corrected for fractionation by $0.1 \%, 0.1 \%$, and $0.125 \%$ per amu respectively. Errors on ${ }^{206} \mathrm{~Pb} /{ }^{204} \mathrm{~Pb},{ }^{207} \mathrm{~Pb} /{ }^{204} \mathrm{~Pb}$, and ${ }^{208} \mathrm{~Pb} /{ }^{204} \mathrm{~Pb}$ measurements were $\pm 0.006, \pm 0.008$, and \pm 0.026 respectively.

\begin{tabular}{lrrrrrr}
\hline & Basalt & \multicolumn{3}{c}{ Andesite } & \multicolumn{3}{c}{ Dacite } \\
\hline & \multicolumn{1}{c}{ JF-10 } & \multicolumn{1}{c}{ JF-15 } & \multicolumn{1}{c}{ JF-2a } & \multicolumn{1}{c}{ JF-3b } & \multicolumn{1}{c}{ JF-3f } & \multicolumn{1}{c}{ Jf-5c } \\
\hline${ }^{{ }^{87} \mathbf{S r}} /{ }^{\mathbf{8}} \mathbf{S r}$ & 0.7034 & 0.7034 & 0.7034 & 0.7034 & 0.7034 & 0.7034 \\
${ }^{\mathbf{1 4 4}} \mathbf{N d} /{ }^{\mathbf{1 4 3}} \mathbf{N d}$ & 0.51304 & 0.51304 & 0.51304 & 0.51304 & 0.51304 & 0.51304 \\
${ }^{206} \mathbf{P b} /{ }^{\mathbf{2 0 4}} \mathbf{P b}$ & 18.284 & 18.284 & 18.269 & 18.257 & 18.250 & 18.241 \\
${ }^{207} \mathbf{P b} /{ }^{\mathbf{2 0 4}} \mathbf{P b}$ & 15.511 & 15.513 & 15.510 & 15.502 & 15.504 & 15.502 \\
${ }^{208} \mathbf{P b} /{ }^{\mathbf{2 0 4}} \mathbf{P b}$ & 38.208 & 38.214 & 38.200 & 38.166 & 38.168 & 38.157 \\
\hline
\end{tabular}

\begin{tabular}{lrrrr}
\hline & \multicolumn{2}{c}{ Xenolith: basalt } & \multicolumn{2}{c}{ Xenolith: gabbro } \\
\hline & \multicolumn{1}{c}{ JF-6b } & \multicolumn{1}{c}{ JF-6c } & \multicolumn{1}{c}{ JF-7b } & \multicolumn{1}{c}{ Jf-8b } \\
\hline${ }^{87} \mathbf{S r} /{ }^{\mathbf{8 6}} \mathbf{S r}$ & 0.7034 & 0.7034 & 0.7034 & 0.7034 \\
${ }^{144} \mathbf{N d} /{ }^{\mathbf{1 4 3}} \mathbf{N d}$ & 0.51304 & 0.51305 & 0.51304 & 0.51304 \\
${ }^{206} \mathbf{P b} /{ }^{\mathbf{2 0 4}} \mathbf{P b}$ & 18.277 & 18.263 & & \\
${ }^{207} \mathbf{P b} /{ }^{\mathbf{2 0 4}} \mathbf{P b}$ & 15.519 & 15.512 & & \\
${ }^{208} \mathbf{P b} /{ }^{\mathbf{2 0 4}} \mathbf{P b}$ & 38.228 & 38.181 & & \\
\hline
\end{tabular}


Table 5. Os isotopic compositions of representative juvenile samples. Internal measurement errors ranged from $0.5-2 \%$. Blank correction errors (shown in the data table) ranged from $0.6-10 \%$ based on blanks of $1.0 \pm 0.1 \mathrm{pg}$ and ${ }^{187} \mathrm{Os} /{ }^{188} \mathrm{Os}=0.174$. Replicate analyses (JF-15 and JF-15R) agreed within $3.6 \%$ for ${ }^{187} \mathrm{Os} /{ }^{188} \mathrm{Os}$.

\begin{tabular}{|c|c|c|c|c|c|c|}
\hline & Basalt & & & Andesite & Dacite & \\
\hline & JF-10 & JF-15 & JF-15R & JF-3b & JF-3f & Jf-5c \\
\hline$\overline{\text { Os p }}$ & 0.0024 & 0.0015 & 0.0025 & 0.0003 & 0.0003 & 0.0003 \\
\hline${ }^{187} \mathrm{Os} /$ & $0.174 \pm 1$ & $0.165 \pm 1$ & $0.171 \pm 1$ & $0.26 \pm 1$ & $0.39 \pm 4$ & $0.30 \pm 2$ \\
\hline
\end{tabular}


Table 6. The calculated fractionating mineral assemblages with the relative mineral proportions. (pl: plagioclase, ol: olivine; cpx; clinopyroxene, opx: orthopyroxene; TiFe: Ti-Fe oxide; ap: apatite; FC\%: percentage of fractional crystallization obtained by major element modeling)

\begin{tabular}{lllrlr}
\hline Basalt & \multicolumn{3}{l}{ Andesite } & Dacite \\
\hline $\mathrm{pl}$ & $55.6 \%$ & $\mathrm{pl}$ & $60.4 \%$ & $\mathrm{pl}$ & $67.4 \%$ \\
$\mathrm{cpx}$ & $22.2 \%$ & opx & $21.7 \%$ & opx & $13.7 \%$ \\
$\mathrm{ol}$ & $12.1 \%$ & $\mathrm{mt}$ & $10.7 \%$ & $\mathrm{mt}$ & $9.1 \%$ \\
$\mathrm{mt}$ & $10.1 \%$ & $\mathrm{cpx}$ & $6.6 \%$ & $\mathrm{cpx}$ & $8.8 \%$ \\
& & ap & $0.6 \%$ & ap & $1.0 \%$ \\
\%FC & $45.8 \%$ & \% FC & $26.9 \%$ & \% FC & $17.2 \%$ \\
\hline
\end{tabular}




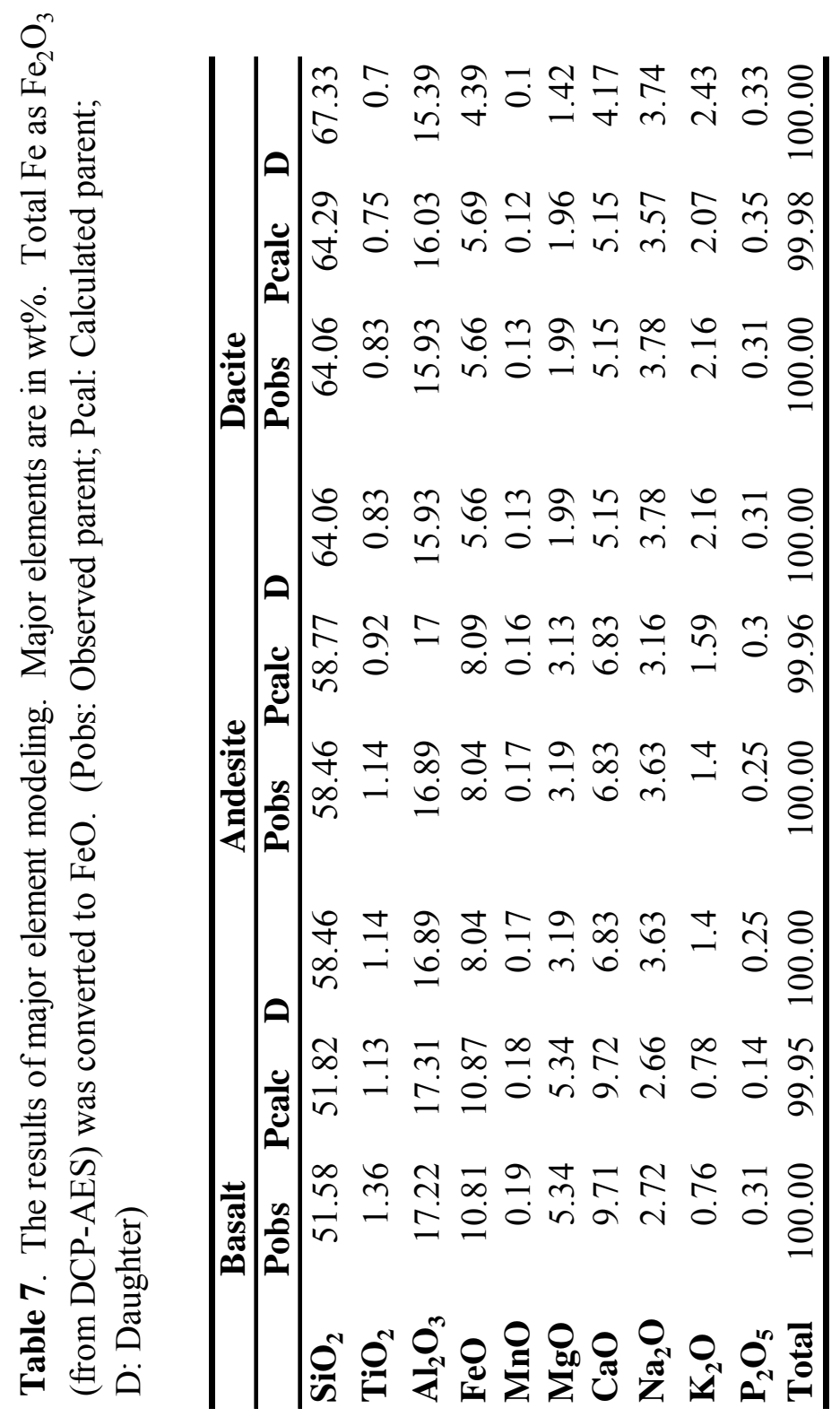




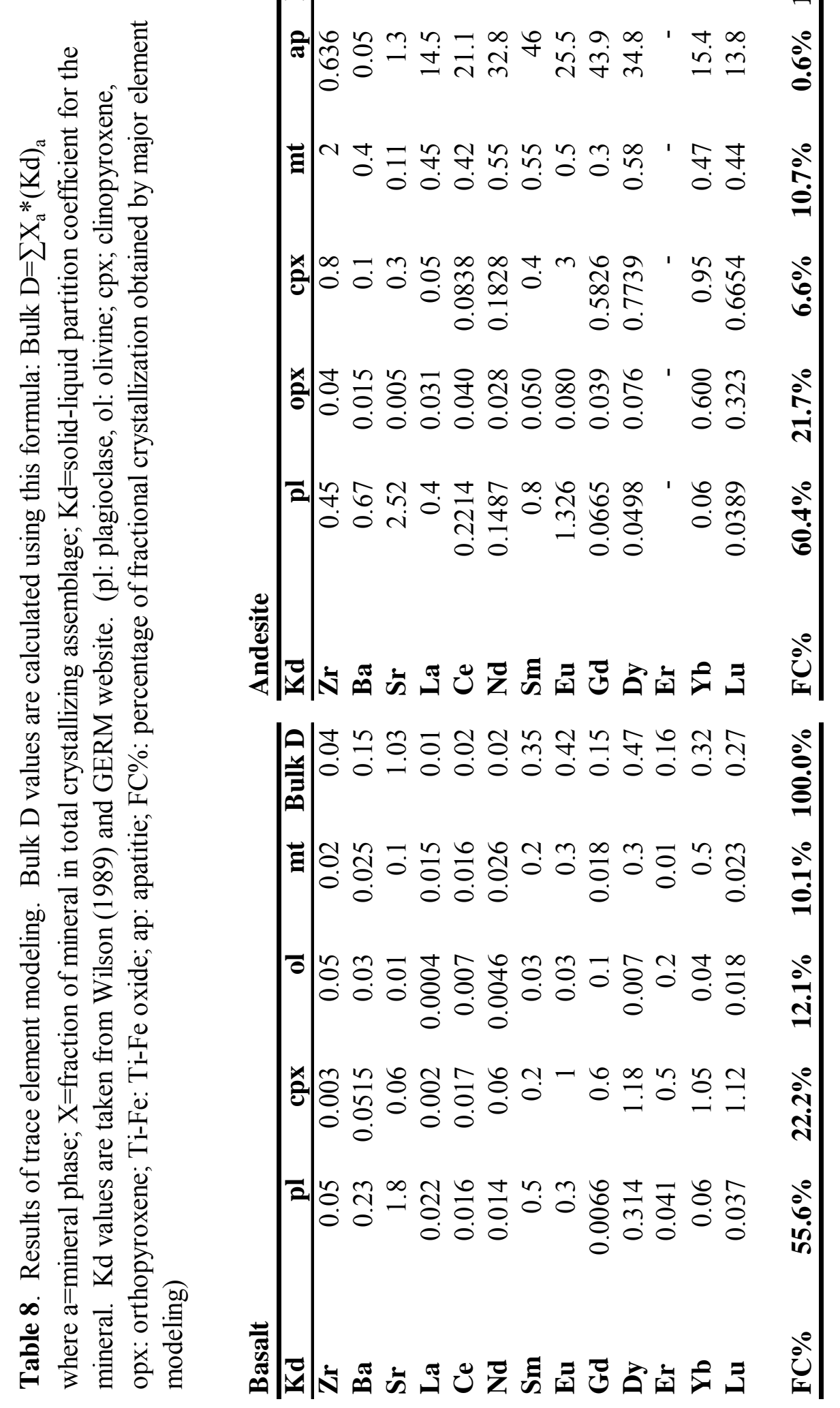




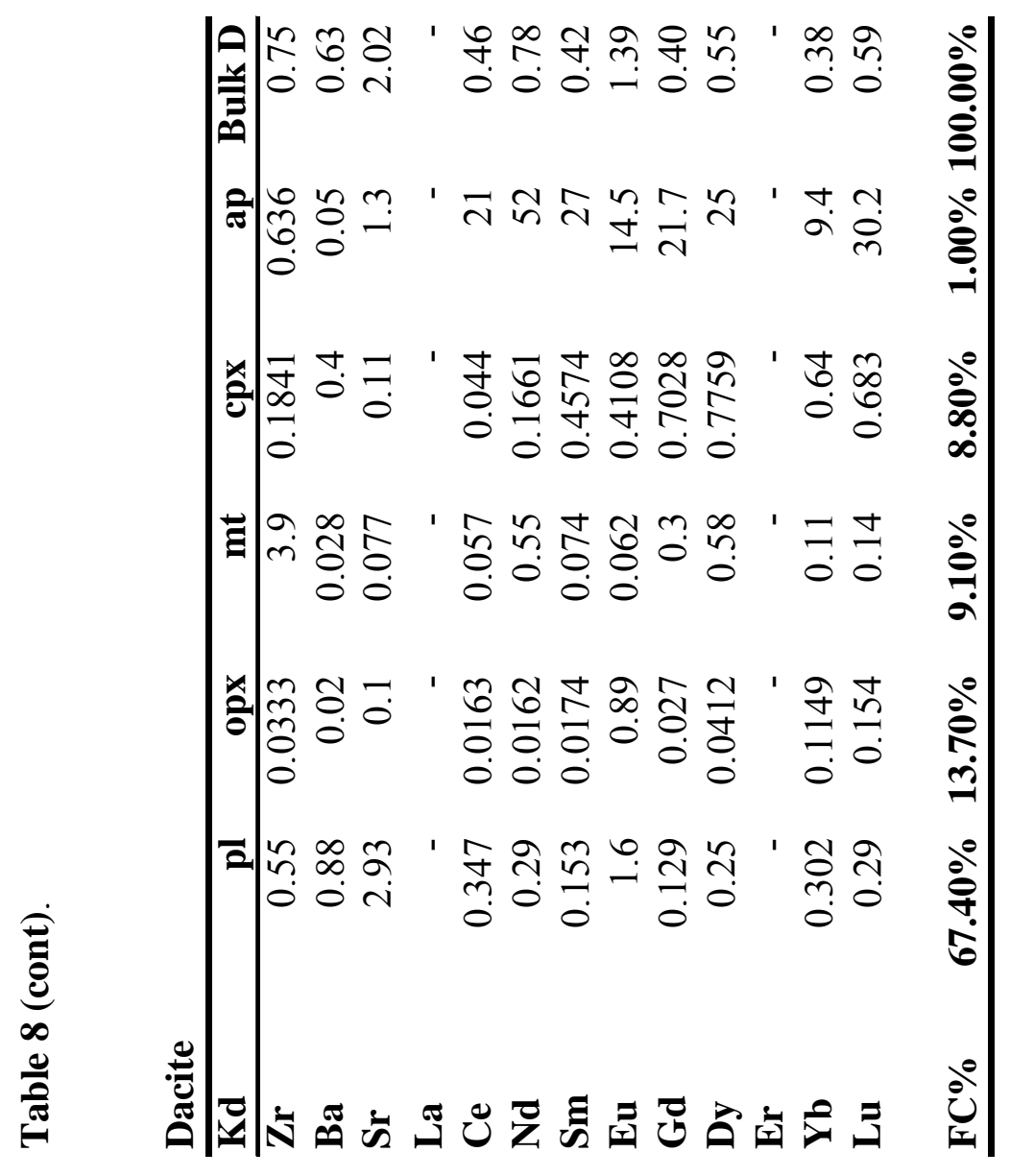




\section{References}

Aihara, J. (2003) Eruption of Mt. Fuji: http://www2s.biglobe.ne.jp/ aaihara/erution.htm (Japanese).

Aramaki, S. \& Ui, T. (1982) Japan. In: Thorpe, S.R. (ed). Andesites Orogenic Andesites and Related Rocks. John Wiley \& Sons, Ltd., Great Britain.

Arculus, R.J., Gust, D.A. \& Kushiro, I. (1991) The evolution of Fuji and Hakone Volcanoes Honshu: Research and Exploration: a scholarly publication of the National Geographic Society 7 (3), 276-309.

Asahi Newspaper. (2001) The eruption of Fuji Volcano. Asahi Newspaper, 4 June (Japanese).

Bailey, D.K. (1970) Volatile flux, heat focusing and the generation of magma. Geology Journal Special Issue 2, 177-186.

BenOthman, D.B. White, W.M. \& Patchett, J. (1989) The geochemistry of marine sediments, island arc magma genesis, and crust-mantle recycling. Earth and Planetary Science Letters 94: 1-21.

Blake, S. (1984) Volatile oversaturation during the evolution of silicic magma chambers as an eruption tripper. Journal of Geophysical Research 89, 8237-8244.

Bowen, N.L. (1928) The evolution of the igneous rocks: Princeton, N.J., Princeton Univ. Press, pp. 332.

Carr, M. (2000) Igpet 2000 for Win95/89/NT. Terra Softa Inc.

Cameron, K.L. (1984) Bishop Tuff revisited: new rare earth element data consistent with crystal fractionation. Science 224, 1338-1340. 
Christensen, J.N. \& Halliday, A.N. (1996) Rb-Sr ages and Nd isotopic compositions of melt inclusions from the Bishop Tuff and the generation of silicic magma. Earth and Planetary Science Letters 144, 547-561.

Cohen, A.S. \& Waters, F.G. (1996) Separation of osmium from geological materials by solvent extraction for analysis by thermal ionisation mass spectrometry, Analytical Chimica Acta 332, 269-275.

De, A. (1974) Silicate liquid immiscibility in the Deccan Traps and its petrogenetic significance. Geological Society of America Bulletin 85, 471-474.

Duffield, W.A., Ruiz, J. \& Webster, J.C. (1995) Roof-rock contamination of magma along the top of the reservoir for the Bishop Tuff. Journal of Volcanology and Geothermal Research 69, 187-195.

Esser, B.K. \& Turekian, K.K. (1993) The osmium isotopic composition of the continental crust, Geochimica et Cosmochimica Act 57, 3093-3104.

Fujii, T., Kushiro, I., Nakamura, Y. \& Koyaguchi, T. (1980) A note on silicate liquid immiscibility in Japanese volcanic rocks. Journal of the Geological Society of Japan 86 (6), 409-412.

Geological Survey of Japan, http://www.aist.go.jp/RIODB/geostand/welcome.html.

GERM, http://earthref.org/GERM/tools/petrology.

Greig, J.W. (1927) Immiscibility in silicate melts. American Journal of Science (ser. 5) 13, 1-44, 133-154. 
Hildreth, W., Elston, W.E., editor. "The Bishop Tuff; evidence for the origin of compositional zonation in silicic magma chambers.” Special Paper - Geological Society of America, issue 180, 1979, p. 43-75.

Ito, E., White, W.M. \& Gopel, C. (1987) The O, Sr, Nd and Pb isotope geochemistry of MORB. Chemical Geology 62: 157-176.

Katoh, S., Danhara, T., Hart, W.K. \& Gabriel, G.W. (1999) Use of sodium polytungstate solution in the purification of volcanic glass shards for bulk chemical analysis. Nature and Human Activities 4: 45-54.

Kawamoto, T. (1992) Liquid immiscibility in the Fuji 1707 calc-alkaline magma chamber, Japan. International Geological Congress (Abstract) 29, 558.

Kawamoto, T. (1991a) Liquid immiscibility in the Fuji 1707 calc-alkaline magma chamber, Japan. American Geophysical Union (Abstract) 52, 575.

Kawamoto, T. (1991b) Mechanism for the formation of the Fuji 1707 magma chamber, Japan: Liquid immiscibility in calc-alkaline magmas. The Volcanological Society of Japan (Abstract) (2), 169.

Kawamoto, T. (1990) Liquid immiscibility in a calc-alkaline magma chamber, the Hoei Tephra, Fuji Volcano, Japan. American Geophysical Union (Abstract) 31, 952 (Japanese).

Knesel, K.M. \& Davidson, J.P. (1997) The origin and evolution of large-volume silicic magma systems; Long Valley Caldera. International Geology Review 39 (11), 1033-1052.

Kondo, H., Shuto, K. \& Fukase, M. (2000) An AFC (assimilation and fractional crystallization) process as the petrogenesis of andesites from the Pliocene Myojin-iwa Formation, the back-arc side of the Northeast Japan: combined major-and trace-element and Sr-Nd isotope constraints. Journal of Geological Society of Japan 106: 426-441. 
Koyama, M. (1998) Reevaluation of the eruptive history of Fuji Volcano, Japan, mainly based on historical documents. Bulletin of the Volcanological Society of Japan 43 (5), 323-347 (Japanese with English abstract).

Kuentz, D.C. (1986) The Otowi Member of the Bandelier Tuff: a Study of the Petrology, Petrography, and Geochemistry of an Explosive Silicic Eruption, Jemez Mountains, New Mexico. M.Sc. thesis, University of Texas, Arlington, TX.

LeBas, M.J., LeMaitre, R.W., Streckeisen, A. \& Zanettin, B.A. (1986) Chemical classification of volcanic rocks based on the total alkali-silica diagram. Journal of Petrology 27 (3), 745750.

Machida, H. (1981) Fuji volcano. Tephrochronological study. In: Aramaki, S. (ed): Field Excursion Guide to Fuji Volcano, pt. 1. Symposium on Arc Volcanism, Tokyo and Hakone, Japan. Volcanological Society of Japan, Tokyo, 13-21.

Machida, H. (1967) The Recent development of the Fuji Volcano, Japan: Geographical Reports of Tokyo Metropolitan University 2, 11-20 (Japanese with English Abstract).

Machida, H. \& Moriyama, A. (1968) The development of Mount Fuji and Mount Hakone volcanoes analyzed from the tephrochronological study in the Ooiso hills. Geographical Review of Japan (Series B) 41 (4), 241-257.

Michael, P.J. (1983) Chemical differentiation of the Bishop Tuff and other high-silica magmas through crystallization processes. Geology 11, 31-34.

Miyaji, N. (1990) History of Fuji Volcano: Mainly Younger Fuji Volcano. The Volcanological Society of Japan (Abstract) (1), 5-6 (Japanese). Miyaji, N. (1993) The characteristics of eruptive materials from Fuji 1707 eruption. (Report/Abstract), 111-113 (Japanese). 
Miyaji, N. (1988) History of Younger Fuji Volcano. Journal of Geological Society of Japan 94 (6), 433-452 (Japanese with English Abstract).

Miyaji N. (1984) Wind effect on the dispersion of the Fuji 1707 tephra. Bulletin of Volcanological Society of Japan 29: 17-30.

Nakamura, N. (1974) Determination of REE, Ba, Fe, Mg, Na and K in carbonaceous and ordinary chondrites. Geochimica et Cosmochimica Acta 38 (5), 757-775

Nakamura, T., Banju, M., Sato, J. \& Takahashi, H. (1986) Compositional variation within the 1707 fallout tephra from Fuji Volcano. Bulletin of the Volcanological Society of Japan 31 (4), 253-264 (Japanese with English abstract).

Ogawa, Y., Tamaki, K., Isozaki, Y. \& Shikazono, N. (1997) Japan. In: Moores, E.M. and Fairbridge, R. (ed) Encyclopedia of Earth Sciences Series: Encyclopedia of European and Asian Regional Geology, pp. 436-499.

Peucker-Ehrenbrink, B. \& Jahn, B. (2001) Rhenium-osmium isotope systematics and platinum group element concentrations: Loess and the upper continental crust. Geochemistry Geophysics Geosystems 2, 2001GC000172.

Philpotts, A.R. (1979) Silicate liquid immiscibility in Tholeiitic Basalts. Journal of Petrology 20 (1), 99-118.

Philpotts, A.R. \& Doyle, C.D. (1983) Effect of magma oxidation state on the extent of silicate liquid immiscibility in a tholeiitic basalt. American Journal of Science 283, 967-986.

Piccoli, P.M. \& Candela, P.A. (2002) Apatite in Igneous System. In: Kohn, M.J., Rakovan, J. \& Hughes, J.M. (ed) Reviews in Mineralogy and Geochemistry 48. Mineralogical Society of America, Washington, DC, pp 225-292. 
Pin, C. \& Zalduegui, J.F.S. (1997) Sequential separation of light rare-earth elements, thorium and uranium by miniaturized extraction chromatography: application to isotopic analyses of silicate rocks. Analytica Chimica Acta 339, 79-89.

Reid, M.R. \& Coath, C.D. (2000) In situ U-Pb ages of zircons from the Bishop Tuff; no evidence for long crystal residence times. Geology (Boulder) 28 (5), 443-446.

Rezanov, A.I., Shuto, K., Iizumi, S. \& Shimura, T. (1999) Sr and Nd isotopic and geochemical characteristics of Cretaceous Paleogene granitoid rocks in the Niigata area, the northernmost part of the Southwest Japan. Mem. Geol. Soc. Japan 53, 269-297.

Roedder, E. \& Weiblen, P.W. (1971) Petrology of silicate melt inclusions, Apollo 11 and 12 and terrestrial equivalents. In Second Lunar Sci. Conf. Proc. Ibid., Suppl. 2 (1), 507-528.

Roedder, E. \& Weiblen, P.W. (1970) Lunar petrology of silicate melt inclusions, Apollo 11 rocks. In Apollo 11 Lunar Sci. Conf. Proc. Geochim. Cosmochim. Acta, Suppl, 1 (1), 801-837.

Roy-Barman, M. (1993) Mesure du rapport ${ }^{187} \mathrm{Os} /{ }^{186} \mathrm{Os}$ dans les basalts et peridotites: contribution a la systematique ${ }^{187} \mathrm{Re} /{ }^{186}$ Os dans le manteau, Thesis, Univ. Paris 7.

Roy-Barman, M. \& Allegre, C.J. (1995) ${ }^{187} \mathrm{Os} /{ }^{186}$ Os in ocean island basalts: tracing oceanic crust recycling in the mantle, Earth and Planetary Science Letters 129, 145-161.

Shirey, S.B. \& Walker, R.J. (1998) The Re-Os isotope system in cosmochemistry and hightemperature geochemistry, Annual Reviews of Earth and Planetary Science, 26, 423-500.

Spell, T.L., Harrison, T.M. \& Wolff, J.A. (1990) ${ }^{40} \mathrm{Ar} /{ }^{39} \mathrm{Ar}$ dating of the Bandelier Tuff and San Diego Canyon ignimbrites: temporal constraints on magmatic evolution. Journal of Volcanology and Geothermal Research 43, 175-193. 
Taira, A. (2001) Tectonic evolution of the Japanese island arc system. Annual Review Earth Planetary Science 29, 109-134.

Takahashi, M., Hasegawa, Y., Tsukui, M. \& Nemoto, Y. (1991) Evolution of magma-plumbing system beneath Fuji Volcano: On the viewpoint of whole-rock chemistry. Bulletin of the Volcanological Society of Japan 36 (2), 281-296 (Japanese with English abstract).

Togashi, S. (1990) Geochemical history of Fuji Volcano and constraint on the model of magma chamber. The Volcanological Society of Japan (Programme and Abstracts)(1) p. 10. (Japanese).

Togashi, S. \& Yamazaki, H. (1990) Geochemical evolution of Fuji Volcano, Japan. International Conference on Geochronology Cosmochronology and Isotope Geology (Abstracts) 27, 101.

Togashi, S., Miyaji, N. \& Yamazaki, H., (1991) Fractional crystallization in large tholeiitic magma chamber during the early stage of the Younger Fuji Volcano, Japan. Bulletin of the Volcanological Society of Japan 36 (2), 262-280 (Japanese with English abstract).

Tsuya, H. (1968) Geology of Volcano Mt. Fuji. Geological Survey of Japan, pp 24.

Tsuya, H. (1955) Geological and petrological studies of Volcano Fuji V., On the 1707 eruption of Volcano Fuji. Bulletin of Earthquake Research Institute 33, 341-383.

Tsuya, H. (1940) Geological and petrological studies of Volcano Fuji III., Geology of the southwestern foot of Volcano Fuji. Bulletin of earthquake Research Institute 18, 419-445 (Japanese with English abstract).

Walker, R.J., Carlson, R.W., Shirey, S.B. \& Boyd, S.B. (1989) Os, Sr, Nd and Pb isotope systematics of southern African peridotite xenoliths: implications for the chemical evolution of subcontinental mantle. Geochimica et Cosmochimica Acta 53, 1583-1595. 
Weather Observatory, 2001, The Summary of the 1707 eruption of Fuji Volcano: Fuji Volcano WG (report/abstract), p. 1-7 (Japanese).

Widom, E. (1997) Sources of ocean island basalts: a review of the osmium isotope evidence. Physica A 244, 484-496.

Widom, E. \& Shirey, S.B. (1996) Os isotope systematics in the Azores: implications for mantle plume sources. Earth and Planetary Science Letters 142, 451-465.

Widom, E., Kepezhinskas, P. \& Defant, M. (2003a) The nature of metasomatism in the sub-arc mantle wedge: evidence from Re-Os isotopes in Kamchatka peridotite xenoliths. Chemical Geology 196, 283-306.

Widom, E., Kepezhinskas, P. \& Defant, M. (2003b) Os and Sr isotope signatures in Kamchatka Adakites, Nb-rich arc basalts and mantle pyroxenites: inferences on mantle and crustal processes. EOS Abst vol. San Francisco.

Widom, E., Gill, J.B. \& Schmincke, H.U. (1992). Processes and timescales in the evolution of chemically zoned trachyte; Fogo A, Sao Miguel, Azores. Contributions to Mineralogy and Petrology 111 (3), 311-328.

Widom, E., Hoernle, K.A., Shirey, S.B. \& Schmincke, H.U. (1999) Os isotope systematics in the Canary Islands and Madeira: lithospheric contamination and mantle plume signatures. Journal of Petrology 40 (2), 279-296.

Wilson, M. (1989) Igneous Petrogenesis: A Global Tectonic Approach. Unwin Hyman Ltd, London.

Wolff, J.A. \& Ramos, F.C. (2003) Pb isotope variations among Bandelier Tuff feldspars: No evidence for a long-lived silicic magma chamber. Geology 31 (6), 533-536. 
Wolff, J.A., Ramos, F.C. \& Davidson, J.P. (1999) Sr disequilibrium during differentiation of the Bandelier Tuff: constraints on the crystallization of a large rhyolitic magma chamber. Geology 27, 495-498.

Wörner, G. and Schmincke, H.U. (1984) Mineralogical and Chemical Zonation of the Laacher See Tephra Sequence (East Eifel, W. Germany). Journal of Petrology 25 (4), 805-835.

Wörner, G. \& Wright T.L. (1984) Evidence for magma mixing within the Laacher See magma chamber (East Eifel, Germany). Journal of Volcanology and Geothermal Research 22, 301-327.

Wörner, G., Staudigel, H. \& Zindler, A. (1985) Isotopic constraints on open system evolution of Laacher See magma chamber (Eifel, West Germany). Earth and Planetary Science Letter 75, 37-49.

Wörner, G., Beusen, J.M., Duchateau, N., Gijbels, R. and Schmincke, H.U. (1983) Trace element abundances and mineral/melt distribution coefficients in phonolites from the Laacher See Volcano (Germany). Contributions to Mineralogy and Petrology 84, 152-173. 
Appendix 1. The Fuji 1707 Sample Processing Procedures.

\begin{tabular}{|c|c|c|c|c|c|c|c|}
\hline & HC & US bath & $\mathrm{JC}$ & $\overline{\text { DM }}$ & $\overline{\text { SB }}$ & R-Type & Thin secion \\
\hline JF-1 & n & $15 \mathrm{~m} \times 2$ & metal & $n$ & $\mathrm{BM}$ & x:gabbro & - \\
\hline JF-2a & $\mathrm{pl}$ & $15 \mathrm{~m} \times 4$ & $\mathrm{y}$ & $\mathrm{n}$ & $\mathrm{y}$ & andesite & polished \\
\hline JF-2b & $\mathrm{pl}$ & $15 \mathrm{~m} \times 4$ & $\mathrm{y}$ & $\mathrm{n}$ & $\mathrm{y}$ & andesite & - \\
\hline JF-2c & $\mathrm{pl}$ & $15 \mathrm{~m} \times 4$ & $\mathrm{y}$ & $\mathrm{n}$ & $\mathrm{y}$ & andesite & - \\
\hline JF-2d & $\mathrm{pl}$ & $15 \mathrm{~m} \times 4$ & $\mathrm{y}$ & $\mathrm{n}$ & $\mathrm{y}$ & andesite & - \\
\hline JF-2e & $\mathrm{pl}$ & $15 \mathrm{~m} \times 4$ & $\mathrm{y}$ & $\mathrm{n}$ & $\mathrm{y}$ & andesite & - \\
\hline JF-2f & $\mathrm{pl}$ & $15 \mathrm{~m} \times 4$ & $\mathrm{y}$ & $\mathrm{n}$ & $\mathrm{y}$ & dacite & polished \\
\hline JF-3a & $\mathrm{pl}$ & $15 \mathrm{~m} \times 4$ & $\mathrm{y}$ & $\mathrm{n}$ & $\mathrm{y}$ & andesite & - \\
\hline JF-3b & $\mathrm{pl}$ & $15 \mathrm{~m} \times 4$ & $\mathrm{y}$ & $\mathrm{n}$ & $\mathrm{y}$ & andesite & polished \\
\hline JF-3c & $\mathrm{pl}$ & $15 \mathrm{~m} \mathrm{X} 4$ & $\mathrm{y}$ & $\mathrm{n}$ & $\mathrm{y}$ & andesite & - \\
\hline JF-3d & $\mathrm{pl}$ & $15 \mathrm{~m} \times 4$ & $\mathrm{y}$ & $\mathrm{n}$ & $\mathrm{y}$ & andesite & unpolished \\
\hline JF-3e & $\mathrm{pl}$ & $15 \mathrm{~m} \times 4$ & $\mathrm{y}$ & $\mathrm{n}$ & $\mathrm{y}$ & andesite & - \\
\hline JF-3f & $\mathrm{pl}$ & $15 \mathrm{~m} \times 4$ & $\mathrm{y}$ & $\mathrm{n}$ & $\mathrm{y}$ & dacite & polished \\
\hline JF-4a & $\mathrm{pl}$ & $15 \mathrm{~m} \times 4$ & $\mathrm{y}$ & $\mathrm{n}$ & $\mathrm{y}$ & andesite & unpolished \\
\hline JF-4b & $\mathrm{pl}$ & $15 \mathrm{~m} \times 4$ & $\mathrm{y}$ & $\mathrm{n}$ & $\mathrm{y}$ & andesite & - \\
\hline JF-4c & $\mathrm{n}$ & $15 \mathrm{~m} \times 2$ & metal & $\mathrm{n}$ & $\mathrm{BM}$ & x:gabbro & - \\
\hline JF-4d & $\mathrm{pl}$ & $15 \mathrm{~m} \times 4$ & $\mathrm{y}$ & $\mathrm{n}$ & $\mathrm{y}$ & andesite & - \\
\hline JF-4e & $\mathrm{pl}$ & $15 \mathrm{~m} \times 4$ & $\mathrm{y}$ & $\mathrm{n}$ & $\mathrm{y}$ & dacite & polished \\
\hline JF-4f & $\mathrm{pl}$ & $15 \mathrm{~m} \times 4$ & $\mathrm{y}$ & $\mathrm{n}$ & $\mathrm{y}$ & andesite & unpolished \\
\hline JF-5a & $\mathrm{pl}$ & $15 \mathrm{~m} \times 4$ & $\mathrm{y}$ & $\mathrm{n}$ & $\mathrm{y}$ & andesite & unpolished \\
\hline JF-5b & $\mathrm{pl}$ & $15 \mathrm{~m} \times 4$ & $\mathrm{y}$ & $\mathrm{n}$ & $\mathrm{y}$ & andesite & - \\
\hline JF-5c & $\mathrm{pl}$ & $15 \mathrm{~m} \times 4$ & $\mathrm{y}$ & $\mathrm{n}$ & $\mathrm{y}$ & dacite & polished \\
\hline JF-5d & $\mathrm{pl}$ & $15 \mathrm{~m} \times 4$ & $\mathrm{y}$ & $\mathrm{n}$ & $\mathrm{y}$ & dacite & - \\
\hline JF-6a & sp & $15 \mathrm{~m} \times 2$ & metal & y x 1 & $\mathrm{y}$ & $\mathrm{x}$ :basalt & - \\
\hline JF-6b & sp & $15 \mathrm{~m} \times 2$ & metal & y x 1 & $\mathrm{y}$ & $\mathrm{x}$ :basalt & - \\
\hline JF-6c & $\mathrm{pl}$ & $15 \mathrm{~m} \times 2$ & metal & $\mathrm{y} \times 2$ & $\mathrm{y}$ & $\mathrm{x}$ :basalt & unpolished \\
\hline JF-6d & $\mathrm{pl}$ & $15 \mathrm{~m} \times 2$ & metal & y x 2 & $\mathrm{y}$ & $\mathrm{x}$ :basalt & unpolished \\
\hline JF-7a & $n$ & $15 \mathrm{~m} \times 2$ & metal & y x 1 & $\mathrm{y}$ & $\mathrm{x}$ :basalt & - \\
\hline JF-7b & $\mathrm{n}$ & $15 \mathrm{~m} \times 2$ & metal & $\mathrm{y} \times 1$ & $\mathrm{y}$ & x:gabbro & - \\
\hline JF-8a & $n$ & $15 \mathrm{~m} \times 2$ & metal & y x 1 & $\mathrm{y}$ & $\mathrm{x}$ :basalt & - \\
\hline JF-8b & $n$ & $15 \mathrm{~m} \times 2$ & metal & $\mathrm{n}$ & $\mathrm{BM}$ & x:gabbro & - \\
\hline JF-9a & $\mathrm{pl}$ & $15 \mathrm{~m} \times 2$ & metal & $\mathrm{y} \times 2$ & $\mathrm{y}$ & x:gabbro & unpolished \\
\hline JF-9b & $\mathrm{pl}$ & $15 \mathrm{~m} \times 2$ & metal & $\mathrm{y} \times 2$ & $\mathrm{y}$ & $\mathrm{x}$ :basalt & unpolished \\
\hline JF-10 & $n$ & $15 \mathrm{~m} \times 4$ & $\mathrm{y}$ & $\mathrm{n}$ & $\mathrm{y}$ & basalt & polished \\
\hline JF-11 & $n$ & $15 \mathrm{~m} \times 4$ & $\mathrm{y}$ & $\mathrm{n}$ & $\mathrm{y}$ & basalt & unpolished \\
\hline JF-12 & $n$ & $15 \mathrm{~m} \times 4$ & $\mathrm{y}$ & $\mathrm{n}$ & $\mathrm{y}$ & basalt & polished \\
\hline JF-13 & $n$ & $15 \mathrm{~m} \times 4$ & $\mathrm{y}$ & $\mathrm{n}$ & $\mathrm{y}$ & basalt & unpolished \\
\hline JF-14 & $n$ & $15 \mathrm{~m} \times 4$ & $\mathrm{y}$ & $\mathrm{n}$ & $\mathrm{y}$ & basalt & unpolished \\
\hline JF-15 & $n$ & $15 \mathrm{~m} \times 4$ & $\mathrm{y}$ & $\mathrm{n}$ & $\mathrm{y}$ & basalt & polished \\
\hline JF-16 & $n$ & $15 \mathrm{~m} \times 4$ & $\mathrm{y}$ & $\mathrm{n}$ & $\mathrm{y}$ & basalt & unpolished \\
\hline JF-17 & $\mathrm{n}$ & $15 \mathrm{~m} \times 4$ & $\mathrm{y}$ & $\mathrm{n}$ & $\mathrm{y}$ & basalt & polished \\
\hline
\end{tabular}




\begin{tabular}{|c|c|c|c|c|c|c|c|}
\hline & $\overline{\mathrm{HC}}$ & US bath & JC & $\overline{D M}$ & SB & R-Type & Thin secion \\
\hline JF-18 & $\mathrm{n}$ & $15 \mathrm{~m} \times 4$ & $\mathrm{y}$ & $\mathrm{n}$ & $\mathrm{y}$ & basalt & unpolished \\
\hline JF-19 & $\mathrm{n}$ & $15 \mathrm{~m} \times 4$ & hc (pl) & $\mathrm{n}$ & $\mathrm{y}$ & basalt & polished \\
\hline JF-20L & $\mathrm{n}$ & $15 \mathrm{~m} \times 4$ & hc (pl+pa) & $\mathrm{n}$ & $\mathrm{y}$ & andesite & polished \\
\hline JF-20D & $\mathrm{n}$ & $15 \mathrm{~m} \times 4$ & hc (pl+pa) & $\mathrm{n}$ & y & andesite & polished \\
\hline JF-21V & $\mathrm{n}$ & $15 \mathrm{~m} \times 4$ & $\mathrm{y}$ & $\mathrm{n}$ & $\mathrm{y}$ & dacite & polished \\
\hline JF-21L & $\mathrm{n}$ & $15 \mathrm{~m} \times 4$ & $\mathrm{y}$ & $\mathrm{n}$ & $\mathrm{y}$ & andesite & unpolished \\
\hline JF-21D & $\mathrm{n}$ & $15 \mathrm{~m} \times 4$ & $\mathrm{y}$ & $\mathrm{n}$ & $\mathrm{y}$ & andesite & unpolished \\
\hline JF-21B & $\mathrm{n}$ & $15 \mathrm{~m} \times 4$ & $\mathrm{y}$ & $\mathrm{n}$ & $\mathrm{y}$ & andesite & polished \\
\hline
\end{tabular}

HC: hand crush using a rock hammer; SP: steel splitter; US bath: ultrasonic bath; JC: alumina jaw crusher;DM: alumina discmill; SB: alumina shatter box; BM: alumina ball mill; pl: plastic; pa: paper; y: yes; n: no; x: xenolith 


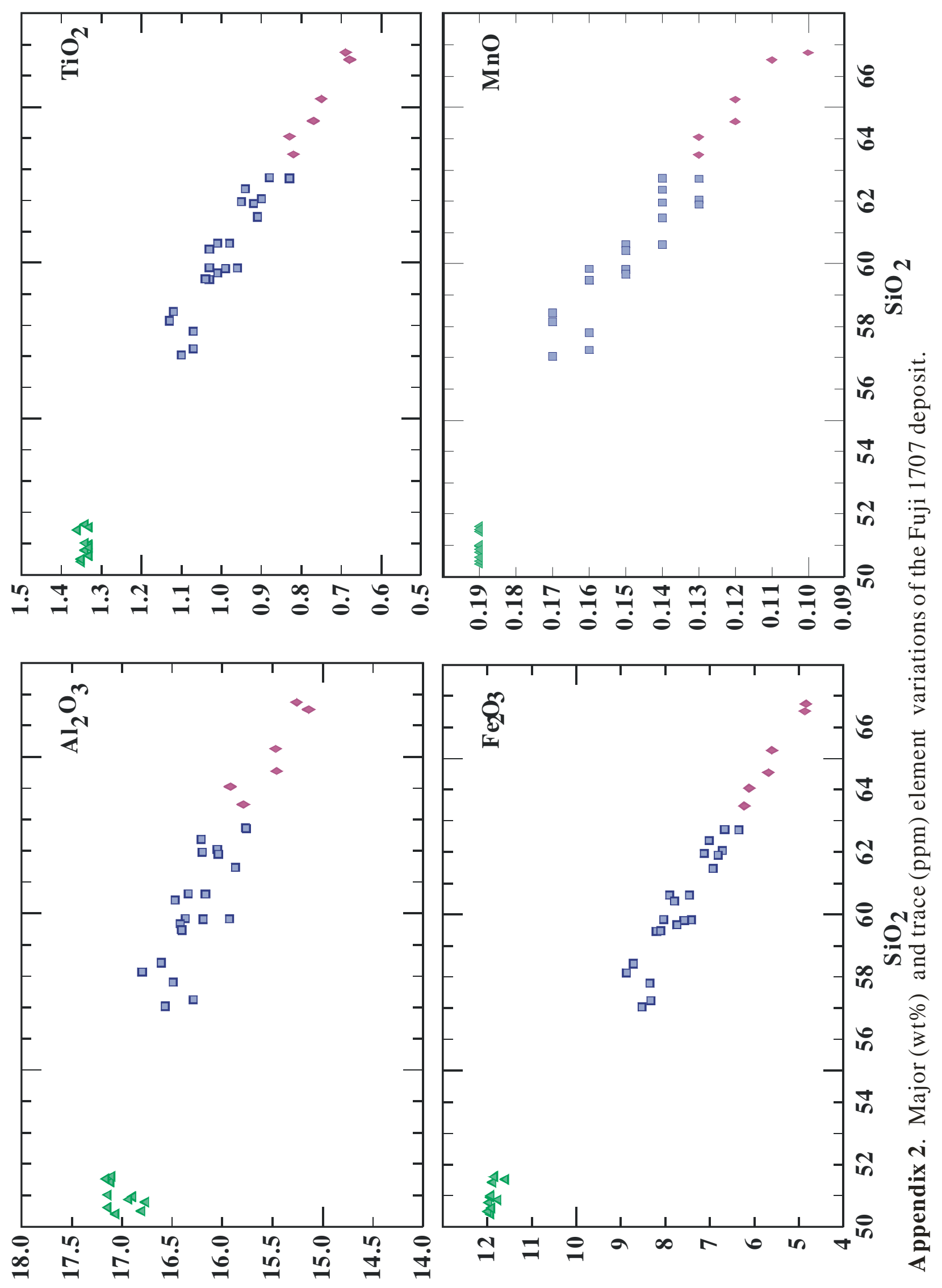



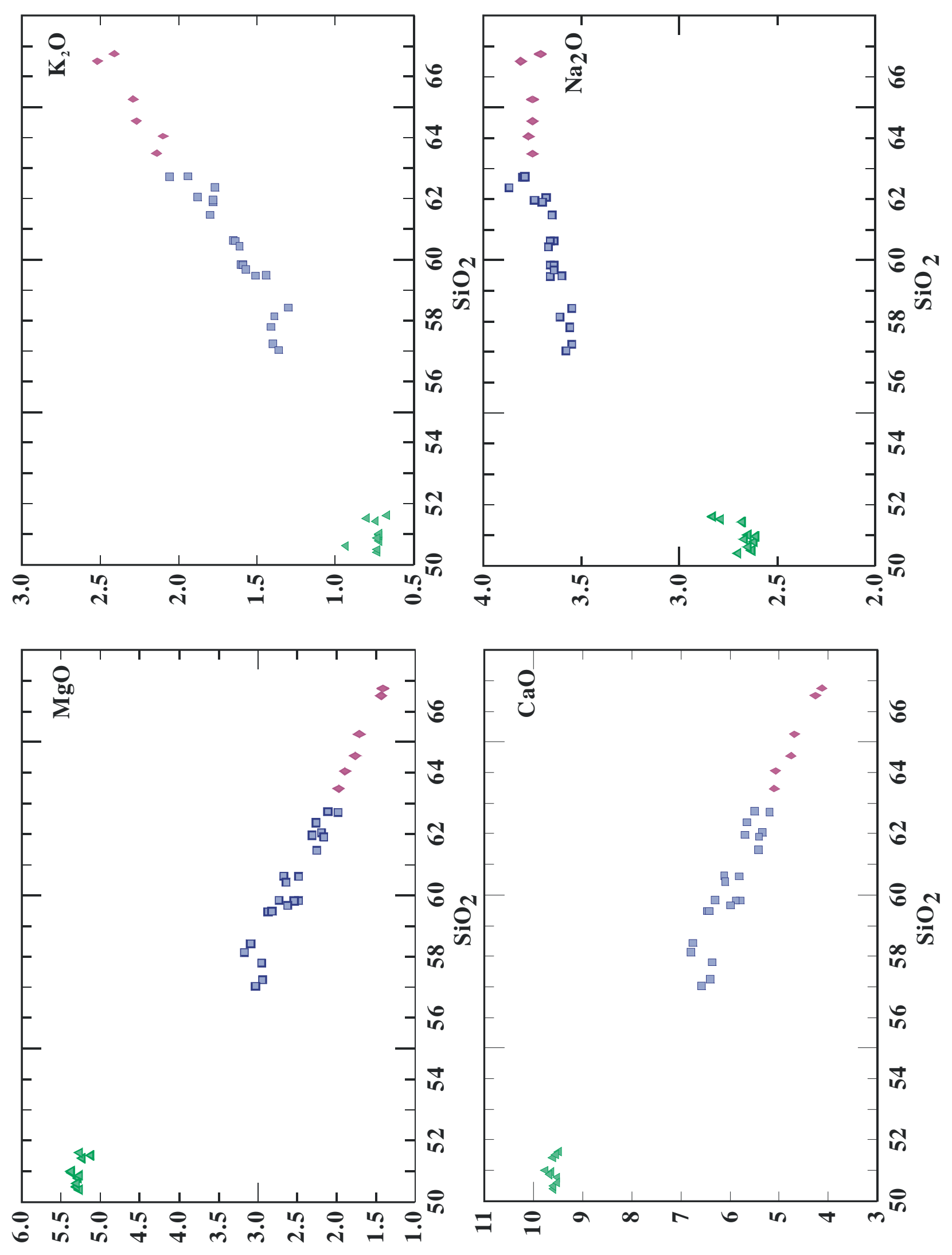

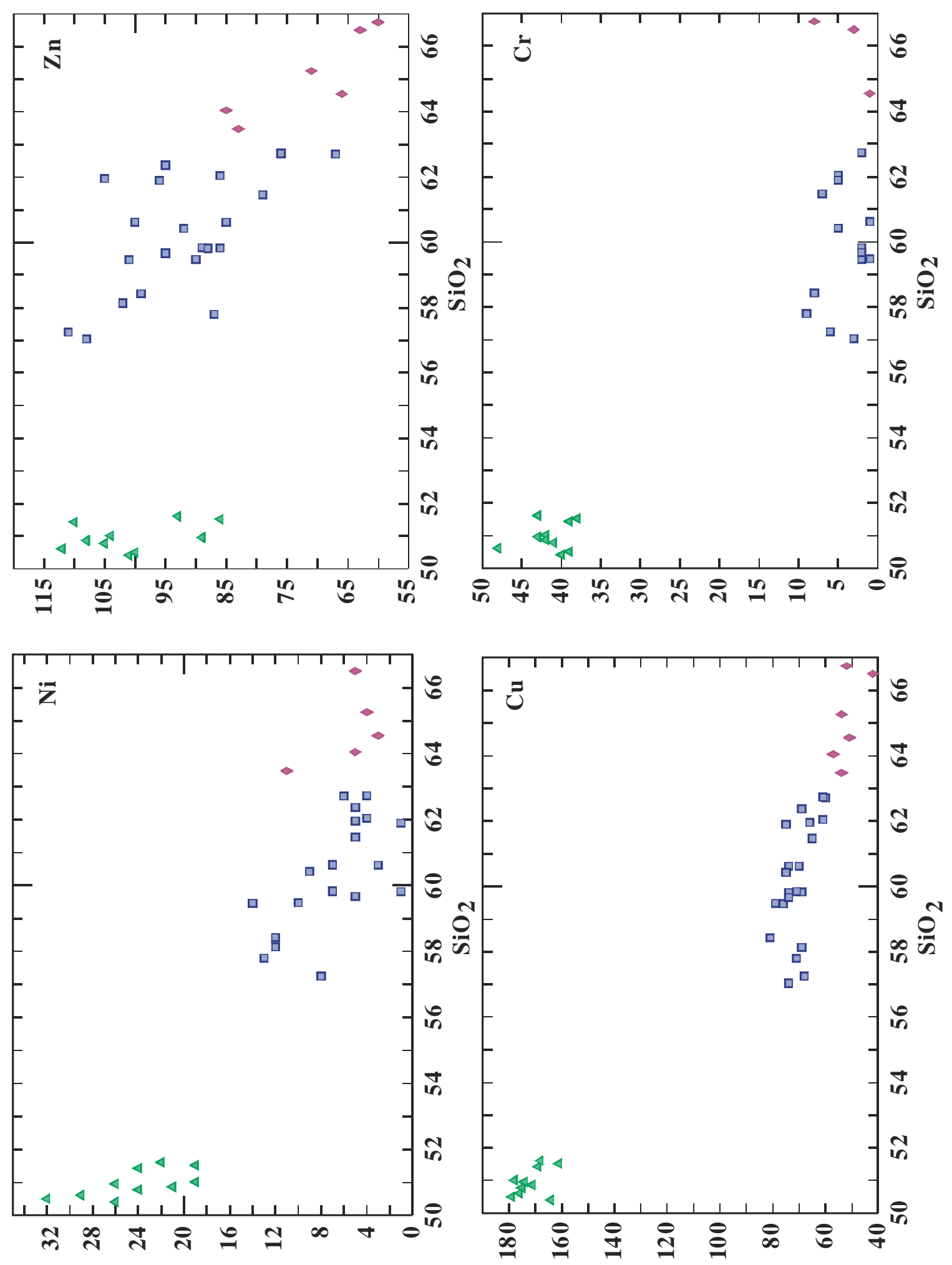

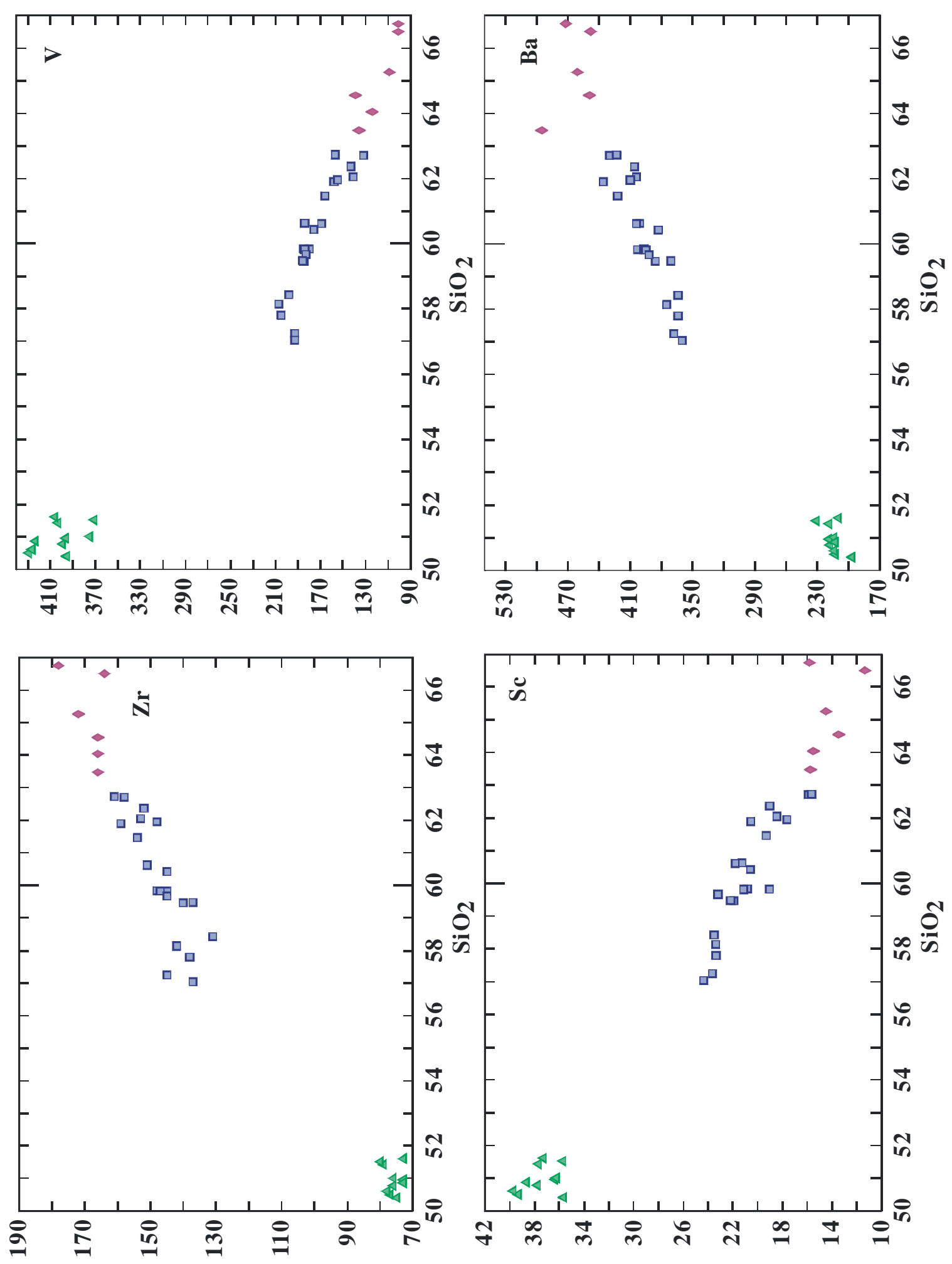

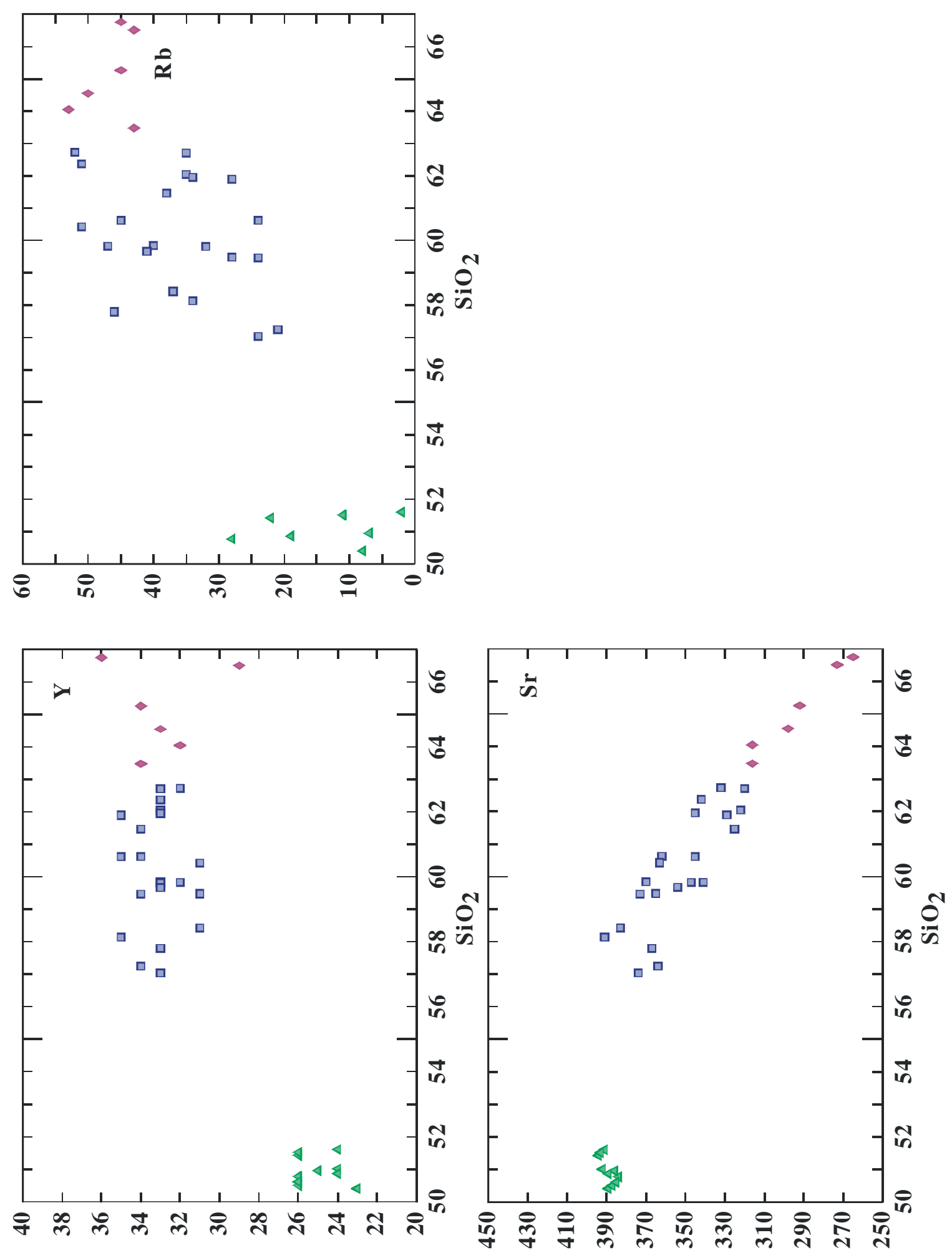


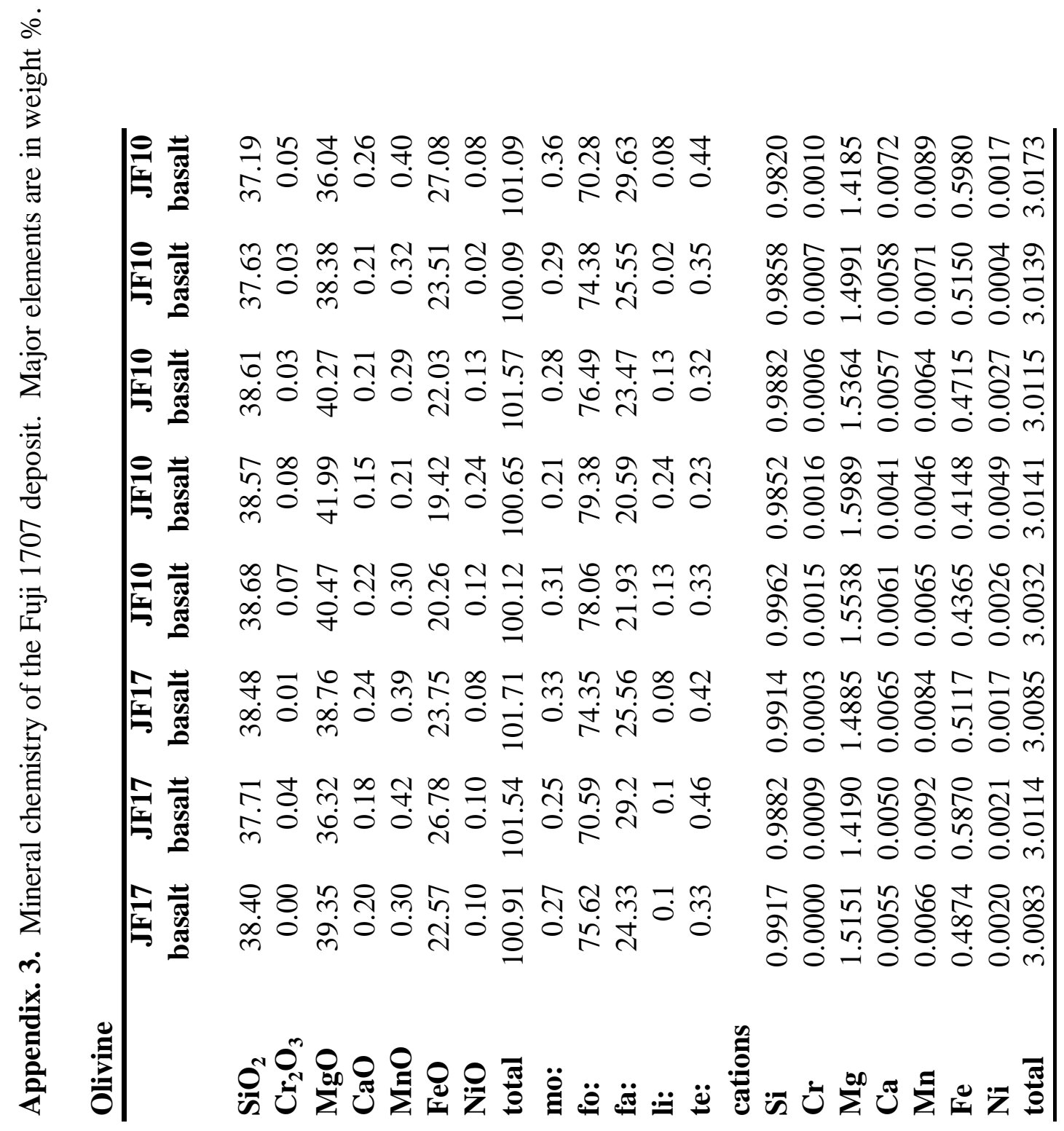




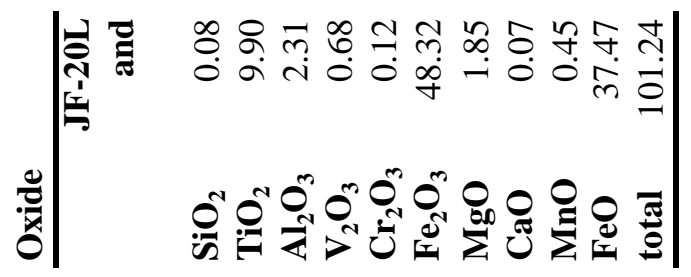

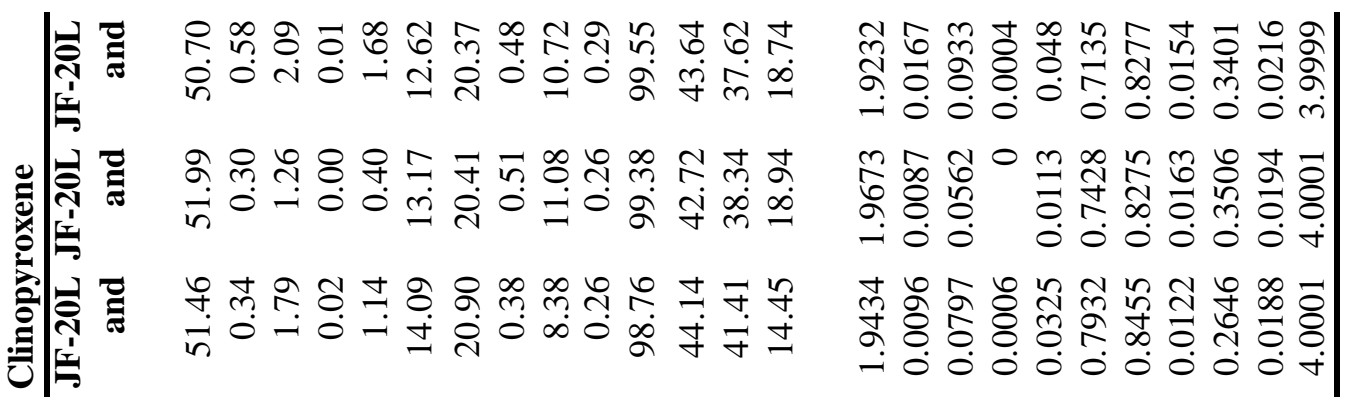

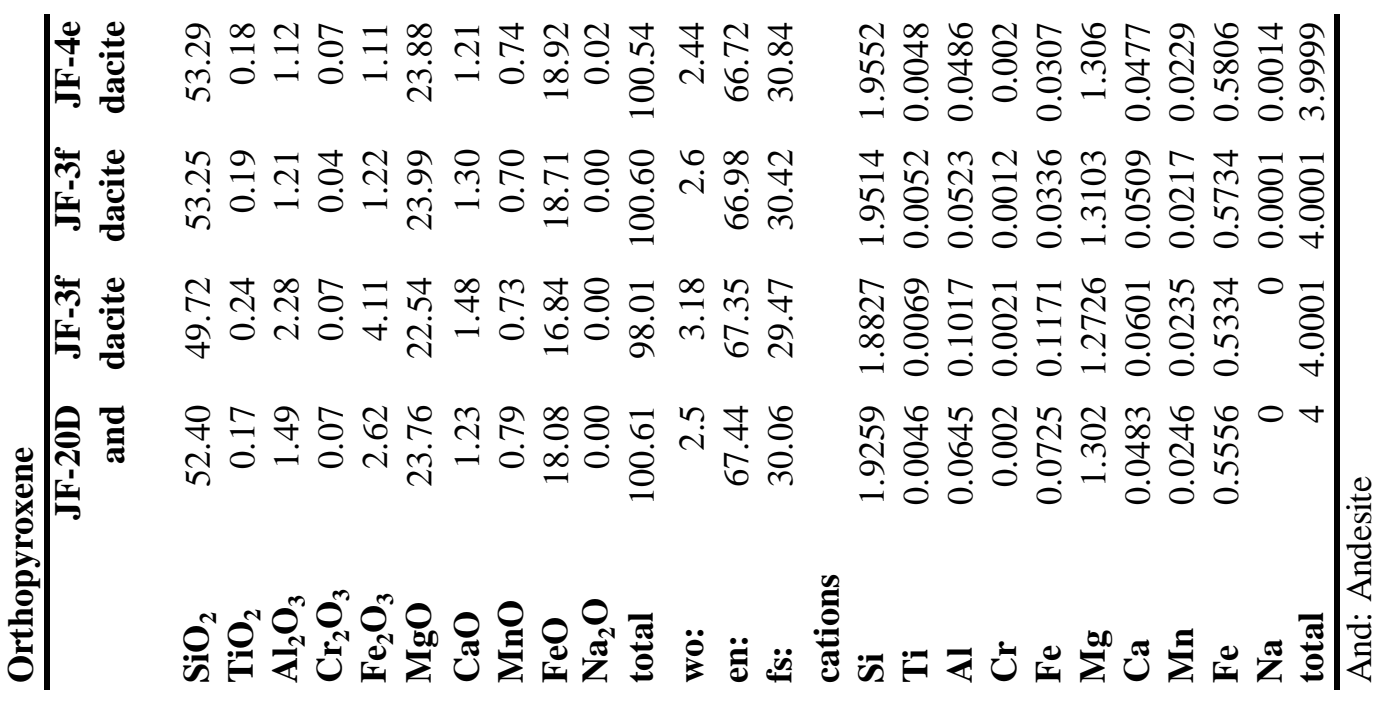




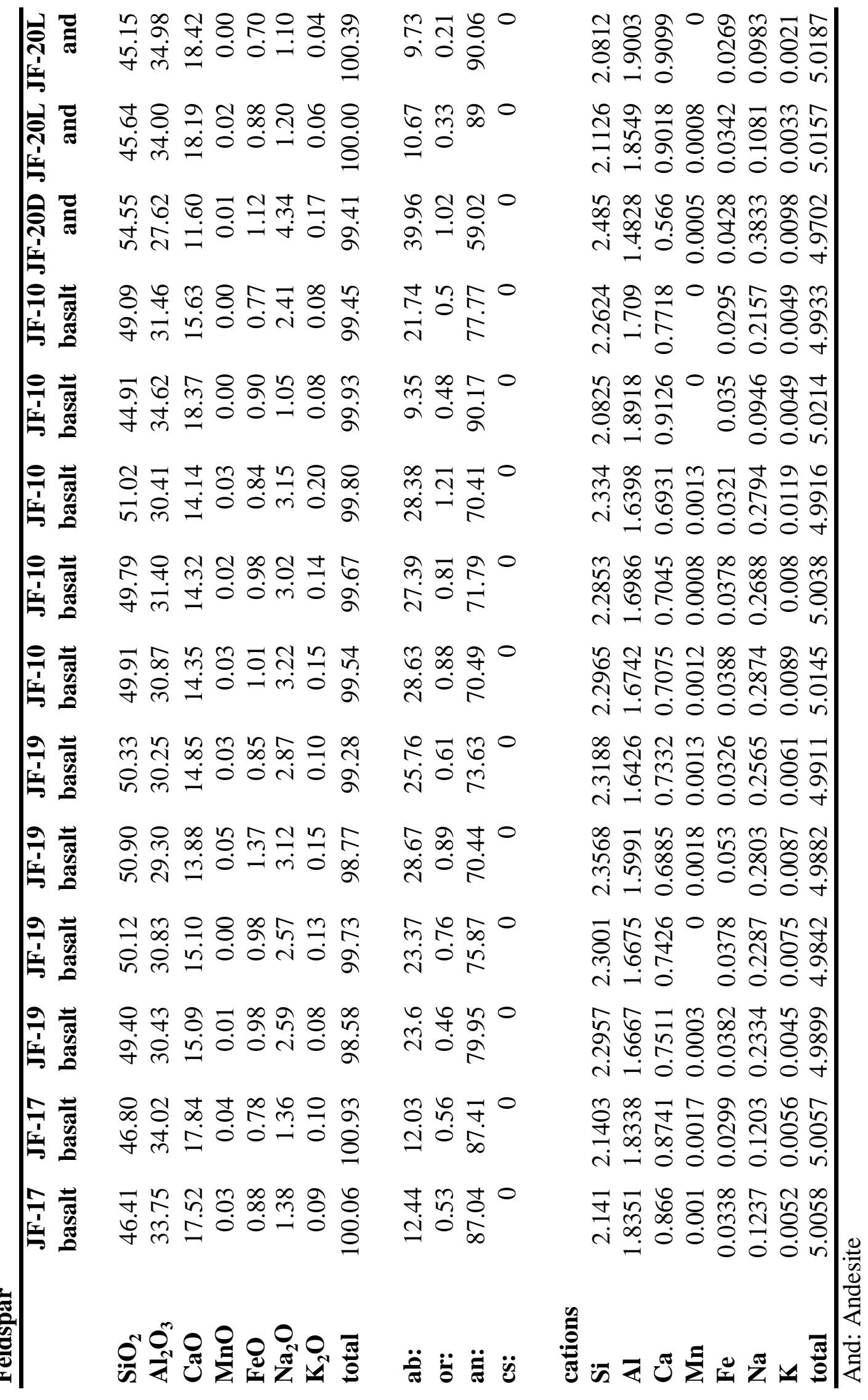




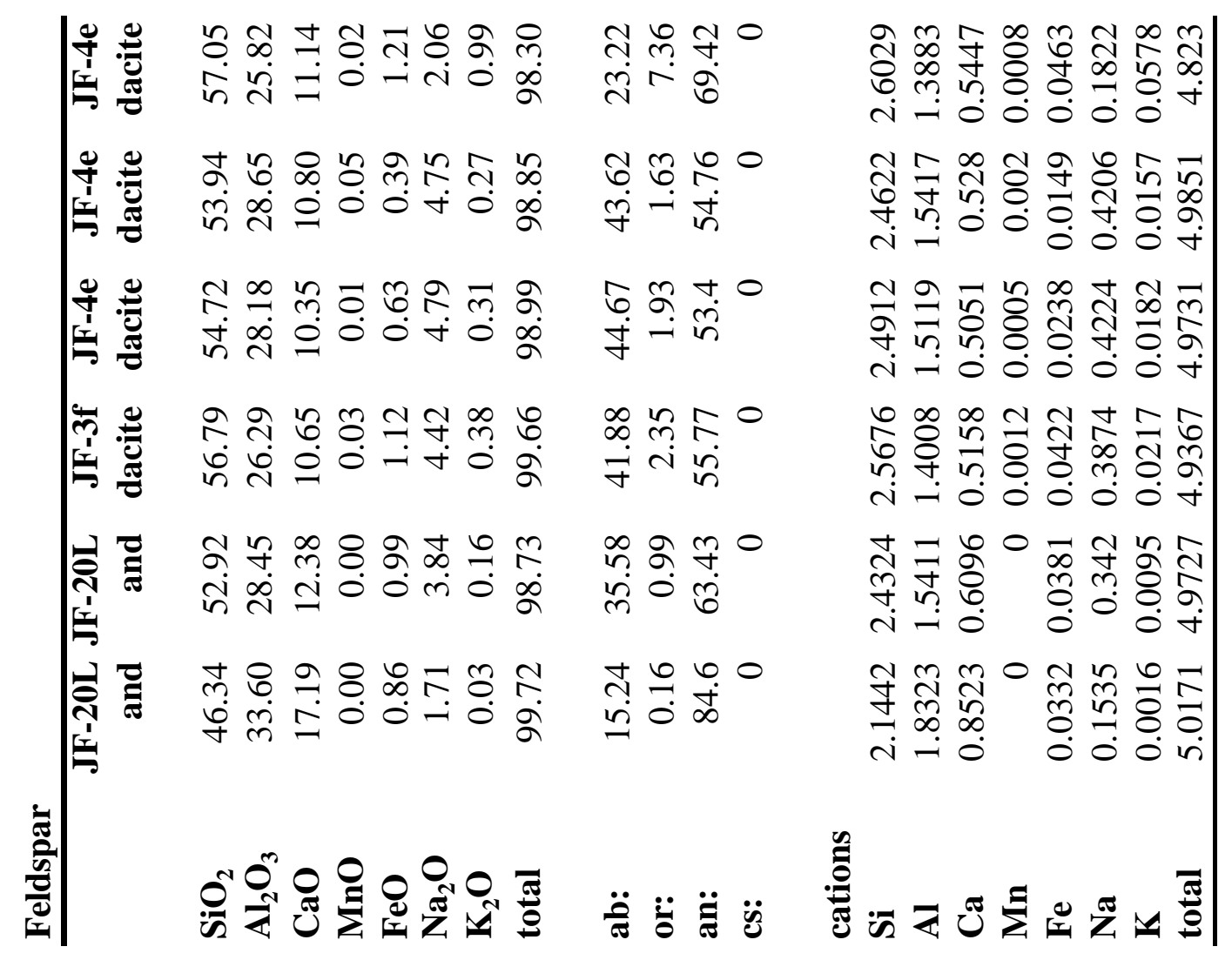


Appendix 4. Photomicrographs of the Fuji 1707 deposit. Photographs are taken either with plane polarized light (PP) or crossed polarized light (XP) with 4X, 10X or 20X magnification.

\section{Basalt}

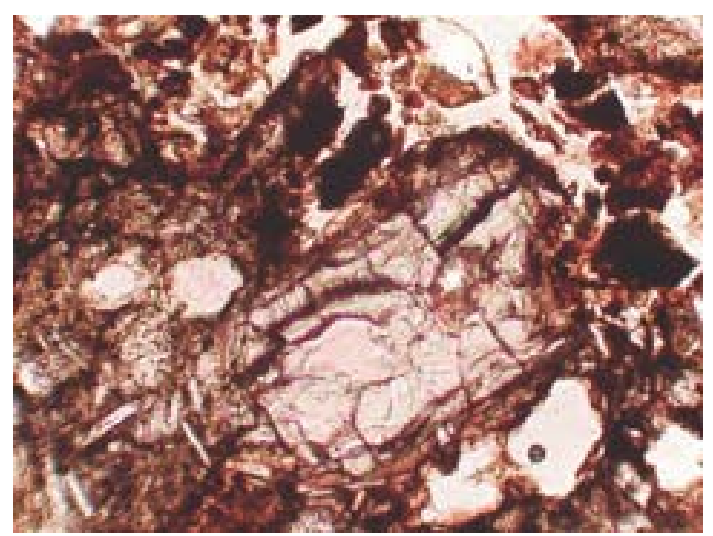

Olivine and oxide (PP/10X)

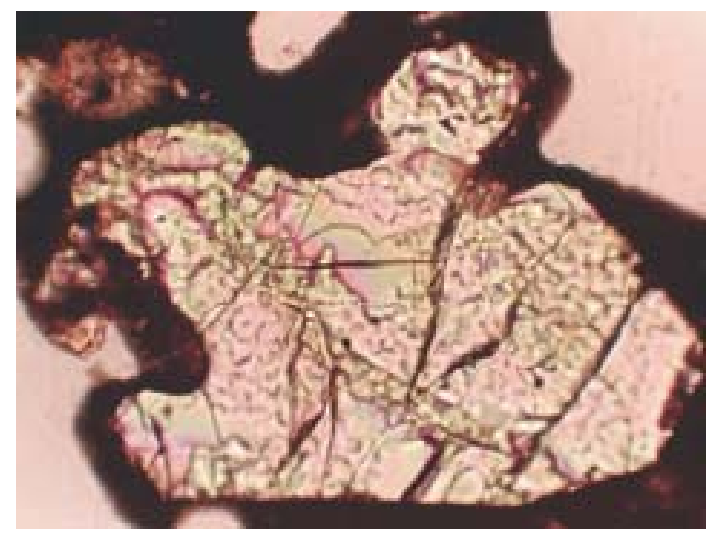

Resorbed olivine (PP/10X)

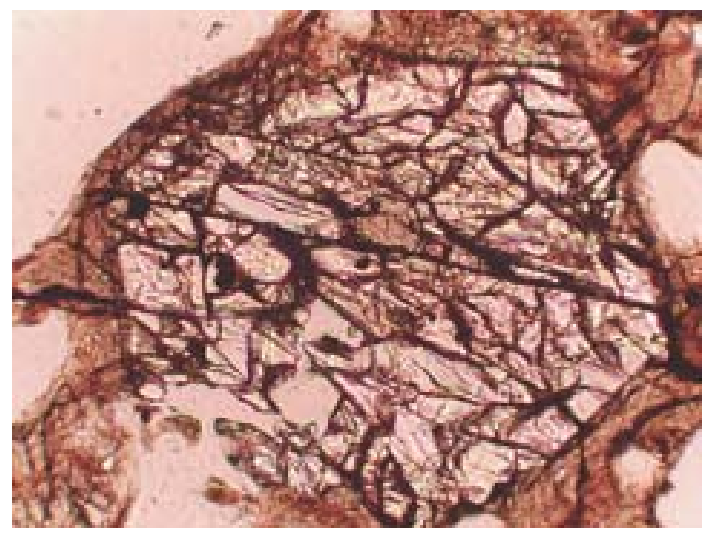

Euhedral olivine (PP/10X)

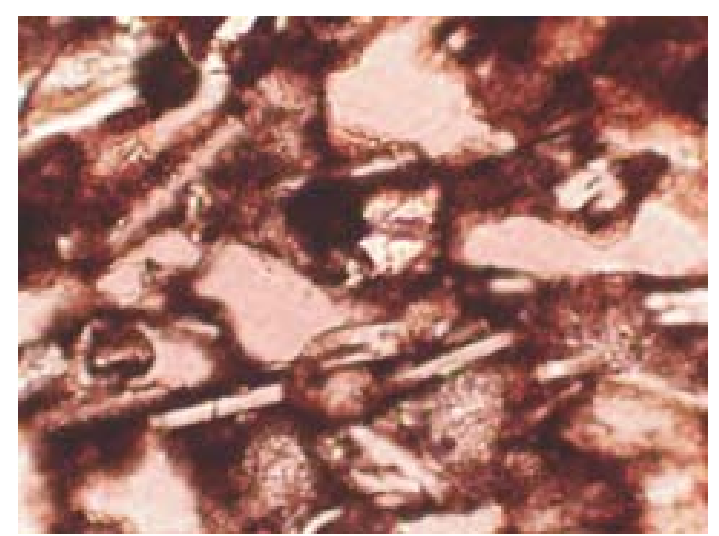

Augite and plagioclase (PP/20X)

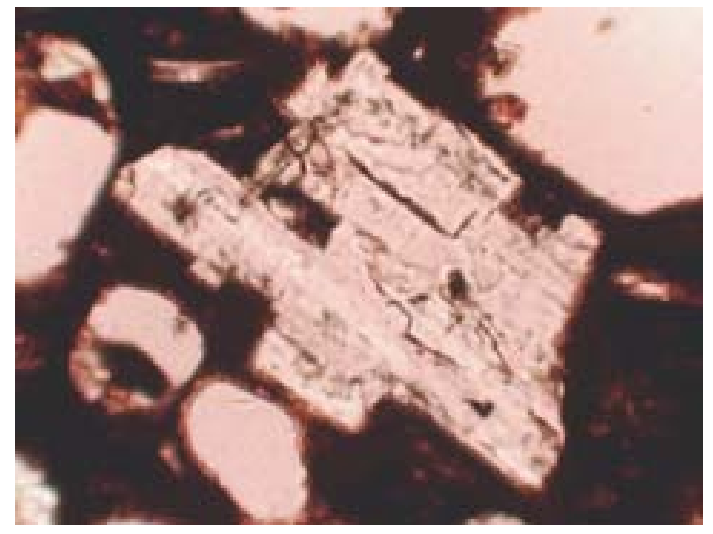

Euhedral Plagioclase (PP/10X)

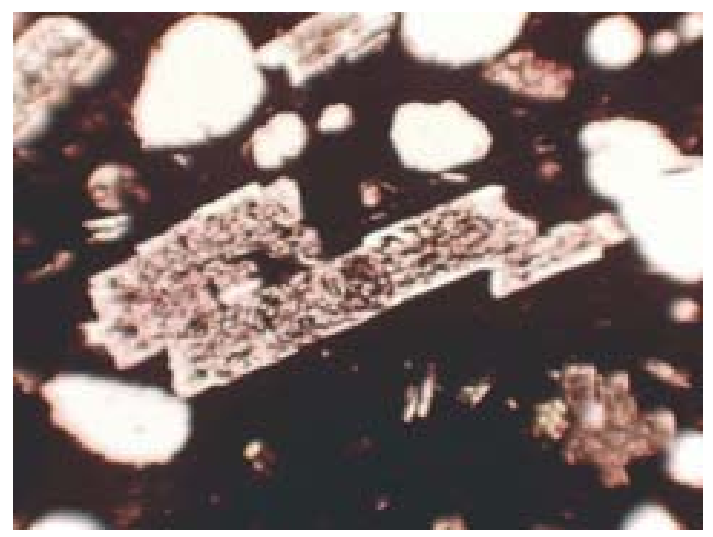

Resorbed Plagioclase (PP/10X) 


\section{Andesite}

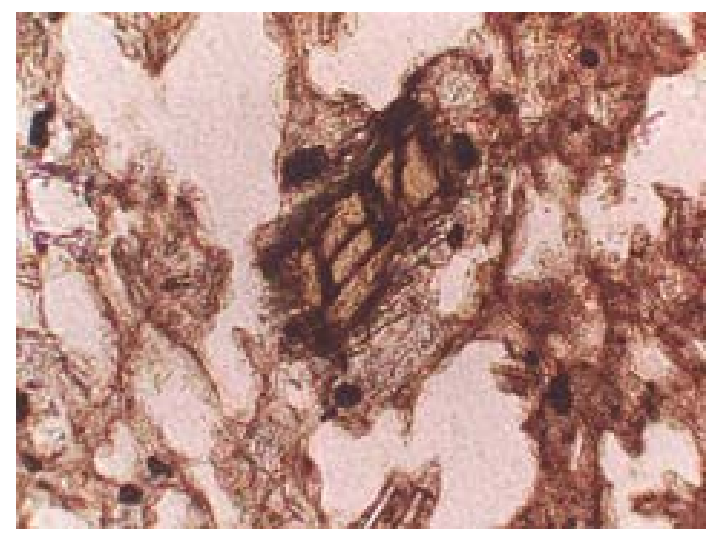

Hypersthene (PP/20X)

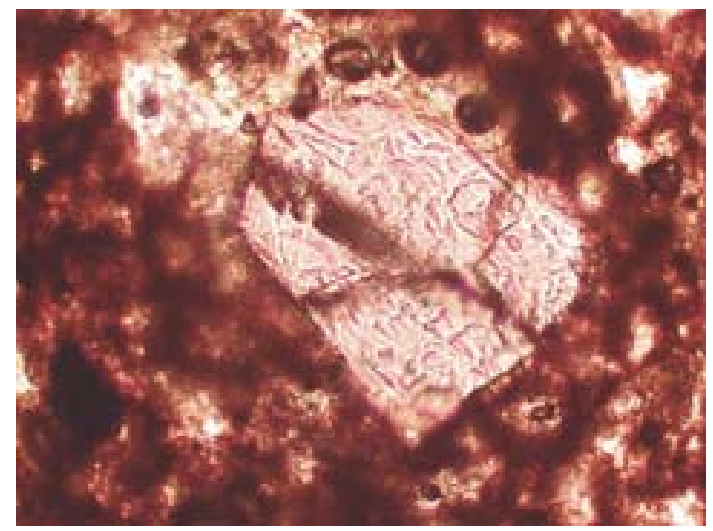

Hypersthene (PP/20X)

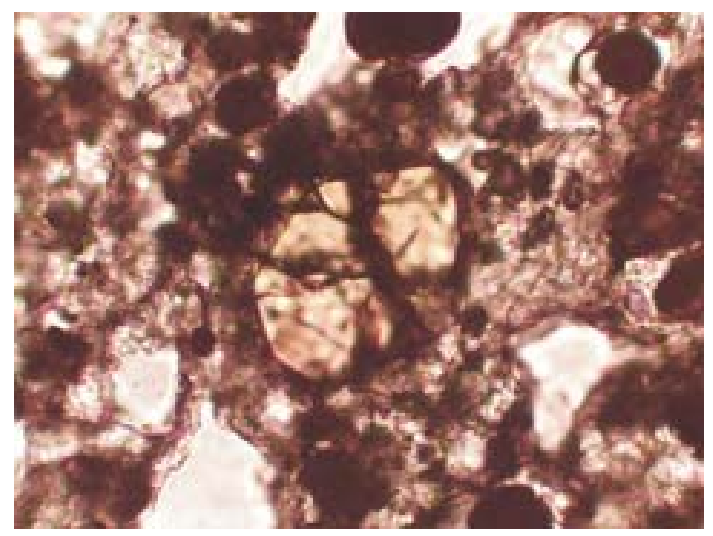

Augite (PP/20X)

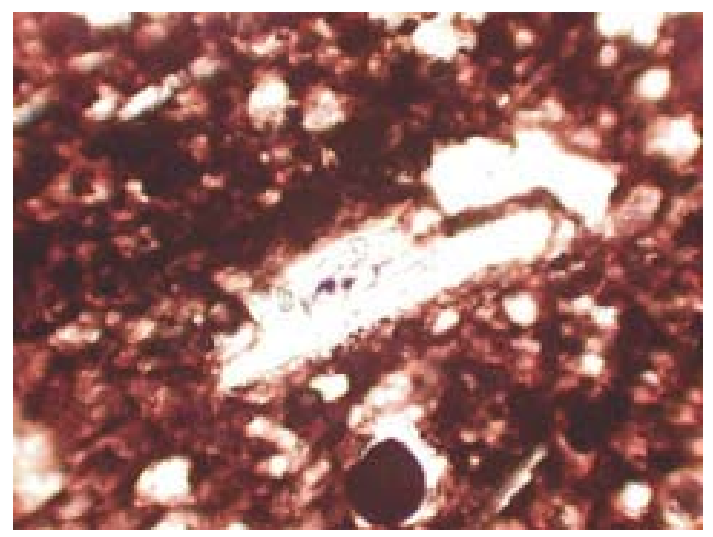

Plagioclase (PP/10X)

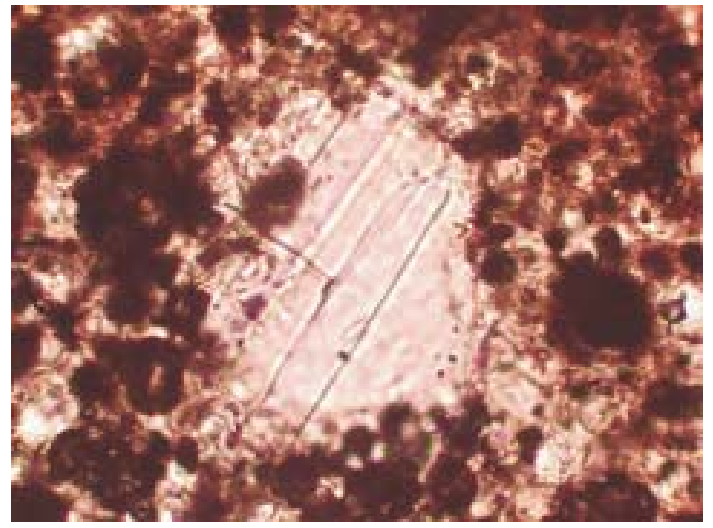

Plagioclase (PP/20X)

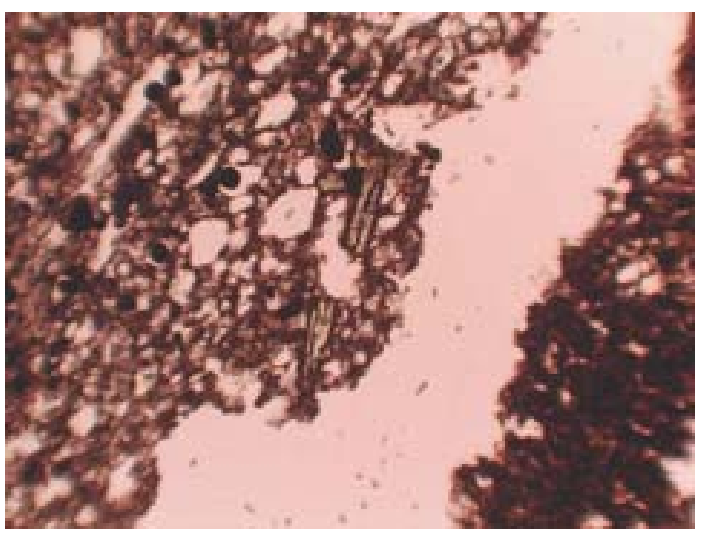

Hypersthene and oxide (PP/4X) 


\section{Dacite}

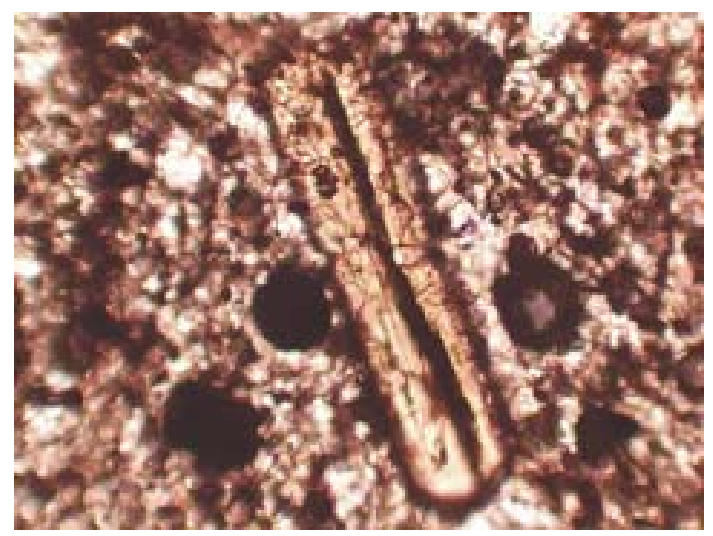

Hypersthene (PP/10X)

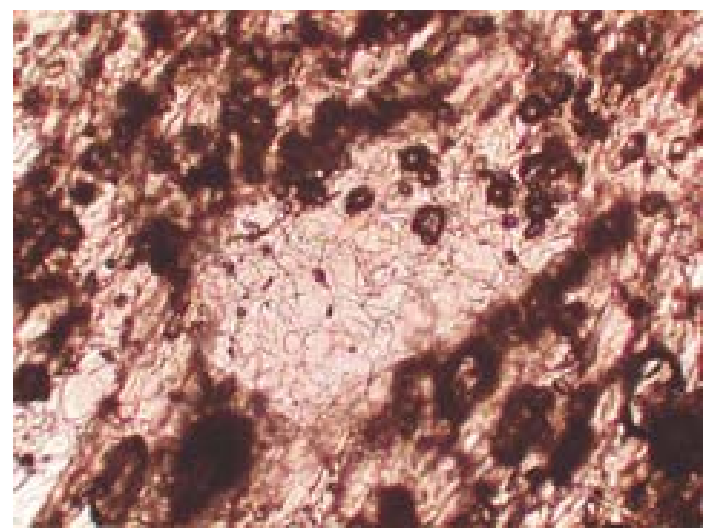

Plgioclase (PP/10X)

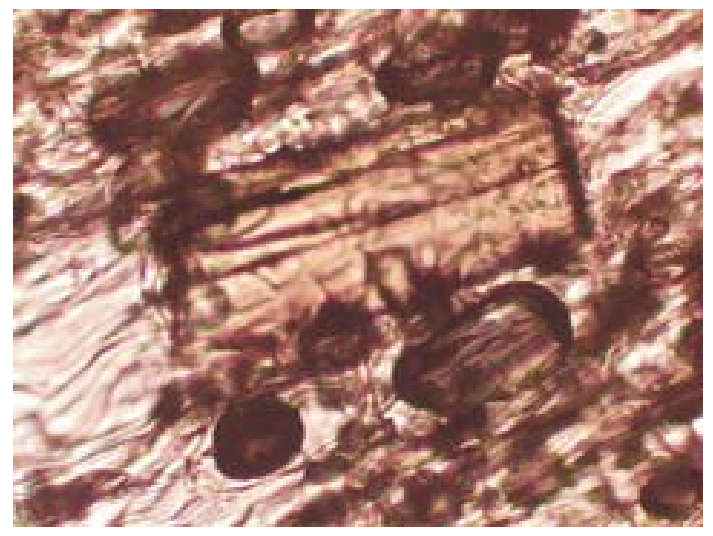

Hypersthene (PP/20X)

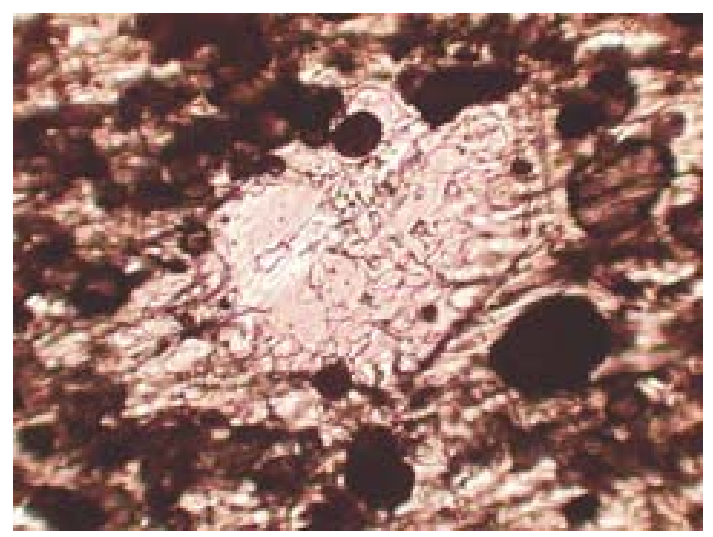

Augite (PP/10X)

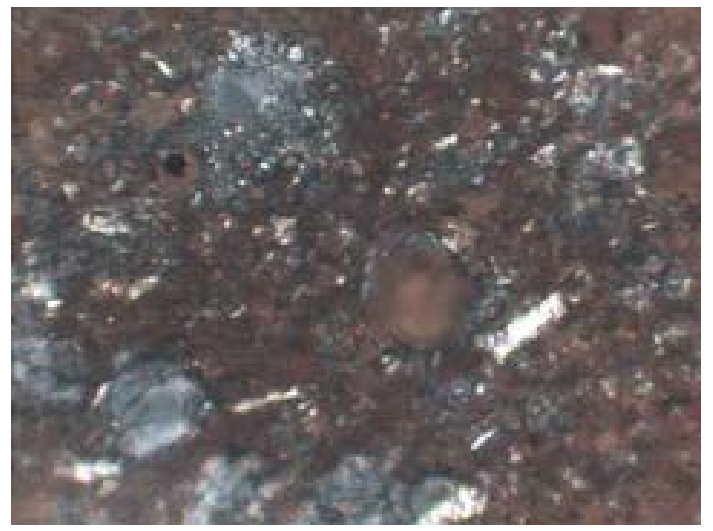

Plagioclase phenocrysts and microphenocrysts $(\mathrm{XP} / 4 \mathrm{X})$

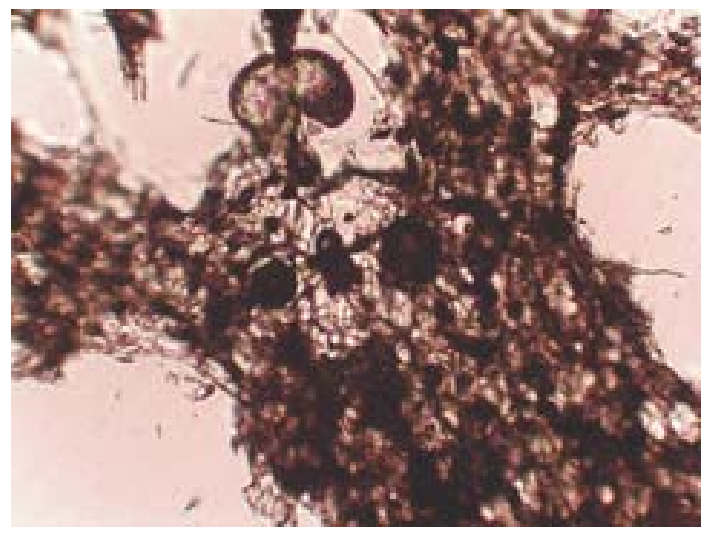

Hypersthene and oxide (PP/10X) 